\title{
Goizuetako azentu-hiztegia \\ An accent dictionary of Goizueta Basque
}

\author{
Oihana Lujanbio Begiristain
}

\begin{abstract}
The aim of this dictionary is to describe the accentual patterns of Goizueta Basque. This dictionary contains around 2,400 entries provided with accent marks. The selection of lexical items has been made on the basis of other dictionaries of northern Navarrese varieties.

In addition to the dictionary, this contribution includes an explanation of the rules and physical characteristics of the accent system of Goizueta Basque. For this purpose, we have summarized previous work on the word prosody of the Basque dialect of Goizueta and, in some cases, we have completed the description. In particular, we examine the prosodic properties of word groups, as well as variation found among age groups.

At the end, we sum up the most important contributions and conclusions of the work and offer an account of the main characteristics of the Goizueta accent system.
\end{abstract}

Keywords: Dictionary, accent, accent rules, word groups, variation.

\section{Laburpena}

Goizuetako azentuera deskribatu asmoz idatzi da azentu-hiztegi hau. 2.400 sarrera inguru dituen hiztegia da, Nafarroa iparraldean egindako beste hiztegi batzuk oinarri hartuta osatu dena.

Behin oinarri hori osatuta, Goizuetako azentu sistemari buruzko arau eta ezaugarri fisikoen azalpena egin da. Horretarako, orain arte Goizuetako azentuerari buruz egin diren deskribapenak laburtu dira eta horiei ekarpenen bat egin diegu ahal izan dugunean. Hitz taldeetan gertatzen dena aztertu da eta adinaren arabera ikusi diren aldaketa batzuen berri ere ematen du lan honek.

Bukaeran, laburpen modura lanaren ekarpen eta ondorio nagusiak biltzen dira eta Goizuetako azentu-sistemaren ezaugarri batzuk adierazi dira.

Hitz gakoak: Hiztegia, azentua, azentu-arauak, hitz-taldeak, aldakortasuna. 


\section{Sarrera*}

Goizuetako hizkerak duen bereizgarri nagusietakoa da azentuera eta bertakoei askotan esaten digute kantari hitz egiten dugula. Hain berezia izan arren, berari buruzko ikerketak gutxi dira.

Lan hau idaztea erabakitzean, Goizuetako gazte eta helduen arteko azentuzko diferentziarik ba ote zegoen aztertzea pentsatu nuen. Baina gaian sakontzen hastean, aurrena azentu sistema bera argitu behar zela konturatu nintzen. Alegia, aurrena azentu sistema bera ulertu behar nuela, bere aldaketa aztertu ahal izateko. Beraz, lan honen helburu nagusia hori izan da: Goizuetako azentuera deskribatzea, hitz solteen azentueratik hasiz.

Horregatik ekin nion azentu-hiztegia osatzeari. 2. atalean dago, oso-osorik. 2.400 sarrera inguru dituen hiztegia, besteak beste, 2008an egindako 20 elkarrizketetako materialak eta galdetutakoek emandako erantzunek osatu dute. Nire eskerrik beroenak eman nahi dizkiet lagundu nauten guztiei. Hemen grabazio horien aukeraketa bat egin eta bi hiztunekin izandako elkarrizketen zati batzuk idatzi dira, 3. atalean ikusi ahal den bezala. Behin oinarri hori osatuta, Goizuetako azentu sistemari buruzko arau eta ezaugarri fisikoez hitz egin da 4. eta 5. ataletan. Ondoren, hitz talde batzuetan gertatzen dena aztertu dut 6. atalean, eta, bukatzeko, adinaren arabera nabaritu ditudan aldaketa batzuen berri eman da 7.ean.

Azkenean beraz, Patxi Juaristiren sailkapenaren arabera, ikerketa esploratzailea da honakoa. Izan ere, bere hitzetan, «ikerketa esploratzaileetan, fenomenoen ezagutza orokorra lortu nahi da. Helburua gehiago da balizko azalpenak aurkitzea, hipotesi zehatzak frogatzea baino» (2003: 34).

Ikerketa hauetan, gaia ezagutzen ez denez, normalean ez da aurretiaz hipotesirik egiten. Dena den, lana egiten hasterakoan, buruan hipotesi batzuk banituen:

1. Goizuetako hizkeran goranzko eta beheranzko azentuak daude eta «bereizleak» dira; azentuak bi hitz bereizteko balio du. Eta hiztunek ere azentu batetik besterako aldea nabaritzen dute.

2. Aldakortasuna, gazte eta helduen artean, hitz eta esamolde zehatz batzuetan nabari da; hitz berriez gain, aditz (zahar) batzuetan ere. Bestalde, zaharrek beheko azentutik gorakora dagoen distantzia handiagoa eginez hitz egiten dute eta azentu «esageratuago» bat dute, orokorrean.

Lan hau ez da bi hipotesi hauek balidatzeko ikerketa izan, baina ditudan datuekin, biak baieztatuko nituzke. Hemengo lana Goizuetako azentuera deskribatzea izan da eta, orain arte egindakoa kontuan hartuz, proposamen berriak egitea. Atalez atal, egoera deskribatzearekin batera, arauak eta orokortasunak ematen saiatu naiz. Laburtuz, hau da ondorio nagusia:

Goizuetako hizkerako azentuera nagusia [+2] eta goranzkoa da. Hau da, ezkerretik hasi eta 2. silaban azentuatzen dira Goizuetako hitz gehienak. Horretaz gain, azentu horrek doinu diferenteak izan ditzake: goranzkoa eta beheranzkoa. Goranzkoa da ohikoena

* Artikulu hau EHUko Euskara eta Eleaniztasuneko Errektoreordetzako euskarazko tesia egiteko dirulaguntzari eta Espainiako Gobernuko Ekonomia eta Lehiakortasun Ministerioko dirulaguntzari (FFI2012-33190 proiektua) esker prestatu ahal izan dut. 
eta beheranzkoa bereziena. Horregatik diogu beheranzko azentua azentu markatua dela. Hain zuzen ere, beheranzko azentu hori daramaten hitz gehienek badute berezitasunen bat: mailegu berriak, izen propioak, plurala, galdegaia, silaba galeraren bat izan duten hitzak, hitz elkartuak edo silababakarrak izan ohi dira beheranzko azentua daramatenak.

Gauza batzuk argitu dira, baina, argitzearekin batera, galdera berriak sortu ere bai. J. I. Hualdek Goizuetako azentu sistemak suedierarenarekin antzekotasuna duela esaten du, baita ezaugarri honetan ere: «suedieraren azentu sistema nahiko konplexua bada ere, datuak kontuz aztertuz gero, joerak eta azpierregulartasunak aurkitzen ditugu» (Hualde 1997: 53).

Berez sistema konplexua da eta horri aldakortasunerako beste faktore bat gehitu behar zaio: komunikazio-egoera. Goizuetako azentuera arauetara ekarri arren, hizkera komunikatzeko tresna da. Eta komunikazio tresna orok komunikazio-egoerara egokitu behar du, tresna ona izango bada. Goizuetako azentuera ez da salbuespena.

Guztiok aintzat hartzen ditugun arau nagusi batzuk daude, baina goizuetar bakoitzak bere erritmo eta doinua dauka. Unean unean erabakitzen du zenbateko intentsitate eta doinu gorakada edo beherakada eman bere hizkera biziari. Baina denak pentagrama berean, muga berberen artean eta antzeko gorabeherekin gabiltza, normalean. Lan honetan doinu horren berri ematen asmatu izanen al da! Horretan saiatu dira ikertzaile honen belarri, buru eta gainerako tresna guztiak.

\section{Goizuetako azentu-hiztegia}

\subsection{Helburuak}

Lan honen helburua Goizuetako azentua eta doinua ikertzea da. Azentua eta doinua esatean zer adierazi nahi dugun zehazteko definizio batzuk erabili ditugu. Orokorrenetik hasiz, Lur hiztegi-entziklopedikoak definizio hauek ematen ditu:

Azentua: hitz egitean hots jakin bati ingurukoei buruz ezartzen zaion ahoskatze gehiagotasun, pisu indar... handiagoa. dena.

Doinua: ahotsaren tonu aldaketen segida, hizkera bakoitzaren ezaugarri gertatzen

Euskararen azentuerak liburuan (Hualde 1997: 5), honela definitzen da azentua:

Azentua eremu edo unitate bateko silaba bati ematen zaion prominentzia edo nagusitasun fonologikoa dela esan dezakegu. Azentua ez da zerbait absolutua, erlatiboa baizik. Edo beste hitz batzuekin esateko, ez dago silaba azentudunik azentugaberik gabe. Silaba bat azentuduna den jakiteko, eremu bereko beste silabekin konparatu behar dugu.

Beste modu batera esanda, azentuak silaba bat besteen gainetik nabarmentzen du, hitzen silaba nagusia markatzen du. Doinua berriz, silaben musikalitatea da, ahots korden dardarak eragindako tonu diferenteek sortua. Biak batera aztertu dira, Goizuetako hizkeran biak direlako ezaugarri bereizgarri. Silaba nagusia hitzaren silaba diferentetan egon daiteke. Adibidez, até ('ate') eta áte ('ahate'). Aldi berean, silaba bakoitzean bi doinu diferente egon daitezke. Adibidez, bóta ('oinetakoa') eta bòta ('jaurti'). Bi diferentzia hauek bereizten dituzten hitz pareak ere baditugu. Esaterako, basó ('baso') eta bàso ('edalontzi'). Horrelako kontrasteak dituzten bikote eta taldeak hiztegian zehar markatuak daude, laukietan bilduta. 
Fenomeno horri buruzko informazio zehatzagoa Hualde, Lujanbio eta Torreiraren artikuluan dago (2008: 1). Era berean, artikulu honetan Goizuetako azentuerari buruzko zehaztasun gehiago ematen dira. Zehaztasun horien artean, Goizuetan azentua Bizkaia eta Gipuzkoako hizkeretan baino iraupen eta intentsitate handiagoren bidez gauzatzen dela zehazten da (2008: 1).

Azentua eta doinua definituta, errazagoa da azentuera zeri deitzen diogun azaltzea: azentuera, azentua eta doinua biltzen dituen hitza da. Bide batez, azentua ' eta 'ikurrak adierazteko ere erabili dira.

Hitzetara mugatu da, nagusiki, gure azterketa, hitzek bakarrik daudenean erakusten duten sistemaren azterketara. Hortik abiatu nahi izan dugu konplexua iruditzen zitzaigun sistema argitzeko ibilbidea. Horretarako osatu da hiztegi hau, azentua eta doinua aztertzeko oinarria edukitzeko. Dena den, lanean zehar, oso presente izan dugu esaldi mailako prosodia, hau da, hitzek kontestuan dituzten aldaketak. Ohartu gara, batzuetan, esaldi mailako prosodiaren arabera, doinu ezberdina hartzen dutela hitzek. Horregatik, singularrean eta modu neutroan esaten ditugunean duten azentuera adierazten dute hiztegian zerrendatutako hitzek. Prosodiaren arabera doinu aldakorra erakusten dutenak * ikurrarekin markatu ditugu. Aldakorra diogunean zera esan nahi dugu: hitzak esaldian duenaren arabera, azentuaren doinua aldatzen dela. Honen azalpen zehatzagoa 2.2.2 Hitzen aurkezpena atalean eman da.

Hiztegiaren helburua, Goizuetako azentua eta doinua ikertzeko oinarri bat edukitzea da, corpusa bildu eta zehaztea. Lanaren lehen zatian hiztegia egiten aritu gara, Goizuetako azentua eta doinua ikertzeko oinarria izango zen hiztegia. Beraz, hiztegi hau azentuera ikertzeko hiztegia da eta, ondorioz, ez ditu semantika hiztegietako ezaugarri berberak. Hurrengo atalean azaltzen dira hiztegi honen ezaugarriak.

Hiztegiak gaur egun Goizuetan erabiltzen den hizkeraren berri eman nahi du. Bukatzeko, hiztegi arruntetan sartzen diren baino mailegu gehiago zergatik sartu diren adierazi nahi dugu. Hiztegi honetan, gaur egun erabiltzen diren hitzen azentu eta doinua bildu nahi izan da. Hori aztertzeko dugun modu bakarra da, testuetatik gauza frogagarri gutxi atera baitezakegu. Aztergaia mugatua izanik, normalean Goizuetako hiztunek erabiltzen dituzten hitzak bildu nahi izan dira, horiek euskal jatorrikoak, aspaldi mailegatutakoak edo mailegatu berriak izan. Horregatik, benèno, dezísio, làmina edo lejì bezalako hitzak aurki daitezke osatutako hitz zerrendan. Gainera, hitz berri horiek jasoz eta gaur egungo mailegatzeak dituen ezaugarriei erreparatuz, gure hizkeran gertatzen ari diren aldaketak azter ditzakegu.

\subsection{Ezaugarriak}

\subsubsection{Hitzen aukeraketa}

Pello Salabururen Baztango mintzoa: gramatika eta hiztegia (2005) liburuko hiztegia dago lan honen oinarrian. Hiztegi honen hitz zerrendatik Goizuetan erabiltzen direnak hartu dira eta Goizuetako hizketan duten azentuera markatu zaie. Azentuera markatzerako orduan, ' eta ' ikurrak erabili dira. Geroago sakonago aztertuko badugu ere, ' ikurrak goranzko doinua adierazten du eta 'ikurrak berriz, beheranzkoa. ' azentua, akutu deitzen da eta ' grabea. 
Corpus hau osatzeko, iturri hauek erabili dira:

Mikel Olanoren hiztegia. Liburuaren izenburu osoa hau da: Aio, Leitze! Leitzako euskararen hiztegia. Etnografia, corpusa, dialektologia (2005).

2008ko martxo eta apirilean egindako grabaketetatik ateratako hitzak: 10 emakume eta 10 gizonen hizketa grabatu da ( 15 minutu inguru). Testu horretatik ateratako hiztegia oinarrian zegoenari gehitu zaio.

Ikertzaileek faltan sumatutako hitzak. Arrunt oinarrizkoak zirelako-edo, ikertzaileek faltan zirela nabaritu dituzten hitzak ere sartzen joan gara. Tartean, izen propio batzuk daude: inguruko herri-izenena (izen propioak nola ahoskatzen diren jakiteko) eta izen propio batzuk (doinuagatik bereizten diren hitz parea osatzeko).

Goizueta inguruko hitz bereziak. Lan honetan, hitz horiek ere bildu beharra ikusi da. Bilaketa sakon eta zehatza egin ez den arren, otutakoak eta inguruan galdetu eta bildutakoak sartu dira. Zerrenda ttikia da, ordea, eta hiztegian barrena ez galtzeko, aparteko zerrenda batean daude, bukaeran.

Koldo Zuazoren Mailopeko euskara liburuko hiztegia. Azkenik, lan honetako hitzen zerrenda ere erabili da gure hiztegia osatzeko.

Iturri hauetako hitz asko ez dira sartu, ordea. Goizuetako hizkeran erabiltzen direnak sartu dira, baina filtro nagusi hau erabilita: Goizuetako hiztegiaren egilea gaztea eta herritarra izanik, aipatutako bi hiztegietako hitz asko ez ditu ezagutzen, eta ondorioz, hitz horien azentuera ezta ere. Horregatik, ezagutzen ez dituen hitzak ez ditu sartu. Hala ere, zalantza sortarazten zuten hitzen zerrenda osatu du (200 hitz ingurukoa) eta elkarrizketatuei galdetu dizkie. Beraz, gaur den egunean Goizuetako gazte batek egunerokoan entzuten dituen hitzek osatzen dute corpusaren zatia.

\subsubsection{Hitzen aurkezpena}

Aurren-aurrena, kontuan hartu behar da azentuera aztertzeko hiztegia dela hau. Horregatik, hiztegian dauden sarrerak eta beren azalpenak horretara bideratuak daude. Azentueraren ikerketarako baliagarri iruditu ez zaizkigun ohar eta azalpenak lan honetatik kanpo gelditu dira. Hitzen aurkezpena ematerakoan, egitura hau erabili dugu:

hítza azèntuarekin (euskara batuko forma) kategoria. gaztelaniarako itzulpena. Adibidez: beláso (belar-soro) iz. pradera.

Segidan, hitz sarrerako elementu bakoitzaren azalpena emanen dugu.

Hitza azèntuárekin. Azentu nagusia daraman silabari azentu ikurra paratu zaio. Ikur hau bi modutakoa izan daiteke, duen doinuaren arabera:

- ': goranzko doinua duenean. Honek, hitzaren azentu nagusiak hitzaren doinu altuena daramala adierazten du, akutuena (agudoena).

- `: beheranzko doinua duenean. Honek, hitzaren azentu nagusiak hitzaren doinu baxuena daramala adierazten du, grabeena. Hitz egiterakoan, beti ez da beherakada nabaria entzuten, batzuetan tonu laua mantentzen dela nabaritu dugu. 
Normalean, azentu bakarra markatu dugu. Hitz luze eta konposatuetan, ordea, bi azentu nagusi nabaritzen ditugu. Horrelakoetan biak adierazi dira.

Euskara batuko forma. Hitza euskara batuan erabiltzen den forman eman da, parentesi artean. Euskara batuan, baina Goizuetan erabiltzen den forma horretatik hurbilen dagoena. Antzeko formarik ez dagoenetan eta euskara batuan ordain egokirik aurkitu ez den kasuetan, euskara batuan onartua ez dagoen forma idatzi da. Forma onartugabea dela adierazteko, kurtsibaz eman da. Ordain egokia aurkitu denetan, euskara batuko aldaera eman da, Goizuetako formatik asko urrutiratzen bada ere. Honela, euskara batuan Goizuetako sarrerarentzat ordain antzekorik ez dauden kasuak erraz identifikatuko ditugu eta, alderantziz, Goizuetako hitza euskara batuan zein kasutan (askotan) dagoen onartua ikusiko dugu.

Kategoria. Kategoria hauetako hitzak sartu ditugu: izenak, adjektiboak, aditzak, adberbioak, zenbatzaileak, juntagailuak, interjekzioak eta izenordainak. Honakoak dira kategoria horiek adierazteko erabilitako laburdurak:

\begin{tabular}{|l|l|}
\hline \multicolumn{1}{|c|}{ Kategoria } & \multicolumn{1}{c|}{ Laburdurak } \\
\hline Izena & iz. \\
\hline Adjektiboa & adj. \\
\hline Aditza & ad. \\
\hline Adberbioa & adb. \\
\hline Izenordaina & izord. \\
\hline Erakuslea & erak. \\
\hline Zenbatzailea & zenb. \\
\hline Juntagailua & junt. \\
\hline Interjekzioa & interj. \\
\hline
\end{tabular}

— Aditzen sarrerak (ad.)

Aditz guztiekin hiru forma eman dira: partizipioa (emán), aditz-oina (emà) eta aditz-izena (emàtte). Bi arrazoirengatik: batetik, hala egiten da hiztegi gehienetan eta, bestetik, azentuera aldakorra duten aditzen izaera adierazteko modu bat da, askotan aldatzen baita azentuera forma batetik bestera.

Azentuera aldakorra duten aditz sarreretan * ikurra jarri dugu. Aldakortasun hau aditzak azentua azken silaban duenean ageri da eta aldakortasuna honetan datza: azentua azken silaban eta goranzkoa duen aditz-partizipioak, aditz-oina eta aditz-izena beheranzko azentuarekin ditu.

Gaztelaniarako itzulpena. Itzulpen hau sartzeko, euskaraz adierazitako hitza hobekien adierazten duen aldaera aukeratzea izan da irizpidea. Nagusiki, Elhuyar hiztegi elektronikoaz baliatu gara. 
Azkenik, hitz sarreretan batzuetan agertzen diren elementuak azalduko ditugu:

Izartxoaren bidez, azentuera aldakorra duten sarrerak markatu ditugu. Azentua markatzea zail egiten diren hitzak dira, goranzko nahiz beheranzko azentuarekin esaten direlako, testuinguruaren arabera. Esaldian duten prosodiaren arabera (intonazioa) aldatzen dira. Ondoren $-a$ artikulua gehituta edo $i z a n$ aditza jarrita duen azentua adierazi da honelakoetan, neutroena delakoan. Horrela eginda, normalean, goranzko azentua darama, akutua.

Azentuera aldakorra duten hitzak, bi hitz multzotan bana daitezke: silaba bakarreko hitzak ${ }^{1}$ eta azentua azken silaban daramaten aditz eta adberbioak.

Izen eta adjektiboen kasuan orokortasun hau gertatzen da: oinarrizko forman adierazten dugun azentua, singularrean erabiltzen dena da. Adibidez, adár, adárra, adárrari, adárren 'adarrean'. Aldiz, singularrean eta mugagabean goranzko azentua duten hitz askok beheranzkoa dute pluralean (lau silaba baino gutxiagoko hitz guztiek), adib. adàrrak, adàrrari 'adarrei', adàrratan, etab. Honetaz dihardu Hualde, Lujanbio, Torreiraren artikuluak ere (aurrerantzean HL\&T 2008).

- * aditzetan. Aditzen kasuan, batzuetan aldakortasuna dago aditz-partizipio, aditz-oin eta aditz-izenaren artean. Aldakortasun hau adierazteko ere * erabili da.

*artú, àr, artzèn (hartu)

Bóltsa artú dut; àr tzo bóltsa; bóltsa artzèn ái naiz.

*así, às/así, astèn (hasi)

Lánen así naiz; às zittez lánenlasí zittez lánen; astèn al tza áuro lánen.

— * adberbioetan. Adberbioen kasuan, izan aditzarekin esanez gero, azentu akutua dute. Bakarrik esanez gero, azentu grabea dute. Izan aditzarekin azentu neutroagoa dutelakoan, hori adierazi da hiztegian.

*án (han)

Án da itxéa. Non? Àn.

*atzó (atzo)

Atzó zen bazkaria. Noiz? Atzò.

Puntu hauek sakonago aztertu dira 4.2.1. Silababakarren azentua eta 4.2.2. Aditz jokatuen azentua eta 4.2.3. Adberbioen azentua ataletan.

$g z t$ eta $z h r$. Ikur hauek daramatzaten hitzak erabilera zabala ez dutenak dira. Sarrera-hitzaren ondotik, kurtsiban agertzen diren laburdura hauen esanahia honakoa da: gzt: batez ere gazteek erabiltzen duten aldaera, zhr: batez ere helduek erabiltzen duten aldaera.

Adibidez, arbáso sarreran gzt ipini dugu eta árdi (ahardi) sarreran, aldiz, zhr. Bestalde, hitz batzuetarako, bi aldaera emango ditugu, adib.: abéts $z h r$, abérats gzt. Beste batzuetan, hau ager daiteke: abíon, abíoi gzt. Honek, abioi batez ere gazteek erabiltzen dutela adierazten du. Beraz, laburdura hauetako bakoitzak aurretik duen hitzari bakarrik egiten dio erreferentzia.

\footnotetext{
${ }^{1}$ Bidenabar, bi silabatan edo bakarrean ahoskatzen den jakiteko egon daitezkeen zalantzak argitzen ditu *ikurrak.
} 
Laukiak. Azkenik, lauki batean sartu ditugu, hizki berberak izan arren, azentu diferentea duten hitzak.

\subsubsection{Beste azalpen batzuk}

Ortografia. Euskararen ohiko ortografia erabili dugu, baina Goizuetako sistema fonologikoari egokituta. Horri buruz bi ohar egin behar ditugu. Alde batetik, hiztegian ez da $h$-rik erabili eta, bestetik, $j$ hizkia erabili dugu beloko frikari ahoskabea, /x/, adierazteko eta $y$ hizkia hurbilkari sabaikari ahostuna, /j/, idazteko.

Hitzak kategoria lexikal bat baino gehiago dituenean. Sarrera ezberdinak eman dira, hurrenkera honetan: izena, adjektibo, aditza, adberbioa, zenbatzailea, juntagailua, interjekzioa, izenordaina, erakuslea (goiko taularen hurrenkera bera). Kategoria lexikal berean adiera ezberdinak daudenean, sarrera berean eman dira, zenbakiz bereiziak. Adibidez:

kóntu (kontu) iz. 1 conocimiento 2 cuento 3 excusa

kóntu, kòn, kòntzen (kontu) ad. sostener

Hiztegi hau semantikoa ez denez, adiera nagusiak bereizi arren, hiru adiera baino gehiago ez dira eman. Azpisarrerak hitz konposatu eta esamoldeetan erabili dira. Adibidez:

$$
\begin{aligned}
& \text { eó (hego) iz. sur } \\
& \text { — eò-aizé (hego haize) iz. viento del sur }
\end{aligned}
$$

Hitz beraren aldaera fonetiko bat baino gehiago erabiltzen direnean. Sarrera berean eman dira, bata bestearen jarraian; aurrena, nire ustez, Goizuetan gaur egun erabiliena dena, ondoren gutxiago erabiltzen dena. Adibidez: bárna, bárrena.

Aldaera fonetikoak hitzaren hasierari eragiten dionetan (pránko, fránko), aldaera bakoitza dagokion hizkian sarrera emanez adierazi dira. Aldaeraren azalpen eta itzulpenak bietako batean bakarrik eman dira, ordea, honen arabera: nire ustez, Goizuetan gehien erabiltzen den aldaeraren sarreran. Beraz, hemen ere, lehentasuna gure ustez gehien erabiltzen denari eman zaio. Adibidez:

pránko. ikus fránko

fránko, pránko (franko) adb. 1 mucho, -a 2 muchas veces 


\subsection{Hiztegia}

A

abàlla (habaila) iz. velocidad

abár zhr (abar) adj. desprendido (despectivo)

abándonatu, abándona, abándonatzen (abandonatu) ad. abandonar

abániko (abaniko) iz. abanico

abére (azienda handia, abere) iz. ganado

abàrka (abarka) iz. abarca

abérats $g z t$, abéts $z h r$ (aberats) iz. / adj. rico, -a

abíadura gzt (abiadura) iz. velocidad

abìtu, abì, abìtzen (abiatu) ad. partir (de, a)

àbill, abíll $g z t$ (abil) adj. hábil

abílidadea (abilidadea) iz. habilidad

abílki (abilki) adb. hábilmente

abíon, abíoi gzt (abioi) iz. avión

abíxtu, abíx, abíxten (abisatu) ad. avisar

adár (adar) iz. rama

adáxka (adaxka) iz. ramita

adín gzt (adin) iz. edad

adíntsukoa izan (adin bertsukoa izan)

adískidantza $z h r$ (adiskidantza) iz. amistad

adìskide $z h r$, adískide $z h r$, aixkide $z h r$ (adis-

kide) iz. amigo, -a

aèri izan (ageri izan) ad. verse, aparecer

afàlaurré (afalaurre) adb. tiempo antes de cenar

*afáldu, afâl, afâltzen (afaldu) ad. cenar

afàlondó (afalondo) adb. tiempo después de cenar, sobremesa

afári (afari) iz. cena

— afári-berèndu (afari-merienda) iz. merienda-cena

agá $z h r$ (haga) iz. vara

*ái (ahi) iz. papilla (hecha con harina y leche)

*àik (haiek) erak. aquellos, -as

*àik (haiek) izord. aquéllos, -as

aiéka (aieka) iz. lado

aiétu, aié, aiétzen / allétu (ailegatu) ad. llegar aiéntu, aién, aiéntzen (aienatu) ad. desaparecer

aièrrak eón (aiherrak egon) ad. tener ganas

áinbeste (hainbeste) adb. tanto

*áindu, àin, àintzen / áinddu (agindu) ad. mandar

aingèru (aingeru) iz. ángel

aingìra (aingira) iz. anguila

aíntari (agintari) iz. autoridad, jefe

aìnte (aginte) iz. poder

aió (adio) interj. adiós

*aipátu, aipà, aipàtzen (aipatu) ad. mencionar

airàtu, airà, airàtzen (airatu) ad. 1 volar 2 ponerse chulo (harrotu)

áire (aire) iz. 1 parecido 2 aire

*áittu, ài, àitzen (aditu) ad. oír

*àitz (hagitz) adb. muy

*áitz (haitz) iz. roca

aitzàki (aitzaki) iz. escusa

aitzúr (aitzur) iz. azada

àixa (aise) adb. fácilmente

àixtin (arestian) adb. recientemente

aizàtu, aizà, aizàtzen (haizatu) ad. inflar

aizé (haize) iz. viento

aizkòra (aizkora) iz. hacha

aizkólari (aizkolari) iz. cortador de tron$\cos$

áizpa (ahizpa) iz. hermana

àje (aje) iz. resaca
ajétu (ajetu) adj. trastornado, -a
akàńa (akain) iz. garrapata
akàso (akaso) adb. acaso
akátu, aká, akátzen (akabatu) ad. matar
alkàzi, akàzi (akazia) iz. acacia
akér (aker) iz. cabrón
akétz (aketz) iz. verraco
ála (hala) adb. así
alába (alaba) iz. hija
alái (alai) adj. alegre
álajáinkoa (alajainkoa) interj. ipor Dios!


albàiteró $z h r$. (albaitari) iz. veterinario, -a aldápa (aldapa) iz. cuesta

aldáre (aldare) iz. altar

aldátu, aldá, aldátzen (aldatu) ad. cambiar aldé (alde) iz. 1 lado 2 zona

aldéin (alde egin) ad. irse

aldérdi (alderdi) iz. 1 zona 2 partido (político)

aldí (aldi) iz. vez

aldìro (aldi oro) adb. cada vez, siempre

alé (ale) iz. grano
àle (hala ere) junt. a pesar de todo

aléia (alegia) junt. es decir

aléiñ. ikus iñalak

algára (algara) iz. carcajada

alkándora (alkandora) iz. camisa

alkáte (alkate) iz. alcalde

almúada (burko) iz. almohada

alór (alor) iz. campo cultivado

alpér (alfer) adj. vago, -a

alpérkeri (alferkeria) iz. vagancia

alpérrik (alferrik) adb. inútilmente

áltu (altu) adj. alto, -a

altxàtu, altxà, altxàtzen (altxatu) ad. 1 subir

2 recoger, guardar

altza (haltz) iz. aliso

alú (alu) adj. canalla

alúita (alubita) adj. canalla

alúkeria (alukeria) iz. putada

áma (ama) iz. madre

amàiarra $z h r$ (amaginarreba) iz. suegra

\begin{tabular}{l}
\hline amáika (hamaika) zenb. once \\
amàikatako (hamaiketako) iz. almuerzo
\end{tabular}

amàr (hamar) zenb. diez

amà(r)jin bat (amabirjin bat) zenb. muchos, -as

Amá(bi)rjinák, Amà(bi)rjinák (Amabirjinak) iz. Fiestas de la Virgen

amàutxi (amabitxi) iz. madrina

amázulo (amazulo) adj. enmadrado

amíldei (amildegi) iz. precipicio

*amíldu, amil, amiltzen (amildu) ad. precipitarse

amón (amona) iz. abuela

*amóndu, amòn, amòntzen (amondu) ad. convertir(se) en abuela amórrazio (amorrazio) iz. rábia

amòrri (amuarrain) iz. trucha

*án (han) adb. allí

anái (anaia) iz. hermano

andré (andre) iz. 1 señora 2 mujer 3 esposa

andrègai (andregai) iz. novia

ànima. ikus àrima

anímali (animalia) iz. animal

ánka (hanka) iz. pierna
ankàzpi (hankazpi) iz. planta [del pie]

ántsi (antsi) iz. ansia

ántxe (hantxe) adb. allí mismo

antxòa (antxoa) iz. anchoa

antxúme (antxume) iz. cabrito, -a

ántza (antz) iz. parecido

antzára (antzara) iz. ganso

antzóso (antzetsu) adj. hábil, eskulanetan trebe

antzú (antzu) adj. estéril

*antzútu, antzù, antzùtzen (antzutu) ad. volverse estéril

*áń (hagin) iz. muela

àńa (adina) adb. tanto como

añár (ainar) iz. brezo

áo (aho) iz. boca

—áo-aundì, aó-aundì (aho handi) adj. bocazas

— aó-zabàl (aho zabal) adj. bocazas

— aó zabàlka (aho zabalka) adb. bostezando

—aó-zabàlka (aho-zabalka) iz. bostezo aòntu, aòn, aòntzen (agoantatu) ad. aguan$\operatorname{tar}$

apál (apal) iz. estante

apál (apal) adj. humilde

apár (apar) iz. espuma

apàrte (aparte) adb. 1 lejos 2 aparte

*apátx (apatx) adb. modo de sentarse, con

los pies cruzados

apèz (apez) iz. cura, sacerdote

ápo $z h r$. ikus zápo

apópillo (apopilo) iz. huésped, -a

apòstolú (apostolu) iz. apóstol

apóstu (apustu) iz. apuesta

aprópos (apropos) adj. adecuado, -a

aprópos. ikus pròpio 
apróxtu, apróx, apróxten (aprobetxatu) ad. aprovechar

apúntu, apún, apúntzen (apuntatu) ad. apuntar

*ár (har) iz. gusano

*àr (ar) adj. macho

arági (haragi) iz. carne

Aràno (Arano) iz. Arano

aràbera (arabera) adb. según

arákindei gzt (harakindegi) iz. carnicería

arán gzt (haran) iz. valle

arán (aran) iz. ciruela

arántza (arantza) iz. espina

árba (arba) iz. 1 ramiza 2 tutor

arbáso gzt (arbaso) iz. antepasado

arbázta (arbazta) iz. palo largo y fino

arbí (arbi) iz. nabo

àrbol (arbola) iz. árbol

ardí (ardi) iz. oveja

ardó (ardo) iz. vino

arétxe (aratxe) iz. ternero, -a

argí (argi) iz. luz

argí (argi) adj. listo, -a

argí (argi) adb. claro, -a

argíziri (argizari) iz. 1 cera 2 vela

\begin{tabular}{|l|}
\hline arí (hari) iz. hilo \\
ári (ahari) iz. carnero \\
\hline
\end{tabular}

àrima (arima) iz. alma

arín (arin) adj. ligero, - -a*

aríndu, arìn, arìntzen (arindu) ad. aligerar(se)

arítz (haritz) iz. roble

arkáitz (arkaitz) iz. peńa

*arkáldu, arkal, arkàltzen (arkaratu) ad. ponerse en celo (las ovejas)

arkára (arkara) adb. en celo (las ovejas)

arkúme (arkume) iz. cordero

arkùpe (arkupe) iz. soportal

árma (arma) iz. arma

armàrio (armario) iz. armario

armíarma (armiarma) iz. araña

amòrri (amuarrain) iz. trucha

arnás. ikus esnási

arnásestuka (arnasestuka) adb. jadeando

arótz $z h r$ (arotz) iz. 1 herrero, -a 2 trabaja-

dor, -ora en construcción $z h r$

arpéi, aurpéi, árpi $z h r$ (aurpegi) iz. cara arrái (arrain) iz. pez

arráillatu $z h r$ (arraildu) iz. rajarse (la pared)

arrákasta $g z t$ (arrakasta) iz. éxito

arráindei, arrándei (arrandegi) iz. pescadería

arrámazka (harramazka) iz. arańazo

arràno (arrano) iz. águila

arràntza (arrantza) iz. pesca

arràntza in (arrantza egin) ad. pescar

arrántza (arrantza) iz. rebuzno

arrántza in (arrantza egin) ad. rebuznar

arrántzale (arrantzale) iz. pescador

arràntzará yon (arrantzara joan) ad. ir a pescar

arrápatu, arrápa, arrápatzen (harrapatu) ad.

encontrar, pillar

arrástan (arrastaka) adb. arrastrando

arrástaka (arrastaka) adb. arrastrando

arrátoi (arratoi) iz. rata

arráts (arrats) iz. noche

arràtsaldé, arràseldé, arràsaldé (arratsalde) iz. tarde

arràutza (arrautz) iz. huevo

— arráutza-azàla

arrázoi (arrazoi) iz. razón

arréba (arreba) iz. hermana de un hombre

arrí (harri) iz. piedra

*arrì ín, arrí in (harri egin) ad. emborracharse

arrika (harrika) iz. a pedradas

arrímatu (arrimatu) iz. arrimarse

arró (harro) adj. arrogante, orgulloso

arrópa (arropa) iz. ropa

*arrótu, arrò, arròtzen (harrotu) ad. 1 volverse arrogante 2 enorgullecerse 3 ahuecarse

arrùbia (arrabio) iz. salamandra

*arrùnt (arrunt) adb. muy
arrúnt gzt (arrunt) adj. normal

artáburu (artaburu) iz. mazorca de maíz

artálde (artalde) iz. rebaño de ovejas

árte (arte) iz. 1 encina (ez omen da Goi-
zuetan) 2 arte
arté (arte) adb. hasta

artési (artesi) iz. raja

artésittu, artési, artésitzen (artesitu) ad. ra-

jarse

artó (arto) iz. maíz

*artú, àr, artzèn (hartu) ad. tomar 
artzái (artzain) iz. pastor

artzài ibíl(l)i (artzain) adb. pastor

artzàntza (artzaintza) iz. oficio de pastor

asérre (haserre) iz. enfado

asérre (haserre) adj. enfadado

*asértu, asèr, asèrtzen (haserretu) ad. enfadar

*así, às / así, astèn (hasi) ad. empezar

asiera (hasiera) iz. principio

áska (aska) iz. abrevadero

askí (aski) adb. suficiente

askó (asko) zenb. mucho, -s

*asmátu, asmà, asmàtzen (asmatu) ad. adivinar

asmó, ásmo (asmo) iz. intención

aspáldi (aspaldi) adb. hace tiempo

aspérgarri (aspergarri) adj. aburrido, -a

*aspértu, aspèr, aspèrtzen (aspertu) ad. abu$\operatorname{rrir}(\mathrm{se})$

astákeri (astakeria) iz. burrada

astàpitó, astòpitó (astapito) adj. tonto, -a astàr (astar) iz. burro (macho)

asté (aste) iz. semana

astéburu (asteburu) iz. fin de semana

astéko (asteko) adj. de semana

astèko (hasteko) adb. para empezar

astéarte (astearte) iz. martes

astelén, astélen (astelehen) iz. lunes

aste(a)zkén, astéazken (asteazken) iz. miércoles

astéun (astegun) iz. día laborable

astíar (astigar) iz. arce

astínaldi (astinaldi) iz. sacudida

astó (asto) iz. burro

aspáldi (aspaldi) adb. hace tiempo

atáka (ataka) iz. portezuela

atàke (atake) iz. ataque

atári (atari) iz. entrada de la casa (por fuera)

atárramentu (atarramentu) iz. provecho, rendimiento

atàutxi (aitabitxi) iz. padrino

áte (ahate) iz. pato
até (ate) iz. puerta
atère, atè, atètzen (atera) ad. salir
atéri (ateri) adj. tiempo escampado
atéri eon (ateri egon) ad. estar escampado
atèrpe (aterpe) iz. refugio

atértu, atèr, atèrtzen (atertu) ad. escampar

atséiń (atsegin) adj. agradable

atsó (atso) iz. 1 vieja 2 tía buena

átta (aita) iz. padre

attàiarra $z h r$ (aitaginarreba) iz. suegro

attóna (aitona) iz. abuelo

áttu, áttu, áttutzen (ahitu) ad. acabar

atzápar (atzapar) iz. zarpa, manaza

àtze (atze) iz. detrás

*atzéndu, atzèn, atzèntzen $z h r$ (atzendu)

ad. olvidar

àtzetu, àtze, àtzetzen (atzeratu) ad. atrasar

*atzó (atzo) adb. ayer

*áu (hau) erak. este, esta

*áu (hau) izord. éste, ésta, esto

aújeta(k) (gihar-min) iz. agujeta

aukéra (aukera) iz. oportunidad

aukératu, aukéra, aukératzen (aukeratu) ad. elegir

ául, aúl (ahul) adj. débil

*áuldu, àul, aultzén (ahuldu) ad. debilitar(se)

aulkí (aulki) iz. silla

aundí (handi, haundi) adj. grande

áuntz (ahuntz) iz. 1 cabra 2 borrachera

áuro, áudo, abúdo (aguro) adb. rápido

àurre (aurre) iz. delante

aurtén (aurten) iz. este año

àurretú, àurre, àurretzén (aurreratu) ad. adelantar

àuskalo (auskalo) interj. a saber

auspèz, auspèzka $z h r$ (ahuspezka) adb. boca abajo

auspó (hauspo) iz. fuelle

áuts (hauts) iz. polvo

*autsí, àus, austèn / autsìtzen (hautsi) ad. romper

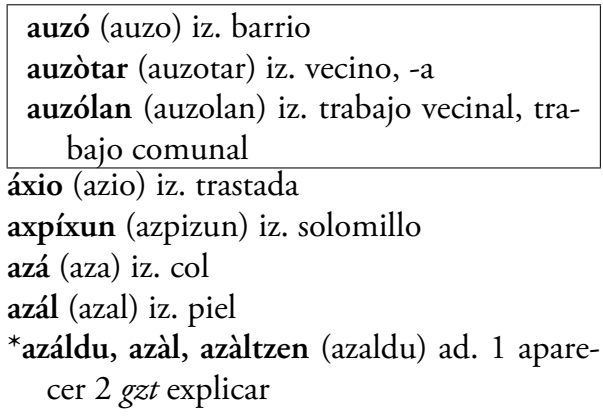


azèri (azeri) iz. zorro

azí (hazi) iz. semilla

*azí, àz, azìtzen (hazi) ad. 1 crecer 2 criar

3 inflar

azìnda (azienda) iz. ganado

ázio, áxio (azio) iz. trastada

azkànarró (azkonar) iz. tejón

azkúre (azkura) iz. picor azmár, auzmár (hausnar) iz. rumia

*azmártu, azmàr, azmàrtzen / auzmártu (hausnartu) ad. rumiar

azpí (azpi) adb. abajo

*áztu, àz, àzten / áztutzen (ahaztu) ad. olvidar(se)

azùkre (azukre) iz. azúcar

B

babá (baba) iz. 1 haba 2 ampolla

babèrna (babarruna) iz. alubia

baé, bài $z h r$ (bahe) iz. criba

*bài (bai) adb. sí

baiétz (baietz) iz. consentimiento

baiétz (baietz) adb. que sí

baiézko (baiezko) iz. afirmación

bai tó! (bai zera!) interj. ¡anda ya!

bàizikan (baizik) junt. sino

bátten (baitan) adb. dentro de

bádaezpádako (badaezpadako) adb. incierto

bakárdade (bakardade) iz. soledad

bakárra (bakarra) adj. único, -a
bakárra (bakarra) adb. solamente, sólo
que
bakárrik(an) (bakarrik) adj. solo, -a
bakàrti (bakarti) adj. solitario, -a

bakótxa, bakóitza (bakoitza) adj. cada uno, -a

bàla (bala) iz. bala

balántza (balantza) iz. tambaleo

baldár (baldar) adj. torpe

*baldártu, baldàr, baldàrtzen (baldartu) ad. volver(se) torpe

balío izan (balio izan) ad. valer

báju (baxu) adj. bajo, -a

balkói (balkoi) iz. balcón

balói (baloi) iz. balón

- balói-arràka $z h r$ (baloi-arraka) iz. fútbol

banáka [batzuk] (banaka) adj. [unos, -as]

pocos, -as

banàka (banaka) adb. de uno en uno

banàna gzt (banana) iz. banana bápo (bapo) adb. muy bien

baránda (baranda) iz. barandilla

baràtza (baratza) iz. huerta

barátzuri (baratxuri) iz. ajo

barbéri (bizartegi) iz. barbería

barbéro (bizargin) iz. barbero

baré (bare) iz. 1 limaco 2 flato

baré (bare) adb. tranquilo, -a

*barétu, barè, barètzen (baretu) ad. calmar(se)

*barkátu, barkà, barkàtzen (barkatu) ad. perdonar

barkázio (barkazio) iz. perdón

bárna, bárrena (barrena) adb. a través de, por

barrén (barru) iz. interior

Barrèna (Barrena) iz. Barrena

barnétegi gzt (barnetegi) iz. internado

bárra-bárra (barra-barra) adb. en abundancia

barrábill (barrabil) iz. 1 testículo 2 cojón

*bárt (bart) adb. anoche

bart arrátsen (bart arratsean) adb. anoche

barú (barau) iz. ayuno (bijili ta barú)

basákatu (basakatu) iz. gato montés

basàti (basati) adj. salvaje

basàuntz (basahuntz) iz. cabra montesa

basèrri (baserri) iz. caserío

basó (baso) iz. bosque

bàso (baso) iz. vaso

basérritar (baserritar) iz. campesino, -a

basómutill (basomutil) iz. hombre que trabaja en el monte 
basúra (zabor) iz. basura

basúrde (basurde) iz. jabalí

*bát (bat) zenb. uno, -a

batáio, patáio $z h r$ (bataio) iz. bautizo

batàiarri (bataiarri) iz. baptisterio

batázbesteko $g z t$, bátezbèsteko $z h r$ (bataz-

besteko) iz. promedio

batzár gzt (batzar) iz. junta

bàtzuk (batzuk) zenb. unos, -as

baxàkarán, basàkarán (basaran) iz. endrina

bazkàlaurré (bazkalaurre) iz. tiempo anterior a la comida (del mediodía)

bazkàldu, bazkàl, bazkàltzen / bàzkaldu $z h r$ (bazkaldu) ad. comer

bazkàlondo (bazkalondo) iz. sobremesa (del mediodía)

bazkàri, bázkari $z h r$ (bazkari) iz. comida

bazpáre, bádaezpádare (badaezpada) adb. por si acaso

baztér (bazter) iz. lado, rincón, borde, orilla

*baztértu, baztèr, baztèrtzen (baztertu) ad. apartar(se)

bé (behe) iz. abajo

beár (behar) iz. necesidad, deber

beàr, bar, biàr (behar) ad. hay que

beàrko!, biàrko! (beharko!) interj. ¡qué remedio!

*beártu, beàr, beàrtzen (behartu) ad. 1 obligar 2 necesitar

beártsu (behartsu) iz. / adj. pobre

beátz. ikus biátz

- beatz potzólo, behatz lodí (behatz potzolo, behatz lodi) iz. dedo gordo

- beátz pùntta (behatz punta) iz. punta del pie

beázuma (behazun) iz. bilis

bède (bederen) junt. al menos

bedéinkatu, bedéinka, bedéinkatzen (bedeinkatu) ad. bendecir

bèdik $z h r$ (bederik) junt. al menos

beí (begi) iz. ojo

*béi (behi) iz. vaca

- beíluze (begíluze) adj. mirón, -a

*bèin, bèiń (behin) adb. una vez

- beiñ o beiń (behin edo behin) adb. alguna que otra vez
- beiń o beste (behin edo beste) adb. alguna que otra vez

béingoz (behingoz) adb. 1 de una vez para siempre 2 por una vez

béintzat (behintzat) junt. al menos. ikus bède eta bénpe(n), bénpeñen

béitei (behitegi) iz. vaquería

*béitu, bèi, bèitzen (begiratu) iz. mirar

béla (berehala) adb. enseguida

belár (belar) iz. hierba

belàrri (belarri) iz. oreja

- belárrimotz (belarrimotz) iz. término despectivo a veces utilizado para referirse a las personas no originarias del País Vasco o que no conocen el euskara

— belárrondoko (belarrondoko) iz. bofetada

— belàrritako (belarritako) iz. pendiente

berríro (berriro) adb. hace poco tiempo

béira (begira) adb. mirando

* béitu, bèi, bèitzen (begiratu) ad. mirar

bekáñ (bekain) iz. ceja

bekéts (bekaitz) adj. avaricioso, -a, glotón, -a

bekéskeri (bekáizkeria) iz. avaricia, glotonería

belàrri (belarri) iz. oreja

belárrondoko (belarrondoko) iz. bofetada

beláso (belar-soro) iz. pradera

beláun (belaun) iz. rodilla

beláuniko (belauniko) adb. de rodillas

beldúr (beldur) iz. miedo

beldùrti (beldurti) iz. miedoso

belé (bele) iz. pájaros del género Corvus

belíarro (birigarro) iz. zorzal (Turdus philomelos)

béltz (beltz) adj. negro, -a.

benèno (beneno) iz. veneno

bénpe(n), bénpeñen $z h r$ (behinik behin) junt. al menos. ikus bede

bénta (benta) iz. venta (Bentá Berri)

béra (hura, bera) izord. 1 el, élla, éllo 2 el, lo mismo, la misma

berá (bera) adj. blando

Berá $z h r$, Bèra gzt (Bera) iz. Vera de Bidasoa

berándu (berandu) adb. tarde 
- beránduxio (beranduxeago) adb. un poco más tarde

- b. (un poco) demasiado tarde

berántsi (berantetsi) adj. impacientado, -a por la tardanza

*berátu, berà, beràtzen / beráztu, berà, beràtzen (beratu) ad. ablandar(se)

*berdátu, berdà, berdàtzen (berdatu) ad. ponerse verde

bérde (berde) adj. verde

berdín (berdin) adj. igual

- berdìn-berdín

berdíndu, berdìn, berdìntzen (berdindu) ad. igualar(se)

berdúra (berdura, barazki) iz. verdura

beré (bere) izord. su, sus

— berè (g)isá (bere gisa, bakarrik) adb. sólo

— berè $(\mathrm{g})$ isá (bere gisa, indarrik egin gabe) adb. sin hacer fuerza, fácilmente

bere ártan (bere hartan) adb. sin cambios, igual

berèkoi gzt (berekoi) adj. egoísta

beréntu, berén, beréntzen (merendatu) ad. merendar

beréndu (merienda) iz. merienda

*beréx (bereiz) adb. aparte

beréxi (berezi) adj. especial, peculiar

*beréxi, berèx, berèxten / beréxtu (be-

rezi) ad. separar

berèz (berez) adb. de por sí

beró (bero) iz. calor

beró (bero) adj. caliente

*berótu, berò, beròtzen (berotu) ad. calentar(se)

berrí (berri) adj. nuevo, -a

berrí (berri) iz. noticia

berriketa (berriketa) iz. charla

berrítsu (berritsu) adj. charlatán, -ana

berrìz (berriz) adb. de nuevo

bértan (bertan) adb. allí, aquí mismo

bèrtso, bèrso (bertso) iz. verso

bertsólari, bersólari (bertsolari) iz. verso-

lari, poeta oral

besàpe (besape) iz. axila

besó (beso) iz. brazo

- besàmotz (besamotz) adj. manco, -a

besòtako (besoetako) iz. ahijado, -a bèste (beste) adj. otro, -a

besté, bèste (beste) izord. otro, -a

bestéla (bestela) adb. de otro modo

béta (beta) iz. tiempo

*beté, betè, betètzen (bete) ad. llenar

beté (bete) adj. lleno, -a

betè-betén (bete-betean) adb. en medio de, totalmente

betéka (betekada) iz. hartazgo

betí (beti) adb. siempre

betíko (betiko) adj. de siempre

betíko (betiko) adb. para siempre

betítik (betitik) adb. desde siempre

betízu (betizu) iz. vaca salvaje

bétti (beheiti) adb. abajo

- béttiko (beheitiko) iz. diarrea

- béttio (beheitiago) adb. más abajo

- béttixio (beheitixeago) adb. un poco más abajo

- bèttixko (beheitixko) adb. (un poco) demasiado abajo

- bèttigi (beheitiegi) adb. demasiabo abajo

bezèla (bezala) adb. como

bezìn (bezain) tan... como

bezpèra, pezpèra $z h r$ (bezpera) iz. víspera

*bí (bi) zenb. dos

- bítik báten, bíti páten (bien arteko aukeran)

biàje (bidaia) iz. viaje

biàli, biàl, biàltzen (bidali) ad. enviar

*biár (bihar) adb. mañana

- biárko (biharko) adb. para mañana

biámen (biharamun) iz. día siguiente

biátz, beátz (behatz) iz. dedo

bibíroi (biberoi) iz. biberón

bidé (bide) iz. camino

bidénabar (bidenabar) adb. de paso

bidéxka (bidexka) iz. sendero

bidéxior (bidezidor) iz. sendero

bidói (bidoi) iz. bidón

bikóte gzt (bikote) iz. pareja

*billátu, billà, billàtzen (bilatu) ad. buscar

bildóts (bildots) iz. cordero

*bildú, bìl, biltzèn (bildu) ad. 1 recoger

2 agrupar 
billéra gzt (bilera) iz. reunión

*bińo, miño (baina) junt. pero

bióka (behoka) iz. potra

biònbo (bionbo) iz. biombo

biór (behor) iz. yegua

biótz (bihotz) iz. corazón

- biótzaundi (bihotz-handi) adj. generoso, -a

biótzeko (bihotzeko) iz. infarto

bióztar (bihotzerre) iz. acidez de estómago

biríka (birika) iz. pulmón

bísta (bista) iz. 1 paisaje 2 vista

bisúts (bisuts) iz.

*bí (bi) zenb. dos

bítan (bitan) adb. 1 dos veces 2 en dos

bittàrte (bitarte) adb. mientras

biùdo iz. viudo

biúrri (bihurri) adj. 1 travieso, -a 2 torcido, -a - biúrrikeri (bihurrikeria) iz. travesura

biúrrittu, biúrri, biúrritzen (bihurritu) ad. retorcer(se)

*biúrtu, biùr, biúrtzen (bihurtu) ad. volver(se)

bixí, bixì-bixí (bizi) adj. salado, -a, caro, -a

bixí, bixì-bixí (bizi) adb. rápido, caro

bixíta (bisita) iz. visita

bìxki (bizki) iz. gemelo, -a

bizkár (bizkar) iz. 1 espalda 2 cima

- -en bizkàr (bizkar) adb. a cargo de

bizkárrezur (bizkarrezur) iz. columna vertebral

bizkòr, pizkòr, bixkòr, pixkòr (bizkor) adj.

1 fuerte 2 vivaz

bizí (bizi) iz. vida

bizí, bixí (bizi) adj. vivaz

bizì-bizí (bizi-bizi) adb. rápido

*bizí(ttu), bizì, bizitzen (bizi) ad. vivir

bizìtza (bizitza) iz. vivienda

blùsa, brùsa (blusa) iz. blusa

bodèga (bodega) iz. bodega

boláda (bolada) iz. temporada

boládaka (boladaka) adb. a temporadas

bólsa (poltsa) iz. bolsa

bònba (bonba) iz. bomba

bònbo (bonbo) iz. bombo

bórda (borda) iz. borda boróbill (biribil) iz. círculo, redondo

borónte (borondate) iz. voluntad

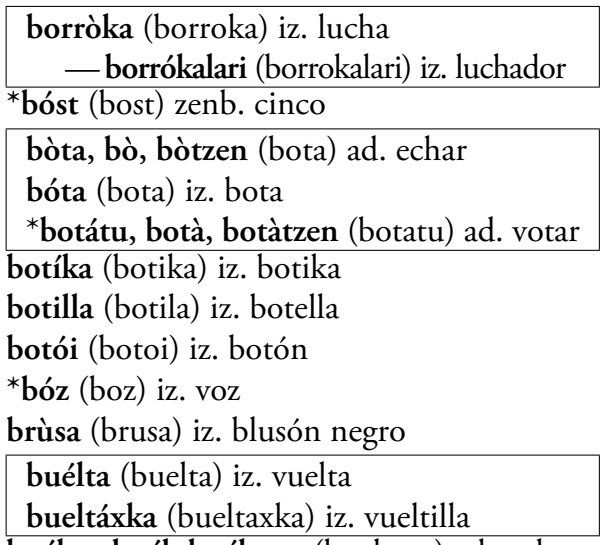

buéltu, buél, buéltzen (bueltatu) ad. volver

*bukátu, bukà, bukàtzen (bukatu) ad. acabar

bulégo gzt (bulego) iz. despacho

búlken, búlkan (bultzaka) adb. empujando

bùlkatu, bùlka, bùlkatzen (bulkatu) ad. empujar

bùlla (zarata) iz. bulla

bullóso (zaratatsu) adj. bullicioso, -a

burbùja (burbuja) iz. burbuja

burlóso (isekari) adj. burlón, -a

burní (burdin) iz. hierro

burníola (burdinola) iz. fábrica de hierro

burrúntzili (burruntzali) iz. cazo

burrùntzi (burruntzi) iz. asador

burú (buru) iz. cabeza

— burùndi (buru-handi) adj. cabezón, $-a$

— burútik yòna (burutik joana) adj. loco, -a

- burútik béttikoa (burutik beherako) iz. constipado

burúarin (buruarin) adj. de poco juicio

burùkoa (burukoa) iz. almohada

burùmakur (burumakur) adj. cabizbajo, -a

*burúz (buruz) adb. de memoria, de cabeza

- burùz bettí (buruz beheiti) adb. cabeza abajo

bustí (busti) adj. mojado, -a

*bustí, bustì, bustìtzen (busti) ad. mojar(se)

buztán (buztan) iz. 1 cola 2 pene

buztín (buztin) iz. arcilla 
damú, dámu (damu) iz. arrepentimiento

*damútu, damù, damùtzen (damutu) ad. arrepentirse

dántza, yántza $z h r$ (dantza) iz. baile — dantzá-saio (dantza-saio) iz. baile dantzáldi (dantzaldi) iz. baile dantzári (dantzari) iz. balarín, -ina

*dantzátu, dantzà, dantzàtzen (dantzatu) ad. bailar

daònekó, dàunekó $z h r$ (dagoeneko) adb. ya daldári, dardári (dardar) iz. tembleque

- daldári báten (dardar batean) adb. temblando

— dardárika (dardarika) adb. temblando

debàlde (debalde) adb. de balde

demónio, demóno (deabru) iz. demonio

dènbo (denbora) iz. tiempo

denbó-pasá (denbora pasa) iz. pasatiempo

denbó-pasá (denbora pasa) adb. pasando el tiempo

dénda (denda) iz. tienda

dendári (dendari) iz. tendero, -a

dèrmio (eremu) iz. terreno

derrépente (derrepente) adb. de repente

desáertu, desáer, desáertzen gzt (desagertu) ad. desaparecer

desbérdin $g z t$ (desberdin) adj. diferente deséin, deséin, deséitten (desegin) ad. deshacer deskùido (deskuidu) iz. descuido desténore $z h r$ (berandu, goiz aldera) iz. deshora

*dèus (deus) adb. algo

dèuséz (deus ez) adb. nada

dexènte (dezente) adb. bastante

dezísio (erabaki) iz. decisión

diféntzia (diferentzia) iz. diferencia

difénte (diferente) iz. diferente

díru (diru) iz. dinero
— dirú-gose (diru-gose) iz. avaricia

dìsko (disko) iz. disco

diskúsio (diskusio) iz. discusión

doblátu, doblà, doblàtzen (doblatu) iz. doblar

dólu gzt (dolu) iz. luto

dolúmiñ (dolumin) iz. pésame

dominixtíku, dóminixtiku (doministiku) iz. estornudo

domíno (domino) iz. dominó

Dómu Sàntu eúna, Domísiñùru $z h r$ (Domu Santu eguna) iz. día de todos los santos

dóńu (doinu) iz. melodía

dozèna (dozena) iz. docena

dró(g)a (droga) iz. droga

dúda (duda) iz. duda

— dúdikan gábe (dudarik gabe) adb. sin lugar a dudas

dúdako (dudako) adj. dudoso, -a

$\mathrm{E}$

eál (hegal) iz. ala eárri (egarri) iz. sed eárrittu, eárri, eárritzen (egarritu) ad. sed eázti (hegazti) iz. ave ebáki, ebáki, ebákitzen / ebàtten zhr (ebaki) ad. cortar ebílli $z h r$, ebíli $z h r$. ikus ibilli, ibili edàri (edari) iz. bebida edé (hede) iz. correa (ed)o (edo) junt. o edózin (edozein) izord. cualquier, -a egílle gzt (egile) iz. autor, -a 
eí (hegi) iz. borde, cumbre

èia (egi) iz. verdad

èitazko (egiazko)

éiz(a) (ehiza) iz. caza

*eizátu, eizà, eizàtzen / eizàtu (ehizatu) ad. cazar

éizera jon (ehizara joan) ad. ir de caza

eiztári (ehiztari) iz. cazador, -a

ekáitz gzt (ekaitz) iz. tormenta

*(e)kárri, (e)kàr, (e)kàrtzen (ekarri) ad. traer

(e)kàrrizí, (e)kàrrizí, (e)kàrrizítzen (ekarrarazi) ad. hacer traer

ekúsi $z h r$. ikus (i)kúsi

elàstiko (elastiko) iz. / adj. elástico, -a

elbárri, elbár (elbarri) iz. minusválido, -a

elbárrittu, elbárri, elbárritzen (elbarritu) ad. quedar impedido, -a

eldú (heldu) iz. / adj. persona mayor

eldù (heldu) ad. venir

eléfante (elefante) iz. elefante

elémentu (elementu) iz. personaje

elémentuk (elementuak) iz. elementos (lluvia... fuerte)

elíz (eliza) iz. iglesia

*elkàr (elkar) izord. mutuamente

elkárte (elkarte) iz. asociación

*elkártu, elkàr, elkàrtzen (elkartu) ad. reunirse

eltxítxu (eltze-itsu) iz. hucha

eltxó (eltxo) iz. mosquito

eltzàri $z h r$ (eltzekari) iz. potaje

eltzé (eltze) iz. puchero

elúr (elur) iz. nieve

elúrbusti (elurbusti) iz. agua-nieve

elùrte (elurte) iz. nevada

emáitz (emaitza) iz. resultado

emákume (emakume) iz. mujer

*(e)mán, (e)mà, (e)màt(t)en (eman) ad. dar emè (eme) iz. / adj. hembra

*emén (hemen) adb. aquí

emen bértan (hemen bertan) adb. aquí mismo

enbáraza(tu) (enbarazatu) adj. enbarazada

enbór (enbor) iz. tronco

enkárgu (enkargu) iz. encargo

énpo in (enpo egin) ad. saciar(se) entérratu, entérra, entérratzen (lurperatu) ad. enterrar

entíerro (entierro) iz. entierro

entsálada (entsalada) iz. ensalada

eó (hego) iz. sur
- eò-aizé (hego haize) iz. viento del
sur

eóki (egoki) adb. adecuadamente

eókittu, eóki, eókitzen (egokitu) ad. adecuar(se)

eòn(du), eòn, eòt(t)en (egon) ad. estar

eònazí, eònazí, eònaztén (egonarazi) ad. hacer estar

*eótu, eò, eòtzeiz. ikus ió(tu)

*eósi, è̀s, eòsten (egosi) ad. cocer

epél (epel) adj. templado, -a

*epéldu, epèl, epèltzen (epeldu) ad. templar

epúrdi, ipúrdi (ipurdi) iz. culo

- epúrdiaundi, ipúrdiaundi (ipurtandi) adj. culón, -a

epúrdiko, ipúrdiko (ipurdiko) iz. culada

epúrmasall $z h r$, ipúrmasai (ipur-masail)

iz. nalga

epùrtargí (ipurtargi) iz. luciérnaga

epúrtzolo (ipurtzulo) iz. ano

ér, edér (eder) adj. 1 bello, -a 2 bueno, -a 3 grande

èrabat (erabat) adb. del todo

erákutsi, erákus, erákusten (erakutsi) ad. enseñar

eràman, eràma, eràmat(t)en (eraman) ad. llevar

eràmanázi, eràmanázi, eràmanazten (eramanarazten) ad. hacer llevar

eráuntsi (erauntsi) iz. torrente de lluvia

*erán, erà, eràten (edan) ad. beber

erànazí, erànazí, erànaztén (edanarazi) ad. hacer beber

*erántzi, erántzi, erántzitzen / erántzi, eràz, eràzten (erantzi) ad. desvestir(se)

eráso (eraso) iz. torrente de lluvia

eràztun (eraztun) iz. anillo

erbí (erbi) iz. liebre

erbìnuré (erbinude) iz. comadreja

erdàldun (erdaldun) iz. castellanoparlante

erdé (lerde) iz. baba 
erdèra, erdàra (erdara) iz. castellano

erdézu (lerdetsu) adj. baboso, -a

erdí (erdi) iz. mitad

—órdu erdì (ordu erdi) iz. media hora

erdibaná (erdibana) adb. a medias

*erdíkatu, erdíka, erdíkatzen / erdikatú, erdika, erdikatzen (erdikatu) ad. partir por la mitad

*erdíttu, erdì, erdìtzen gzt (erditu) ad. dar a luz

erdìzka (erdizka) adb. a medias

erdòi (herdoil) iz. rońa

erdòittu, erdòi, erdòitzen (herdoildu) ad. oxidarse

*eréiń, erèiń, erèitten (erein) ad. sembrar

eréki, eréki, erékitzen (ireki) ad. abrir

erén gzt (heren) iz. tercio

erènu (herenegun) adb. anteayer

ergél (ergel) adj. estúpido, -a

érki (ederki) adb. bien

—érki aski (ederki aski) adb. muy bien

erlé (erle) iz. abeja

erlámando, erlémando (erlamando) iz. zángano

ermítta (ermita) iz. ermita

*ernáldu, ernàl, ernàltzen (ernaldu) ad. fecundar

ernári (ernari) adb. estar preñada

ernàtu, ernà, ernàtzen (ernatu, esnatu) ad. espabilarse

erné (erne) adj. despierto, -a, ingenioso, -a eró (ero) adj. loco, -a

eròri, eròri, eròitzen (erori) ad. caerse

eròrtza (lur-jausi) iz. desprendimiento de tierras

eróstun (erostun) iz. comprador, -a

*erótu, erò, eròtzen (erotu) ad. volver(se) loco, -a

eróxka (eroxka) adj. loquillo, -a

errábi (errabia) iz. rabia

errámu (erramu) iz. laurel

erràpe (errape) iz. mama

érra, edérra (ederra) adj. grande / bueno, -a

erràuts, áuts (errauts) iz. ceniza

erráx, erréx (erraz) adj. / adb. fácil *erré, errè, errètzen (erre) ad. quemar(se)

erré (erre) adj. quemado, -a

erréaldi (errealdi) iz. momento de quemazón

errége (errege) iz. rey

erréińa (erregina) iz. reina

erréiń $z h r$, erréńa $z h r$ (errain) nuera

errèka (erreka) iz. río

errépetu, errépe, errépetzen (erreparatu) ad.

fijarse

erréu (erregu) iz. ruego

erréstan (herrestan) adb. segidan

errèsto (arrasto) iz. señal, marca

errétiratu, errétira, errétiratzen (erretiratu)

ad. retirar(se)

errétolika (erretolika) iz. retahíla

errétxiń (erretxina) iz. resina

errétxiń (erretxin) adj. irritable

errétxindu, errétxin, errétxintzen (erre-

txindu) ad. irritar(se)

erréx. ikus erráx

*erréxtu, errèx, errèxten / erráxtu (erraztu) ad. facilitar

errézelo $z h r$ (errezelo) iz. recelo

errèzo (errezo) iz. rezo

*erréztu, errèz, errèzten (errezatu) ad. rezar

errí (herri) iz. pueblo

erritar (herritar) iz. del pueblo

erríxta (errieta) iz. bronca

errómes gzt (erromes) iz. peregrino, -a

erróskilla (erroskila) iz. rosquilla

erróta (errota) iz. molino

Erròta iz. pertsona izengoitia

errótari (errotari) iz. molinero, -a

errúa $z h r$ (erregu) iz. robo (medida de grano equivalente a media fanega)

*(e)sán, (e)sà, (e)sàten (esan) ad. decir

(e)sànazí, (e)sànazí, (e)sànazítzen / (e)sànaztén (esanarazi) ad. hacer decir

esànerá (esaera) iz. 1 dicho 2 modo de hablar

esí (hesi) iz. vallado

eskàerá (eskaera) iz. petición

eskáillera (eskailera) iz. escalera

eskále (eskale) iz. mendigo, -a 
eskápo (eskapada) iz. escapada, librada

eskármentu (eskarmentu) iz. 1 escarmiento

2 experiencia

eskárpiń (espartin) iz. alpargata

eskás (eskas) adj./adb. flojo, -a, escaso

eskási (eskasia) iz. escasez

* eskástu, eskàs, eskàsten (eskastu) ad. acabarse, desmejorar

* eskátu, eskà, eskàtzen (eskatu) ad. 1 pedir 2 soltar

eské (eske) iz. limosna

*eskéńi, eskèin, eskèintzen (eskaini) ad. ofrecer

eskér (esker) iz. agradecimiento

— eskérrikaskó (eskerrik asko) muchas gracias

eskínoso, eskínuso (eskinoso) iz. arrendajo

eskòba (eskoba) iz. escoba

eskòla (eskola) iz. escuela

eskríbittu, eskríbi, eskríbitzen $z h r$ (eskri-

bitu) ad. escribir

eskú (esku) iz. mano

— eskúzikin (eskuzikin) adj. el, la que tiene manos sucias

— eskùmotx, eskùmotz (eskumotz) adj. manco, -a

eskuíń, eskúñ (eskuin) iz. derecha

eskúminak (eskuminak) iz. recuerdos

esnási, arnás (arnas) iz. respiración

esnàtu, esnà, esnàtzen (esnatu) ad. desper-

tarse

esnázu $z h r$ (esnetsu) iz. que da mucha leche esné (esne) iz. leche

esnéketari (esneketari) iz. lechero, -a

éspa (espa) iz. afán

espántu (espantu) iz. aspaviento

espántuka (espantuka) iz. fanfarroneando

espéntza (esperantza) iz. esperanza

espèrma gzt (esperma) iz. esperma

espétu, espé, espétzen (esperatu) ad. espe-

rar

espézial (espezial) adb. muy bien

espillu (ispilu) iz. espejo

espóstu $z h r$ (esposatu) ad. casarse

estàlpe (estalpe) iz. cobertizo

estárta (estarta) iz. hueco entre dos casas esté (heste) iz. intestino

estréinttu, estréin, estréintzen (estreinatu)

ad. estrenar(se)

estrèlla $z h r$ (ortzadar) iz. arco iris

estú (estu) adj. estrecho, -a

*estútu, estù, estùtzen (estutu) ad. apretar

etórri (etorri) iz. elocuencia

*(e)tórri, tòr, tòrtzen (etorri) ad. venir

*etsí, etsì, etsìtzen (etsi) ad. rendirse

etsì-etsín (etsi-etsian) adb. sin otro remedio

etsík artú (etsiak hartu) ad. rendirse

etzànta (etzanda) adj. tumbado, -a

*etzí (etzi) adb. pasado mañana
etzímu (etzidamu) adb. el día siguiente a
pasado mańana
éuki(ttu), éuki, éukitzen (eduki) ad. tener

eulí (euli) iz. mosca

\begin{tabular}{l}
\hline eún (egun) iz. día \\
*eún (ehun) zenb. cien \\
eúr (egur) iz. 1 madera 2 leña
\end{tabular}

eúr (egur) iz. 1 madera 2 leńa

éurdi (eguerdi) iz. mediodía

eurí (euri) iz. lluvia

Eùrrik (Eguberriak) iz. Navidades

euskàldun, eskuàldun $z h r$ (euskaldun) iz. I

adj. vasco, -a

euskèra, euskàra, eskuàra $z h r$ (euskara) iz. euskera

*éutsi, èus, èusten / éutsi, éutsi, éutsitzen (eutsi) ad. agarrar, sostener

eùterá (egutera) iz. solana

eùzki, iùzki $z h r$ (eguzki) iz. sol

exéri, exéri, exéritzen (eseri) ad. sentar(se)

exkáx (eskas) adj. insuficiente

*exkáxtu, exkàx, exkàxten (eskastu) ad. desmejorar

*èz (ez) adb. no

ezári-ezárin (ezari-ezarian) adb. pixkanaka

ezáun, ezáon (ezagun) adj. conocido, -a

ezáutu, ezáu, ezáutzen / ezáotu, izáutu, izáotu (ezagutu) ad. conocer

ezáutza gzt (ezagutza) iz. conocimiento

ezézaun (ezezagun) adj. desconocido, -a

*ezí(ttu), ezì, ezìtzen (hezi) ad. educar

ezín, ezína (ezin) iz. (lo) imposible

ezíndu gzt (ezindu) iz. minusválido, -a

ezkilla (ezkila) iz. campana 
*ezkóndu, ezkòn, ezkòntzen (ezkondu)
ad. casarse

ezkòntza (ezkontza) iz. matrimonio

ezkúr (ezkur) iz. bellota

ezpál (ezpal) iz. astilla

ezpáta (ezpata) iz. espada eztàrri (eztarri) iz. garganta

eztén (ezten) iz. aguijón

eztí (ezti) iz. miel

eztúl (eztul) iz. tos

ezúr (hezur) iz. hueso

F

fabóre (fabore) iz. favor

fâbriká (fabrika) iz. fábrica

faja (faja) iz. faja

falta (falta) iz. falta

fâlta izan (falta izan) ad. carecer de

fáltso, páltso $z h r$ (faltso) adj. falso, -a

faltsókeri, paltsókeri $z h r$ (faltsukeria) iz. falsedad

famátu (famatu) adj. famoso, -a

famili (familia) iz. familia

famóso $z h r$ (famoso) adj. famoso, -a

fanfárroi (fanfarroi) adj. fanfarrón, -a

féde (fede) iz. fe

fedédun (fededun) iz. / adj. creyente

fenòmenó (fenomeno) iz. fenómeno

*fiátu, fià, fiàtzen (fidatu) ad. fiarse

fiésta, fièstak (festa) iz. fiesta

— festàurre (festaurre) adb. tiempo antes de fiestas

— festóndore (festondore) adb. 1 tiempo después de fiestas 2 resaca *fín (fin) adj. fino, -a

*findú, fin, fintzen (findu) ad. refinar(se)

fisiko (fisiko) iz. / adj. físico

*flakátu, flakà, flakàtzen (flakatu) ad. adelgazar

fláko (flako) adj. flaco, -a

foka (foka) iz. foca

fòko (foko) iz. foco

fòsil (fosil) iz. fosil

fráile (fraide) iz. fraile

fránko, pránko (franko) adb. 1 mucho, -a 2 muchas veces

fránko (franko) adb. muy

frantzés (frantses) iz. / adj. francés, -a

frésko (fresko) adj. fresco, -a

freskúra (freskura) iz. frescura

frontói (frontoi) iz. frontón

frúta (fruta) iz. fruta

frutéro (frutari) iz. frutero

frutèro (fruta-ontzi) iz. frutero

fundámentu (fundamentu) iz. fundamento

G

gábe (gabe) adb. sin

gabènteníkan (gabe) adb. sin

gabíroi (gabirai) iz. gavilán

gainbèra (gainbehera) iz. 1 cuesta descendente 2 decadencia gainbèra (gain behera) adb. de arriba a abajo gàinka (gainka) adb. uno, -a encima de otro, -a

gaitséts (gaitzets) iz. cria repudiada por su madre 
* gaitsétsi, gaitsèts, gaitsèsten (gaitzetsi) ad. repudiar

* gáitz (gaitz) iz. enfermedad

gaixó (gaixo) adj. desgraciado

gaixó eon $z h r$ (gaixo egon) ad. estar en-

fermo

ga(i)xtákeri (gaiztakeria) iz. maldad

* ga(i)xtátu, ga(i)xtà, ga(i)xtàtzen (gaiztotu) ad. infectar(se)

ga(i)xtó, gextó (gaizto) adj. malo, -a

* ga(i)xtótu, ga(i)xtò, ga(i)xtòtzen (gaiztotu)

ad. volver(se) malo, -a

gáizki (gaizki) adb. mal

gáizki eon (gaizki egon) ad. estar enfermo

gáizkittu, gáizki, gáizkitzen (gaizkitu) ad. enfermar

galánta (galant) adj. grande

galbài $z h r$. ikus baé

gàldera (galdera) iz. pregunta

* galdú, gàl, galtzèn (galdu) ad. perder

gálezi, gálezi, gálezten / gálazi, gálazi, gá-

lazten (galarazi) ad. no permitir

* galléndu, gallèn, gallèntzen $z h r$ (gailendu)

ad. dominar

gàltu, gàl, gàltzen (galdetu) ad. preguntar

gáltza (galtza) iz. pantalón

— galtzàundi (galtzaundi) iz. calzonazos

galtzálle (galtzaile) iz. / adj. perdedor, -a

galtzérdi (galtzerdi) iz. calcetín

galtzórin (galzorian) adb. en vías de desa-

parición

ganádu (ganadu) iz. ganado

ganbàra (ganbara) iz. desván

ganddéi $z h r$ (gaindegi) iz. piso de debajo del

tejado, encima del desván

gandú (gandu) iz. bruma

* gántz $z h r$ (gantz) iz. grasa

* gáń (gain) iz. 1 cima 2 nata

gàñekon (gainerakoan) adb. sino

gàñera (gainera) junt. además

gànezka (gainezka) adb. desbordando(se)

garágar (garagar) iz. cebada

garái (garai) iz. época

garàikaldé (goialde) iz. parte superior

garàje (garaje) iz. garaje

garbí (garbi) adj. limpio, -a garbítasun (garbitasun) iz. limpieza

* garbíttu, garbì, garbìtzen (garbitu) ad.

1 limpiar 2 matar

garésti (garesti) iz. caro

garéstittu, garésti, garéstitzen (garestitu)

ad. encarecer(se)

gargéro $z h r$ (gaurgero) adb. para ahora

garí (gari) iz. trigo

garízuma (garizuma) iz. cuaresma

gástu (gastu) iz. gasto

gatázka gzt (gatazka) iz. problema. ikus katàzka

* gátz (gatz) iz. sal

gatzári (gatzagi) iz. cuajo

* gáu, gába (gau) iz. noche

gáur (gaur) adb. hoy

gáupasa (gaupasa) iz. pasar toda la noche divirtiéndose, de juerga o fuera de casa

gáuz(a) (gauza) iz. cosa

gazí (gazi) adj. 1 salado, -a 2 agrio, -a

gaztá (gazta) iz. queso

gaztáńa (gaztaina) iz. castaña

gaztáńeri (gaztainadi) iz. castañar

gaztándei (gaztandegi) iz. quesería

gaztánbara, gaztánbera (gaztanbera) iz. cuajada

gazté (gazte) iz. joven

gaztélu gzt (gaztelu) iz. castillo

gaztéri (gazteria) iz. jóvenes

* gaztétu, gaztè, gaztètzen (gaztetu) ad. rejuvenecer(se)

gazúra (gazur) iz. suero (de la leche)

gèigi (gehiegi) adb. demasiado, -a gèienbat (gehienbat) adb. sobre todo géio, gèio $z h r$ (gehiago) adb. más

géittu, gèi, gèitzen (gehitu) ad. sumar

géla gzt (gela) iz. habitación, cuarto. ikus orma

geldí (geldi) adb. quieto, -a

geldíttu, geldì, geldìtzen (gelditu) ad. pa$\operatorname{rar}(\mathrm{se})$

gerézi (gerezi) iz. cereza

geríza, keríza (geriza) iz. cobijo, sombra

géro (gero) adb. después

gérra (gerra) iz. guerra

gerrí (gerri) iz. cintura 
gerríko (gerriko) iz. cinturón

gertátu, gertà, gertàtzen gzt (gertatu) ad. suceder

gértu (gertu) adb. cerca

gezúr (gezur) iz. mentira

* gezúrti, gezùrti (gezurti) iz. / adj. mentiroso, -a

gibél (gibel) iz. hígado

gibéla éuki (gibela eduki) ad. ser vago, sin preocupaciones

gibèlurdín (gibelurdin) iz. cierta seta de cura (russula virescens)

gidári gzt (gidari) iz. chófer

giltxúrdin (giltzurrun) iz. riñón

gíltza (giltz) iz. llave

gíro (giro) iz. tiempo atmosférico, ambiente

(-en) gísa (bezala) adb. como

gitàrra (gitarra) iz. gitarra

gizàjo, gixàjo (gizajo) adj. desgraciado

gizáseme (gizaseme) iz. hombre

gizén (gizen) adj. gordo, -a

* gizéndu, gizèn, gizèntzen (gizendu) ad. engordar

gizón (gizon) iz. hombre

* gizóndu, gizòn, gizòntzen (gizondu) ad. hacer(se) hombre

* gó (gogoa) iz. ganas

— góa izan, góa éuki (gogoa izan, eduki) ad. tener ganas

- go báten eon (gogo batean egon) ad. tener ganas

gói (goi) iz. 1 parte superior 2 arriba

goibél (goibel) adj. triste

* goibéldu, goibèl, goibèltzen (goibeldu) ad. entristecer

* góiz (goiz) iz. mañana

* góiz (goiz) adb. temprano

- goizálde (goizalde) adb. amanecer

Goizùta (Goizueta) iz. Goizueta

goldé (golde) iz. arado

gòma (goma) iz. goma

gón artú (gogoan hartu) ad. tener en cuenta gòna (gona) iz. falda

* gór (gogor) adj. duro, -a

goràbera (gorabehera) iz. 1 altibajo 2 peripecia gordé (gorde) adj. escondido, -a

* gordé, gordè, gordètzen (gorde) ad. escon$\operatorname{der}(\mathrm{se})$

gorósti (gorosti) iz. acebo

gorótz (gorotz) iz. fiemo

gorpútz (gorputz) iz. cuerpo

gorrí (gorri) adj. rojo, -a

gorríngo (gorringo) iz. yema

* górtu, gòr, gòrtzen (gogortu) ad. endurecerse

gosàldu, gosàl, gosàltzen (gosaldu) ad. desayunar

gosàri (gosari) iz. desayuno

gosàlaurré (gosalaurre) adb. tiempo antes de desayunar

gosé (gose) iz. hambre

gosépasatu (gosepasatu) adj. hambriento, -a

* gosétu, gosè, gosètzen (gosetu) ad. tener hambre

gospél. ikus ospél

gòspel (gospel) iz. góspel

gótti (goiti) adb. arriba

- gótti-bètti (goiti-beheiti) adb. altibajos

- góttixio (goitixeago) adb. un poco más arriba

— gòttixkó (goiti xamar) adb. demasiado arriba

góttikok (goitikoak) iz. vómito

— góttikok bóta (goitikoak bota) ad. vomitar

— góttikoka (goitika) adb. vomitando gótu, gó, gótzen (gogoratu) ad. ocurrirse goxó (goxo) adj. sabroso, -a

* goxóki, goxòki, gozòki $z h r$, goxó $z h r$ (gozoki) iz. golosina

goxóki (goxoki) adb. dulcemente

gozó (gozo) adj. dulce

gozózale (gozozale) adj. goloso, -a

grína (grina) iz. ansia

guárda (guarda) iz. guarda

guardásol $z h r$ (aterki) iz. paraguas

guráso, guràsok (guraso) iz. padre o madre

gurdí (gurdi) iz. carro

gurdíbide (gurdibide) iz. camino de carre-

tas 
gurí (guri) adj. 1 blando 2 suave gurútze (gurutze) iz. cruz gurútziltzatu, gurútziltza, gurútziltzatzen (gurutziltzatu) ad. crucificar gùsto (gustu) iz. gusto gùstora (gustura) adb. a gusto

gútxi (gutxi) adb. poco, -a

— gútxi goràberá (gutxi gorabehera) adb. más o menos

guzí (guzi) zenb. todo, -a iáio (iaio) adj. hábil

iár (ihar) adj. 1 seco, -a 2 delgado, -a

*iártu, iàr, iàrtzen (ihartu) ad. 1 secarse 2 adelgazar

*ibíli, ibìl, ibiltzen / ibílli, ebílli, ebíli (ibili) ad. andar, usar, funcionar

idí (idi) iz. buey

idór $z h r$ (idor) adj. seco, -a

idòrte (idorte) iz. sequía

idúittu, idúi, idúitzen (iruditu) ad. parecer

iél (igel) iz. rana

iél (iel) adb. en celo [la yegua y la burra]

iéltsero (igeltsero) iz. albañil

iéltso (igeltsu) iz. yeso

iéri in, iérin ibílli (igeri egin) ad. nadar

iérri, iérri, iérritzen $/{ }^{*}$ iérri, ièr, ièrtzen

(igarri) ad. darse cuenta

iùzki. ikus eìzki

ijìto, kìto $z h r$ (ijito) iz. gitano, -a

ika (hika) adb. tuteando, hablar o escribir utilizando las formas verbales correspondientes al pronombre personal $h i$

ikàri (ikara) iz. susto

*ikértu, ikèr, ikèrtzen gzt (ikertu) ad. investigar

ikiárri (ikaragarri) adb. 1 muy grande 2 estupendo

*(i)kási, (i)kàs, (i)kàsten (ikasi) ad. aprender, estudiar

ikásle (ikasle) iz. estudiante

ikátz (ikatz) iz. carbón

ikázkin (ikazkin) iz. carbonero, -a

*(i)kúsi, (i)kùs, (i)kùsten / *ekúsi zhr (ikusi) ver íl (hil) iz. muerto, -a

*íl, ill, iltzen (hil) ad. morir(se)

ílla (hil) iz. mes

ilbéltz (hilbeltz) iz. enero

ilbèra (ilbehera) iz. luna menguante

ilbérri (ilberri) iz. luna nueva

ilgòra (ilgora) iz. luna creciente

illár (ilar) iz. guisante

illàrgi (ilargi) iz. luna

illé (ile) iz. pelo

illàje (ilaje) iz. pelaje

illékixkur (ilekizkur) iz. persona de pelo rizado

illóba (iloba) iz. sobrino, -a, nieto, -a

illún (ilun) adj. oscuro, -a
illùnpe (ilunpe) iz. oscuridad
illùnoár (ilunabar) iz. atardecer
*illúndu, illùn, illùntzen (ilundu) ad. os-
$\quad$ curecer(se)
iltzé (iltze) iz. clavo
iltze (hiltze) iz. muerte

*ín, ì(n), ìtten (egin) ad. hacer

ínbeàr, ínbar (eginbehar) iz. quehacer

indár (indar) iz. fuerza

indárren (indarrean) adb. fuerte

*indártu, indàr, indàrtzen (indartu) ad. fortalecer(se)

inférnu, inpérnu (infernu) iz. infierno

ingúru (inguru) iz. alrededor

inpòrta, inpòrtik (inporta) ad. importar

intxàur (intxaur) iz. nuez

íntz (ihintz) iz. rocío

ínal (eginahal) iz. esfuerzo

iñáusi adb. en celo [la cerda] 
iñáuteri $g z t$, iñàuteri $z h r$, iñòte, ìñote $z h r$ (inauteri) iz. carnaval. ikus karnábal

*ínazi, ìnazí, ìnazten / ìnazí (eginarazi) ad. hacer hacer

*iñòiz (inoiz) adb. nunca (en interrogantes y negativas)

*iñòn (inon) adb. en ningún sitio (en interrogantes y negativas)

ińòne (z) (inon ere, inon ez) adb. en ningún sitio (en interrogantes y negativas)

*iñòr (inor) adb. alguien (en interrogantes y negativas)

ińóxente (inozente) adj. ingenuo

*ió, iò, iòtzen (igo) ad. subir

*ió, iò, iòtzen $z h r$ (eho) ad. moler

iól (igual) adb. igual

iórtzi, iórtzi, iórtzitzen / idórtzi (igurtzi) ad. frotar

ipár (ipar) iz. norte

ipàr-aizé (ipar-haize) iz. viento del norte

ipúrdi. ikus epúrdi

ipúrdiko. ikus epúrdiko

ipúr-masài. ikus epúr-masài

irábazi, irábaz, irábazten / iráozi (irabazi) ad. ganar

irábazle (irabazle) iz. ganador, -a

iràkin, iràkin, iràkitten (irakin) ad. hervir

iràlekú, iràlikú (iraleku) iz. lugar donde hay helechos

iràtze (iratze) iz. helecho

irátze-mèta (iratze-meta) iz. montón de helecho

iráo, iráo, iráotzen (igaro) ad. pasar

iràtsi, iràtsi, iràsten / itsàtsi (itsatsi) ad. pegar(se)

*iráuli, iràul, iràultzen (irauli) ad. volcar

iràulka (iraulka) adb. revolcándose

iràzki (iragazki) iz. colador

iréki. ikus eréki

irètsi, irès, irèsten (irentsi) ad. tragar

irí gzt (hiri) iz. ciudad

irìtar gzt (hiritar) iz. ciudadano

irín (irin) iz. harina

irríntzi (irrintzi) iz. irrintzi

irrìstalári, errìstalári (irristagarri) adb. resbaladizo, -a irrìstalátu, irrìstalá, irrìstalátzen / errìstalátu (irristatu) ad. resbalarse

irúgiñar (hirugihar) iz. tocineta

irúittu, irúi, irúitzen. ikus idúittu, idúi, idúitzen

irúroei (hirurogei) zenb. sesenta

isáts (isats) iz. cola

ìtti (igitai) iz. hoz

*ittó, ittò, ittòtzen (ito) ad. ahogar(se)

ittòtti (itogin) iz. gotera

ittúrri (iturri) iz. fuente

itsàtsi, itsàs, itsàsten (itsatsi) ad. pegar(se)

itsáso (itsaso) iz. mar

itsú (itsu) iz. / adj. ciego, -a

itsúmandoka $z h r$ (itsumandoka) iz. a la gallina ciega

itsúsi (itsusi) adj. feo,-a

*itsútu, itsù, itsùtzen (itsutu) ad. volverse ciego, -a

itxáfero (etxafuego, suziri) iz. cohete

itxé (etxe) iz. casa

*itxí, itxí, itxítzen / itxí, ìx, ixtèn (itxi) ad. cerrar(se)

itxúra (itxura) iz. aspecto

*ítz (hitz) iz. palabra

itzál (itzal) iz. sombra

*itzáldu, itzàl, itzàltzen (itzaldu) ad. oscurecer itzàli, itzàl, itzàltzen (itzali) ad. apagar(se)

itzéin, itzéi(n), itzéitten (hitz egin) ad. hablar

ixkànbilla, iskànbilla (iskanbila) iz. jaleo. ikus ixtillu

*ixíldu, ixil, ixiltzen (ixildu) ad. callar(se)

ixíll (isil) adj. callado, -a

ixílik(an), ixíllik(an) (isilik) adb. en silencio

ixilka (isilka) adb. a escondidas

ixkìn (izkin) iz. esquina

ixtànte (une) adb. momento

—ixtànten (berehala) adb. en seguida

ixtillu (istilu) iz. jaleo

ixtú (listu) iz. saliva

ixtú (estu) adj. estrecho, -a

izàera (izaera) iz. carácter

*izán, izàn, izàten (izan) ad. ser

izár (izar) iz. estrella

izáutu, izáotu. ikus ezáutu

izéba (izeba) iz. tía 
izén (izen) iz. nombre izérdi (izerdi) iz. sudor izkèra, ìzkerá $z h r$ (hizkera) iz. habla

izketa (hizketa) iz. habla

izlári (hizlari) iz. orador, -a

izórtu, izór, izórtzen (izorratu) ad. fastidiarse, estropearse izótz (izotz) iz. helada

iztér (izter) iz. muslo

iztún (hiztun) adj. hablador, -a

izú (izu) iz. miedo

izùti (izuti) adj. miedoso

*izútu, izù, izùtzen (izutu) ad. asustarse jatór (jator) adj. majo, -a

jáinko. ikus yáinko

jalèo (iskanbila) iz. jaleo

jangóiko (jaungoiko) iz. dios

jáuna (jauna) iz. señor

jáuna artú (jauna hartu) ad. comulgar

— jàun ta jábe. ikus yàun ta yábe

jaunártze (jaunartze) iz. comunión

jaurégi gzt. ikus yaurégi

jéla (jela) iz. hielo

jendàrme, yendàrme gzt (jendarme) iz. gen-

darme

jenérazio (belaunaldi) iz. generación jèrtse, jèrse, kèstre $z h r$ (jertse) iz. jersey

jìtu, jì, jìtzen (arakatu) ad. rebuscar jodé, joé (arraioa) interj. joder!

juérga (parranda) iz. juerga

juéz (juez) iz. juez

jùnta (junta) iz. junta
*juntátu, juntà, juntàtzen (juntatu) ad.
juntarse

\section{K}

kàbi (habi) iz. nido

kàfe (kafe) iz. café

kafésne, kàfesné zhr (kafesne) iz. café con leche

kàiku (kaiku) iz. 1 cuezo, cuenco de madera para recoger la leche 2 tonto, -a

kaiòla (kaiola) iz. jaula

kajói (tiradera) iz. cajón

káka (kaka) iz. excremento

kakàle, kakàie, kakàlle (kakagale) iz. ganas de cagar kakàlek eón, kakàiek eón, kakàllek eón ( $k a$ kaileak egon) ad. tener ganas de cagar

kakàletú, kakàle, kakàletzen / kakàietú / kakàlletú (kakailetu) ad. ponerse ganas de cagar

kakàlardó (kakalardo) iz. escarabajo

kakèri (kakeri) iz. diarrea

kakòntzi (kakontzi) adj. cagón, -ona

kalábaza (kalabaza) iz. calabaza

kále (kale) iz. calle

kalékume (kalekume) iz. persona de la calle / ciudad (peyorativo) 
kaléntura (sukar) iz. fiebre

kállu, káiu (kailu) iz. callo

kalté (kalte) iz. perjuicio

kamàmillú, kamámillu, kamàmiú, kamámiu (kamamila) iz. manzanilla

kamío $z h r$ (errepide) iz. camino

kamíon (kamioi) iz. camión

*kamústu, kamùs, kamùsten (kamustu) ad. desafilarse

kamúts (kamuts) adj. desafilado, -a

kankáiu, kankállu (kankailu) adj. grandullón, -ona

kànpo (kanpo) iz. fuera

kánta (kanta) iz. canto

kantári (kantari) adj. cantarín, -ina cantar

kantéra (harrobi) iz. cantera

kànto (kantoi) iz. cantón

kantói, kanttói (kantoi) iz. cantón pequeño

kàña (kanabera) iz. 1 caña 2 caña (de cerveza)

kapítalismo (kapitalismo) iz. capitalismo

karàitzarrí (kareharri) iz. (roca) caliza

karàkol (barraskilo) iz. caracol

karé (kare) iz. cal. ikus kisu

karétx (garatxo) iz. verruga

kárga (karga) iz. carga

karkàxa (karkaxa) iz. flema

karnábal (inauteri) iz. carnaval. ikus iñáuteri, iñòte

karnízeria (harakindegia) iz. carnicería

karràittu, karrài, karràitzen (garraiatu) ad. llevar

karráka (karraka) iz. 1 parlanchín 2 suciedad incrustada (en la piel...) 3 carraca

karràxi (garrasi) iz. grito

karrérik atère (moldatu) ad. arreglarse (con alguien)

kàrro (orga) iz. carro

karròtxa (aulkitxo) iz. silleta, carro para bebés

kaskáor (kaskagogor) adj. cabezota $-a$ kánposàntu (hilerri) iz. cementerio

*kantátu, kantà, kantàtzen (kantatu) ad.

kaskàsoi(ll), kaskàsoll (burusoil) adj. calvo,

kaskéta (kasketa) iz. rabieta

kásko (kasko) iz. 1 casco 2 cabeza 3 cima

kàso (kasu) iz. caso

kàso ín (kasu egin, kasu eman) ad. hacer caso

katàrro (katarro) iz. catarro

katàzka $z h r$ (lan) iz. trabajo

katé (kate) iz. cadena

katilu (katilu) iz. taza

kattàgorrí (katagorri) iz. ardilla

katú (katu) iz. gato

kaxkár (kaskar) adj. mediocre

kazkáorra (kazkabar) iz. granizo

kazùla (eltze) iz. cazuela

*ké (ke) iz. humo

kedár (kedar) iz. hollín

kéja (kexa) iz. queja

* kendú, kèn, kentzèn (kendu) ad. quitar

kéńu (keinu) iz. gesto, guińo

keríza. ikus geriza

kèstre. ikus jèstre

*ketátu, ketà, ketàtzen (ketu) ad. ahumar

kézka (kezka) iz. preocupación

${ }^{*}$ kezkátu, kezkà, kezkàtzen (kezkatu) ad. preocupar(se)

kidér (gider) iz. mango

kirkír, kirkíll (kilkir) iz. grillo

kìlo (kilo) iz. kilo

*kimá(tu), kimà, kimàtzen (kimatu) ad. podar

kímu (kimu) iz. brote. ikus muxkill

kìnto (kinto) iz. quinto, de la misma edad

kísu (gisu) iz. cal

kisúlabe, kixúlabe (gisu-labe, karobi) iz. calera

kisúskille (kisuskile) iz. calero, -a

kìto $z h r$. ikus ijito

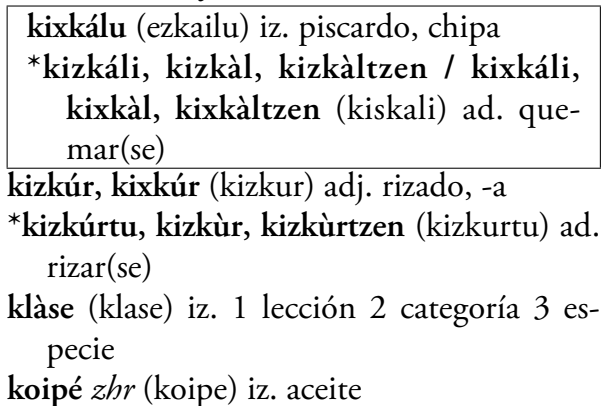


kòjo (kojo, herren) iz. / adj. cojo, -a *kolátu, kolà, kolàtzen (sartu) ad. colarse kolóka(n) (koloka) adb. inestable koltxói (koltxoi) iz. colchón kolùnpió, zàngulú $z h r$ (zabu) iz. columpio komèri (komeria) iz. enredo

komón (komun) iz. 1 retrete 2 cuarto de baño

konéju (untxi) iz. conejo

konfíantza (konfiantza) iz. confianza

konkór (konkor) iz. bulto, chepa

konpázio báteko $z h r$, konpáziora $z h r$ (konparazio baterako) adb. por ejemplo

*kontátu, kontà, kontàtzen (kontatu) ad. contar

kontèntu (kontentu) adb. contento, -a

(-en) kòntra (kontra) adb. contra

kòntrako eztàrri (kontrako eztarri) iz. tráquea

kontràrio (kontrario) iz. / adj. contrario, -a

kóntu, konòrte gzt (konorte) iz. conocimiento

kóntua galdú (konortea galdu) ad. perder el conocimiento

kóntu (kontu) iz. 1 cuento, asunto 2 excusa

*kóntu, kòn, kòntzen (eutsi, atxiki) ad. sostener (kóntu dó, kòn déila, kóntzen dío)

kónturatu, kóntura, kónturatzen (konturatu) ad. darse cuenta

kóntuz (kontuz) interj. ¡cuidado!

kópa (kopa) iz. copa

kopéta (kopeta) iz. frente

kopéteko (kopetako) iz. golpe dado o recibido en la frente korápiu, korápillu (korapilo) iz. nudo

kordíon (akordeoi) iz. acordeón

Kòrpus eún (Corpus egun) iz. día del Córpus

kóska (koska) iz. saliente

kósta (kosta) iz. costa

*kosté, kostè, kostètzen / ${ }^{*}$ kostá(tu) (kosta) ad. costar

kostilla (saihets) iz. costilla

kòtxe (kotxe) iz. coche

kotxé-kapòta (aulkitxo) iz. silleta cubierta, carro para bebés cubierta

koxkór (lokots) iz. mazorca desgranada de maíz

kòzka (hozka) iz. mordedura

kozkór, koxkór (koskor) adj. no grande - mutíl-kozkòr

*kozkórtu, kozkòr, kozkòrtzen / *koxkórtu (koskortu) ad. crecer

kréma (krema) iz. crema

krìston (kristoren) adj. impresionante

kuàdro (kuadro) iz. cuadro

kùku (kuku) iz. 1 cuco, cucú 2 visita $g z t$

kùkuka (kukuka) adb. al escondite

kukúrruku (kukurruku) iz. quiquiriquí

kukúso (arkakuso) iz. pulga

kulúska, kulúxka (kuluxka) iz. cabezada, siesta

kùrrilló (kurrilo) iz. grulla

kurrínka (kurrinka) iz. gruñido (del cerdo)

kuxíde (kuxidade) iz. desorden

kuxkúxero (kuxkuxero) adj. husmeador, -a

kutìi (gutizia) iz. antojo, capricho
Labàin (Labaien) iz. Labaien

labàn (laban) iz. cuchillo

labé (labe) iz. horno

lakátz (lakatz) adj. áspero, -a

*lakáztu, lakàz, lakàzten (lakaztu) ad. láku gzt (laku) iz. lago

lamí, lámi $z h r$ (lami) iz. sirena

làminá (xafla) iz. lámina

lámot. ikus láunbat

*lán (lan) iz. trabajo 
lanbró (lanbro) iz. bruma

*lanbrótu, lanbrò, lanbròtzen (lanbrotu) ad. enturbiar(se) (el cristal o el cielo)

lánda (landa) iz. campo

landáre (landare) iz. planta

langílle (langile) iz. / adj. trabajador, -a

lañó (laino) iz. nube

lapúr (lapur) iz. landrón, -ona

*lapúrtu, lapùr, lapùrtzen (lapurtu) ad. robar

lár (lahar) iz. zarza

larátz $z h r$ (laratz) iz. llar

laróei (laurogei) zenb. ochenta

larrí (larri) adb. con apuros

*larríttu, larrì, larrìtzen (larritu) ad. apu$\operatorname{rar}(\mathrm{se})$

larrú (larru) iz. cuero

larrú(a) yo (larrua jo) ad. follar

larrútu (larrutu) ad. despellejar

*lasá (lasai) adj. flojo, -a

lasái (lasai) adj. tranquilo, -a

lasáitasun (lasaitasun) iz. tranquilidad

*lasáittu, lasài, lasàitzen (lasaitu) ad. tranquilizar(se)

*lasátu, lasà, lasàtzen (lasatu) ad. aflojar

lastèrka (lasterka) adb. corriendo

lastèrka ín (lasterka egin) ad. correr

lastérra ín (laster egin) ad. correr

lastó (lasto) iz. paja

láta (lata) iz. lata

*látz (latz) adj. 1 áspero, -a 2 duro, -a

*láu (lau) zenb. cuatro

*láun (lagun) iz. 1 amigo, -a 2 persona

láunbat, láunbet, lámot, lámet (larunbat) iz. sábado

*láundu, làun, làuntzen (lagundu) ad. ayudar

láuntza (laguntza) iz. ayuda

làurden (laurden) iz. cuarta parte

*laxtér (laster) adb. pronto

leátz (legatz) iz. merluza

lége (lege) iz. ley

leió, leó (leiho) iz. ventana

*léittu, lèi, lèitzen (leitu) ad. leer

Léitza (Leitza) iz. Leiza

lejìa (lixiba) iz. lejía lekú (leku) iz. lugar

lèn (lehen) adb. antes

léno (lehenago) adb. antes

*lénbailen, lenbáilen (lehenbailehen) adb. cuanto antes

lènbizí, lèmizí (lehenbizi) adb. primero, -a

-lènbizíko, lèmizíko (lehenbiziko) adb. primero, -a

lèngusú (lehengusu) iz. primo, -a

-lèngusu própio (lehengusu propio) iz. primo, -a

-lèngusu ttíki (lehengusu txiki) iz. primo segundo, prima segunda

leór (lehor) adj. seco, -a

leòrte (lehorte) iz. sequía

*leórtu, leòr, leòrtzen (lehortu) iz. secar(se)

lepó (lepo) iz. cuello

-lepàzur, lepèzur (lepo hezur) iz. nuca

ler ín, ler ińa (leher egin) ad. extenuarse

*lértu, lèr, lèrtzen (lehertu) ad. reventar(se)

letáiñ (letagin) iz. colmillo

letxú, létxu $z h r$ (letxuga) iz. lechuga

leún (leun) adj. suave

*leúndu, leùn, leùntzen (leundu) ad. suavizar(se)

libru, libúru gzt (liburu) iz. libro

limói (limoi) iz. limón

liráiń (lirain) adj. esbelto, -a

lirdínga (lirdinga) iz. viscosidad

lizár (lizar) iz. fresno

lízta (listari) iz. hilo de bala

liztór (liztor) iz. avispa

lizún (lizun) iz. moho

*ló (lo) iz. sueño

*ló (lo) adb. dormido, -a

-ló-kulùxka (lo-kuluxka) iz. sueño ligero

-lo-zórro (lozorro) iz. sueño profundo

*ló in, lo ín (lo egin) ad. dormir

loále (logale) iz. sueño

loálek eón (logaleak egon) ad. estar sońoliento

loáletu, loále, loáletzen (logaletu) ad. adormilarse

lodí (lodi) adj. gordo, -a 
*lodíttu, lodí, lodítzen (loditu) ad. engordar(se)

*lói (lohi) iz. barro

lóre (lore) iz. flor

lótsa (lotsa) iz. vergüenza

lotsàti (lotsati) adj. vergonzoso, -a

*lotsátu, lotsà, lotsàtzen (lotsatu) ad. avergonzarse

*lotú, lotù, lotùtzen / lotzèn (lotu) ad. atar lotúra (lotura) iz. unión

loxíntxa (losintxa) iz. caricia loxórron (lozorro) adb. dormido, -a

lúma (luma) iz. pluma

*lumátu, lumà, lumàtzen (lumatu) ad. desplumar

*lúr (lur) iz. tierra

lùrpe (lurpe) iz. bajo tierra

lùrpetu, lùrpe, lùrpetzen (lurperatu) ad. enterrar

luzé (luze) adj. largo, -a

luzèra (luzera) iz. longitud madárikatu (madarikatu) adj. maldito, -a madárikatu, madárika, madárikatzen (madarikatu) ad. maldecir

madárikazio (madarikazio) iz. maldición

makéstu, makès, makèsten (makestu) ad. desafilar(se)

makéts (makets) adj. desafilado, -a

makilla (makila) iz. bastón

màkiná (makina) iz. máquina

màkulú (makulu) iz. muleta, báculo

*mài(a) (mahai) iz. mesa

màia $g z t$, màlla $z h r$ (maila) iz. nivel

maiákatu, maiáka, maiákatzen / mallákatu $z h r$ (mailakatu) ad. clasificar

maiátz (maiatz) iz. mayo

maibúru (mahaiburu) iz. presidencia (de la mesa)

maindìre, mandìre (maindire) iz. sábana

màistra $z h r$ (maistra) iz. maestra

màisu (maisu) iz. maestro

màiu $g z t$, màllu $z h r$ (mailu) iz. martillo

Máio iz. etxe izena

Màio iz. pertsona izengoitia

*máiz (maiz) adb. frecuentemente

maiztér, maxtér (maizter) iz. inquilino, -a

makál (makal) adj. débil *makáldu, makàl, makàltzen (makaldu) ad. debilitar

makár (makar) iz. legaña

makéts (makets) adj. desafilado, -a

makill (makil) iz. palo

*makúrtu, makùr, makùrtzen (makurtu) ad. agacharse

mál (magal) iz. regazo

málda (malda) iz. cuesta

maldízio (maldizio) iz. maldición

malèta (maleta) iz. maleta

malkér (malkar) iz. cuesta

malkértsu (malkartsu) adj. terreno abrupto

màlko (malko) iz. lágrima

mamí (mami) iz. miga

*mán. ikus (e)mán

mandàuli (mandeuli) iz. mosca borriquera

mandó (mando) iz. 1 mula 2 borrachera

màndo (mando) iz. mando

mandóa bóta (mandoa bota) ad. vomitar

manétu, mané, manétzen (maneatu) ad.

condimentar (la ensalada)

mantál (mantal) iz. delantal

mantàngorri, amóna mantàngorri (amona mantangorri) iz. mariquita

*manténdu, mantèn, mantèntzen (mantendu) ad. mantener(se) 
manténu (mantenu) iz. manutención mántso (mantso) adj. domesticado, -a mántso (mantso) adb. despacio

*mantsótu, mantsò, mantsòtzen (mantsotu) ad. 1 ralentizar 2 domesticar mańòntzi (mainontzi) adj. llorón, -ona màpa (mapa) iz. mapa marèo (mareo) iz. mareo marímotiko (mari-mutil) iz. marimacho marízikìn (mari-zikin) iz. mujer desaseada marmár (marmar) iz. 1 murmullo 2 refunfuño

— marmàrka (marmarka) adb. 1 murmurando 2 refunfuńando

- marmárren (marmarrean) adb. 1 murmurando 2 refunfuñando

màrra $g z t$ (marra) iz. raya

marráka (marraka) iz. grito, lloro

marránta (marranta) iz. ronquera

marrántatu, marránta, marrántatzen (ma-

rrantatu) ad. ponerse ronco, -a

marrói (marroi) adj. marrón

marrúskatu, marrúska, marrúskatzen $z h r$

(marruskatu) ad. frotar (la ropa)

màrtxa (martxa) iz. marcha, velocidad

marúri (marrubi) iz. fresa

masái, masáll $z h r$ (masail) iz. mejilla

masústa (masusta) iz. zarzamora

matálezur (matrailezur) iz. mandíbula

matálezùrreko (matrailezurreko) iz. bofetada

matéri (materia) iz. pus

*máts (mahats) iz. uva

mátsondo (mahatsondo) iz. vid

mátte (maite) adj. amado, -a

mátte izan (maite izan) ad. querer

*mattátu, mattà, mattàtzen (maitatu) ad. querer

maxkúri (maskuri) iz. vejiga

*mé (mehe) adj. delgado, -a

meár (mehar) adj. 1 estrecho, -a 2 delgado, $-a$

*meártu, meàr, meàrtzen (mehartu) ad.

1 estrechar(se) 2 adelgazar

mèdikú (mediku) iz. médico

menbrillu (irasagarra) iz. membrillo mendí (mendi) iz. montaña

mènpe (menpe) iz. control, dominio

mènta (menta) iz. menta

merézi izan (merezi) ad. merecer

mérke (merke) adj. barato, -a

${ }^{*}$ merkétu, merkè, merkètzen (merkatu) ad. abaratar(se)

mermélada (marmelada) iz. mermelada meséde (mesede) iz. favor

méta (meta) iz. montón (de hierba...)

metázirì (metaren erdiko makila) iz. palo en el centro del montón (de hierba...)

*métu, mè, mètzen (mehetu) ad. adelgazar

méza (meza) iz. misa

mézu (mezu) iz. mensaje

*mía, miàtxo (biga) iz. ternera

mikátz (mikatz) adj. amargo, -a

miko, míko gzt (moko) iz. pico

milàgro (mirari) iz. milagro

míllesker (milesker) iz. muchas gracias

mìna (meatze) iz. mina

míń (min) iz. dolor

míń (min) adj. amargo, -a

minbéra (minbera) adj. dolorido, -a

minbétu, minbé, minbétzen / binbétu

(minberatu) ad. dejar dolorido, -a

mìnbizí, minbízi (minbizi) iz. cáncer

mingáń (mingain) iz. lengua

mintzátu, mintzà, mintzàtzen $z h r$ (min-

tzatu) ad. hablar

míru (miru) iz. milano

miúra (mihura) iz. muérdago

mízka (itsaskorra dena) iz. algo pegajoso

*mizkátu, mizkà, mizkàtzen (mizkatu) ad. ponerse pegajoso

mizpíra (mizpira) iz. níspero

mízto (mizto) iz. 1 lengua viperina 2 agui-

jón

mobìda gzt (mugida) iz. movida

módu (modu) iz. modo

moldàketá gzt (moldaketa) iz. arreglo

*moldátu, moldà, moldàtzen (moldatu) ad.

arreglarse

momèntu (momentu) iz. momento

momórro (logale) iz. modorra

monóno, moñóńo (monono) adj. encanto 
montéro (basozain) iz. guarda forestal montói (montoi) iz. montón mòrdo (mordo) iz. montón mordóllo (mordoilo) iz. embrollo mordóska, mordóxka (mordoxka) iz. bastante

morkóts (morkots) iz. erizo (de las castańas) morrói (morroi) iz. ayudante mòro (mairu) iz. moro

moté (mote) interj. chaval

motél (motel) adj. 1 lento, -a 2 húmedo, -a (ropa) $z h r$

motél (motel) adb. despacio

${ }^{*}$ motéldu, motèl, motèltzen (moteldu) ad. aminorar (la velocidad)

motiko (mutiko) iz. niño

mòto (moto) iz. moto

motóts (motots) iz. moño

*mótz (motz) adj. corto, -a

mozkór (mozkor) iz. borracho, -a

*mozkórtu, mozkòr, mozkòrtzen (mozkortu) ad. emborrachar(se)

mozkóte (mozkote) iz. rechoncho, -a

mozórro, zomórro $z h r$ (mozorro) iz. 1 jóvenes que bailan de caserío en caserío y de casa en casa en carnavales 2 disfraz gzt

*moztú, moztù, moztèn (moztu) ad. cortar múa (muga) iz. límite

muànte $z h r$ (mugakide) iz. limítrofe

muárri (mugarri) iz. mojón, piedra divisoria

*múittu, mùi, mùitzen (mugitu) ad. mover(se)

mùki (muki) iz. moco

mukízu (mukizu) adj. mocoso, -a

múndu (mundo) iz. mundo

mùsiká (musika) iz. música

muskér, moskér $z h r$ (musker) iz. lagarto

muskíll zhr (muskil) iz. brote. ikus kimu

músu, múxu (musu) iz. beso

músu mán, múxu mán (musu eman) ad. besar

mutíll, motíll (mutil) iz. 1 novio gzt 2 joven (masculino)

mutilzar (mutilzahar) iz. solterón

mútu (mutu) adj. mudo

mutúr (mutur) iz. 1 morro 2 trozo

- mutùr-beltz

— mutúr-gorri

— mutúr-zuri

— txistór-mutùr

- mutúrluze

mutúrreko (muturreko) iz. morrazo

${ }^{*}$ mutúrtu, mutùr, mutùrtzen (muturtu) ad. enfadar(se)

muxár (muxar) iz. lirón nabári izán (nabari izan) ad. ser obvio nabáittu, nabái, nabáitzen (nabaritu) ad. notar(se)

*nài (nahi) iz. deseo

nài izán (nahi izan) ad. desear

náigabe (nahigabe) iz. disgusto

náigabe (nahi gabe) adb. sin querer

náiko (nahiko) adb. bastante, suficiente

nàita (nahita) adb. a propósito

nai ta nái ez (nahi eta nahi ez) adb. a la fuerza *nàiz (nahiz) junt. aunque

napár, nafár (nafar) iz. / adj. navarro, -a

narráts (narras) adj. no muy limpio

nási (nahasi) adj. 1 revuelto 2 complicado, -a 3 loco, -a gzt

*nási, nàs, nàsten (nahasi) ad. 1 mezclar(se) 2 confundir(se) 3 transtornar(se)

nàsketá (nahasketa) iz. 1 confusión 2 mezcla nastákatu, nastáka, nastákatzen (nahastekatu) ad. mezclar

natúra (natura) iz. naturaleza 
náusi (nagusi) iz. amo, -a

názka (nazka) iz. asco

nazkànte (nazkante) adj. asqueroso, -a

nazkárri (nazkagarri) adj. asqueroso, -a

nazkárrikeri (nazkagarrikeria) iz. asquerosidad

*nazkátu, nazkà, nazkàtzen (nazkatu) ad. 1 asquear(se) 2 hartar(se)

neár, niár $z h r$ (negar) iz. lloro

neár(ra) ín, niár(ra) ín $z h r$ (negar egin) ad.

llorar

neárgarri (negargarri) iz. lamentable

neàrti (negarti) adj. llorón, -ona

*nekátu, nekà, nekàtzen (nekatu) ad. 1 cansar(se) 2 hartar(se)

nekázari (nekazari) iz. labrador, -a. ikus basérritar

nekázaritza (nekazaritza) iz. agricultura

néke (neke) iz. cansancio

nekóso (nekoso) adj. trabajoso, -a

neré (nire) izord. mío, -a

— nerè idúriko (nire irudiko) en mi opinión

— neré ùstez (nire ustez) en mi opinión

neská (neska) iz. chica

neskáme (neskame) iz. sirvienta

neskàto (neskato) iz. palabra peyorativa para nombrar a una chica. Su uso está restringido a expresiones (neskatoa, neskatoa!)

neskátx (neskatx) iz. muchacha

neskàzar (neskazahar) iz. solterona neú, néu (negu) iz. invierno

*neútu, neù, neùtzen (negutu) ad. llegar el invierno

néune (neu) izord. yo mismo, -a

*neurtú, neùr, neurtzèn (neurtu) ad. medir

*ní (ni) izord. yo

niní (nini) iz. 1 pupila 2 bebé

*nóiz (noiz) adb. cuándo

nóizbitte, nóizpitte, nóizbette, nóizpette (noizbait) adb. alguna vez, en algún momento

nóizbeinka (noizbehinka) adb. de vez en cuando

nóiznai (noiznahi) adb. cuando quiera

nóiztsu (noiztsu) adb. más o menos cuándo

nóla (nola) adb. cómo

nólabitte, nólabette (nolabait) adb. de algún modo

nólanai (nolanahi) adb. de cualquier modo

*nón (non) adb. dónde

nó(n)bette, nó(n)bitte (nonbait) adb. 1 en alguna parte 2 expresión de asombro (nónbitte!)

nóra (nora) adb. adónde

nó(ra)bette, nó(ra)bitte (norabait) adb. a algúna parte

norbéra (norbera) izord. cada cual

nóski (noski) adb. 1 por supuesto 2 seguramente

nóskitxo adb. seguramente ñañár (ñañar) iz. pequeño, -a

ñàno (ñaño) iz. enano, -a

ñiñí (nini) iz. bebé ñó! interj. que indica asombro

ñòne, ñònéz. ikus iñòne(z)

ñòño iz. ñońo 
*oán, uán, oáñ, uáñ (orain) adb. ahora oàndik(an), uàndik(an), oàindik(an), uàin$\operatorname{dik}(\mathbf{a n})$ (oraindik) adb. todavía

óbe (hobe) adj. mejor

òbena (hoberena) adj. óptimo, -a

—òbenxkóna (hoberenetakoa) adj. uno, -a los, las mejores

odól (odol) iz. sangre

odólbildu (odolbildu) iz. coágulo [de sangre]

odòlki (odolki) iz. morcilla

oé. ikus ué

oei (hogei) zenb. veinte

*òik (hauek) erak. estos, -as

*òik (hauek) izord. éstos, -as

òintokó (oinetako) iz. calzado

*óittu, òi, òitzen (ohitu) ad. acostumbrar(se)

oittúra (ohitura) iz. costumbre

oká(b)ill (ukabil) iz. puño

okíll (okil) iz. pájaro carpintero

ókio (hobeki) adb. mejor

ól (ohol) iz. tabla
óla (horrela) adb. así
$\quad$-ólaxe(n), ólxe (horrelaxe) adb. así
$\quad$ mismo
óla (ola) iz. ferrería
òla, olátu (olatu) iz. ola

olíadura $z h r$ (oliadura) iz. extremaunción

olìo (olio) iz. aceite

olíotsu (oliotsu) adj. aceitoso

ollánda (oilanda) iz. polla [gallina]

olláor (oilagor) iz. becada

ollàr, oiàr (oilar) iz. gallo

ollàsko (oilasko) iz. pollo

ollàti (oilategi) iz. gallinero

olló (oilo) iz. gallina

olló-pikòr (oilo-ipurdi) iz. carne de gallina

*ón (on) adj. bueno, -a

ónbeste, óinbeste (hainbeste) adb. tanto(s), $-\mathrm{a}(\mathrm{s})$

ondár, onddár (hondar) iz. 1 resto 2 sedimento 3 arena ondàtu, ondà, ondàtzen (hondatu) ad. estropear(se)

ondó (ondo) iz. 1 al lado (de) 2 fondo

ondòre (ondore) iz. resaca

ondòren (ondoren) adb. después de

*ondú, òn, ontzèn / ondú, ondù, ondùtzen (ondu) ad.

onézkero (honezkero) adb. para ahora

ongárri (ongarri) iz. abono

ongárrittu, ongárri, ongárritzen (ongarritu) ad. abonar

óngi (ongi) adb. bien

\begin{tabular}{|l|}
\hline $\begin{array}{l}\text { ontto (onddo) iz. hongo } \\
\text { - onttò-beltz (onddobeltz) iz. boleto } \\
\text { negro }\end{array}$ \\
\hline ontz (hontz) iz. búho
\end{tabular}

ontz (hontz) iz. búho

ontzí (ontzi) iz. 1 recipiente 2 vajilla

ońáze (oinaze) iz. dolor

óñez (oinez) adb. a pie

opòr gzt (opor) iz. vacación

*ór (hor) adb. ahí

- orrára (horra) adb. ahí

*orá (hura) erak. aquel, aquella

*orá (hura) izord. aquél, aquélla, aquello

orákatu, oráka, orákatzen (txiki-txiki egin)

ad. hacer añicos

oràpe (gorape) iz. sotechado

orbél (orbel) iz. hojarasca

ordàn (ordain) iz. pago

ordàindu, ordàin, ordàintzen $z h r$ (ordaindu) ad. pagar

ordàinketa $z h r$ (ordainketa) iz. pago

òrdea (ordea) junt. pero

òrdez (ordez) adb. en vez de

órdu (ordu) iz. hora

ordù (ordu) adb. para cuando

órdun (orduan) adb. entonces

órduko (orduko) adb. 1 de entonces

2 para entonces 3 en cuanto 4 para cuando

oré (ore) iz. masa

Orèntzeró, Olèntzeró (Olentzero) iz. Olentzero 
orí (hori) adj. amarillo, -a

— oríxka (horixka) adj. amarillento

orí (hori) erak. ese, -a

orí (hori) izord. ése, -a, -o

—órtako (horretarako, horregatik) adb. 1 para eso 2 por eso

orín (orin) iz. lunar

orínal (pixontzi) iz. orinal

*oríttu, orì, orìtzen (horitu) ad. poner(se) amarillo

orítz $z h r$ (oritz) iz. calostro

órma (horma) iz. hielo

- ormáize (horma-haize) iz. viento helado

—ormázirí (horma-ziri) iz. estalactita de hielo

*ormátu, ormà, ormàtzen (hormatu) ad. helar(se)

*oróittu, oròi, oròitzen (oroitu) ad. recordar, acordarse

oròizi, oròizi, oròizitzen (oroitarazi) ad. hacer recordar

orràtz (orratz) iz. 1 aguja 2 alfiler. ikus yostòrtza

orráze (orraze) iz. peine

orràzkera (orrazkera) iz. peinado

orráztu, orráz, orrázten (orraztu) ad. peinar

orrí gzt (orri) iz. 1 hoja 2 página

orró (orro) iz. ruido

- orro báten (orro batean) adb. «con mucho ruido"

*órtz (hortz) iz. diente

— ortzá-makèts adj. que le falta algún diente
— ortzàundi adj. que tiene dientes grandes

ortzádar gzt (ortzadar) iz. arco iris. ikus estrèlla

osába (osaba) iz. tío

—osába ttíki (osaba txiki) iz. tío segundo

osásun (osasun) iz. salud

osín (osin) iz. ortiga

osó (oso) adj. entero, -a

osó (oso) adb. muy

ospél, gospél (ospel) iz. umbría, adj.

sombrío, -a

ostátu (ostatu) iz. alojamiento

ostéun (ostegun) iz. jueves

ostíel (ostiral) iz. viernes

ostíko (ostiko) iz. patada

ostó (hosto) iz. hoja

óstu, óstu, óstutzen (ostu) ad. robar

oté (ote) iz. argoma

oté (ote) si

otóitz (otoitz) iz. rezo

otórdu (otordu) iz. comida

otsó (otso) iz. lobo

ótz (hotz) iz. / adj. frío, -a

otzikara (hotzikara) iz. escalofrío

òzka. ikus kòzka

ozkàtu, ozkà, ozkàtzen (hozkatu) ad. morder

òzki (hozki) iz. dentera

ozpín $z h r$ (ozpin) iz. vinagre

*ozpíndu, ozpìn, ozpìntzen (ozpindu) ad. 1 enfriarse 2 avinagrar(se) $z h r$

oztù, oztù, oztèn / oztùtzen (hoztu) ad. enfriar(se) pàdi (pagadi) iz. hayedo

* pagátu, pagà, pagàtzen (pagatu) ad. pagar páke (bake) iz. paz

pála (pala) iz. pala
— palá sàio, pála sàio (pala saio) iz. sesión de pala

pantási $z h r$ (harrokeria) iz. fanfarronería

pantásioso $z h r$ (harro) adj. fanfarrón 
pañùlo (musuzapi) iz. pañuelo

páo (pago) iz. haya

papúr (papur) iz. migaja

—uí-papùr (ogi papur) iz. migaja de pan pár (barre) iz. risa

pardél (fardel) iz. paquete, hato de ropa

pàre (pare) iz. par
páre (pare) iz. lado, altura
parèja (bikote) iz. pareja
parét(a) (pareta) iz. pared
párra (barre) iz. risa

parrámurrìtx (irribarre) iz. sonrisa

parránda (parranda) iz. parranda

parrásta, palásta (parrasta) iz. chorro de lí-

quido

—úr-parràsta (ur-parrasta) iz. chorro de agua

párte (parte) iz. parte, pedazo

- (-en) pártez, (-en) pártetik (-en partez) de parte de

partídu (partida) iz. partido

* partíttu, partì, partìtzen (partitu) ad. par-

tir

pártz (bartz) iz. huevo de piojo

pasàtu, pasà, pasàtzen (pasatu) ad. pasar

pasmóbelar $z h r$ (pasmo-belar) iz. murajes

patáio $z h r$. ikus batáio

patáta (patata) iz. patata

páto (ahate) iz. pato

patríkera (patrikera) iz. faltriquera

pattál (pattal) 1 adb. enfermo, -a, débil

2 adj. malo (el tiempo)

* pattáldu, pattàl, pattàltzen (pataltzen, es-

kasten) ad. ponerse medianamente (del

enfermo)

pattár, patár (pattar) iz. aguardiente

pàtu, pà, pàtzen (paratu) ad. poner

pátxa (pagatxa) iz. hayuco

pátxa, páxa $z h r$ (mahaspasa) iz. pasa

páuso (pausu) iz. paso

paxáka. ikus baxàkarána

pazìntzi (pazientzia) iz. paciencia

Pázko (Pazko) iz. Pascua

pekátu (bekatu) iz. pecado

* pelátu, pelà, pelàtzen (pelatu) ad. calar(se), empapar(se) pèna (pena) iz. pena

* penátu, penà, penàtzen (penatu) ad. apenar(se)

péntsu, pénsu (pentsu) iz. pienso

pepita (pipita) iz. pepita

pérra (ferra) iz. herradura

perrátei (ferratoki) iz. lugar donde se ponen herraduras

* perrátu, perrà, perràtzen (ferratu) ad. poner herraduras

perrátzalle (ferratzaile) iz. herrador, -a

perrétxiku (perretxiko) iz. seta

perréxill (perrexil) iz. perejil

petátxu (petatxu) iz. petacho

pèto (peto) adj. auténtico, -a

petrál (petral) adj. insolente

* petráldu, petràl, petràltzen (petraldu) ad. volverse insolente

pétxu (bular) iz. pecho

petxùa (bularki) iz. pechuga [de pollo...]

pezói (titipunta) iz. pezón

pezpèra. ikus bezpèra

pikaró (pikaro) adj. pícaro, -a

pikárdia $z h r$ (pikardia) iz. picardía

piké (bike) iz. pez [substancia]

pikète (pikete) iz. palo para hacer cercados

píku, píko (piku) iz. higo

pikór (ale) iz. grano. ikus olló-pikòr

pilla (pila) iz. montón, abundancia

* pillátu, pillà, pillàtzen (pilatu) ad. amontonar

pillòta (pilota) iz. pelota

— pillóta-plàza (pilota-plaza) iz. frontón

pillótari (pilotari) iz. pelotari

pintúra (pintura) iz. pintura

píntza (pintza) iz. pinza

pínu (pinu) iz. pino

pipér (piper) iz. pimiento

pipèr ín gzt (piper egin) ad. hacer novillos

pipértu, pipèr, pipèrtzen (pipertu) ad. irri$\operatorname{tar}(\mathrm{se})$

pipí (pipi) iz. polilla

— pipík yó (pipiak jo) ad. apolillarse

* pisátu, pisà, pisàtzen (pisatu) ad. pesar

písu (pisu) iz. peso 
pitíto, pittílin (pitilin) iz. pito

píto (zakil) iz. pito

pittíka (pitin) iz. pizka

pitxér (pitxer) iz. jarra

pitxí (bitxi) iz. joya adj. elegante

pitxìtxi (pitxitxi) iz. minino

piúra (piura) iz. aspecto ridículo

píxa (pixa) iz. pis, orina

— píxusai, pixúsai (pixusain) iz. olor a pis

— pizázorro, pixázorro (pixazorro) iz. chorro de pis

pixàle (pixagale) iz. ganar de orinar

pixàletú, pixàle, pixàletzen (pixagaletu) ad. tener ganas de orinar

píxkanaka(-píxkanaka) (pixkanaka) adb. poco a poco

píxken-píxken (pixkana) adb. poco a poco

píxko (pixka) iz. poco

*pixòntzi, pixóntzi (pixontzi) adj. meón, -ona

pixtí (pizti) iz. bestia

* pixtú, pixtù, pixtùtzen / pixtú, pixtù, pixtèn (piztu) ad. encender

pizár, pixár (pizar) iz. pizca

pizár (bizar) iz. barba

pizkòr. ikus bizkòr

plánta (planta) iz. itxura, planta

plàtanó (platano) iz. banana

plàstikó (plastiko) iz. plástico

platèra (plater) iz. plato

pláza (plaza) iz. plaza

plazágizon (plazagizon) iz. hombre bri-

llante / desenvuelto ante el público

pòbre (pobre) iz. / adj. pobre

políki, pollíki (poliki) adb. 1 despacio

2 bien

polítt (polit) adj. bonito, -a

porlàn (porlan) iz. cemento

porrókatu (porrokatu) adj. empedernido, -a pórru (porru) iz. 1 puerro 2 porro $g z t$

posible (posible) adj. posible postúra (modu, tankera) iz. forma de estar, ser.

póte (pote) iz. 1 bote 2 salto

póteka (poteka) adb. saltando

potóto, potzótzo, pottóttina (alu) iz. coño

pòtrok, pottòiok (potroak) iz. testículos, huevos

pottóko (pottoko) iz. mońoño

pòxpoló (pospolo) iz. cerilla

pózik (pozik) adb. contento, -a

pránko. ikus fránko

prés (prest) adb. preparado, -a

préstu (prestu) adj. dispuesto, -a

prézio (prezio) iz. precio

prixíttu (frijitu) adj. frito, -a

* prixíttu, prixì, prixìtzen (frijitu) ad. freír

prodùkto, prodùktu $g z t$ (produktu) iz. producto

própio (propio) adj. carnal

pròpio (propio) adb. adrede

prozèso, prozèsu gzt (prozesu) iz. proceso

pukàdu (mokadu) iz. pincho

pùnta (punta) iz. punta

pùntu (puntu) iz. punto

pupú (pupu) iz. pupa

púrdi. ikus epúrdi

pùri-pùrin (furian) adb. a la moda

purrústi (purrustada) iz. refunfuño

púru (puru) iz. puro

púru (puru) adj. puro, -a

púska (puska) iz. cacho

— puskáleor, puxkaleor (puska lehor) iz. comida en frío

* puskátu, puskà, puskàtzen (puskatu) ad. romper(se), partir(se)

pùtre (putre) iz. buitre

*pútz (putz) iz. pedo sin ruido
- putzúsai (putzusai) iz. olor a pedo
pútzu (putzu) iz. pozo

puxká leòr (puska lehor) iz. comida en frío

puzkér (puzker) iz. pedo

puzkèrka (puzkerka) adb. echando pedos

— puzkérrusài iz. olor a pedo 
$\mathbf{R}$

ràdio (irráti) iz. radio

ràro (arraro) adj. raro, -a

ràsta (rasta) iz. rasta

ráza (arraza) iz. raza, casta, linaje

relòju (erloju) iz. reloj

rinózeronte (errinozeronte) iz. rinoceronte rìtmo (erritmo) iz. ritmo

roéri (drogeria) iz. droguería

Roèri iz. pertsona izengoitia

ròn (ron) iz. ron

ròk (rock) iz. rock

rùnba (rumba) iz. rumba saiàtu (saiatu) adj. que se esfuerza

*saiàtu, saià, saiàtzen (saiatu) ad. intentar sáinka $z h r$, záunka (zaunka) iz. ladrido

sáinka $z h r$, záunka (zaunka) adb. ladrando

— sáinka in $z h r$, záunka in (zaunka egin) ad. ladrar

sàio (saio) iz. intento

sakábanatu, sakábana, sakábanatzen (saka-

banatu) ad. dispersar(se)

sàke (sake) iz. 1 apetito 2 saque

sakón (sakon) adj. profundo, -a

sàla (sala) iz. sala

saldá (salda) iz. caldo

saldázu (saldatsu) adj. caldoso, -a

Saldís (Saldias) iz. Saldias

*saldú, sàl, saltzèn / saldú, saldù, saltzèn

(saldu) ad. vender

* sáll $z h r$ (sail) iz. grupo

salménta $g z t$, salmènta $z h r$ (salmenta) iz. venta

saltàtu, saltà, saltàtzen (saltatu) ad. saltar

sàlto (salto) iz. salto

saltzalle (saltzaile) iz. vendedor, -a

sálsa, sáltsa (saltsa) iz. 1 salsa 2 lío, enredo

salsétu, salsé, salsétzen / saltsétu (saltsatu)

ad. enredar, salsear

salséro, saltséro (saltsero) adj. salsero, -a

sàntu (santu) iz. adj. santo, -a

sapèlsa (zapelatz) iz. ratonero

*sár (sagar) iz. manzana sarátsa (sahats) n. sauce

sardé (sarde) iz. horca

sardìn, sardìn (sardina) iz. sardina

— sardintzar, sardìnzar (sardinzar) iz. sardina curada tratada de forma especial

sárdo (sagardo) iz. sidra

sardótei (sagardotegi) iz. sidrería

saré (sare) iz. red

sargóri, sargói $z h r$ (sargori) iz. bochorno

sarí gzt, sári zhr (sari) iz. premio

sarréra (sarrera) iz. entrada

sárri (sarri) adb. pronto, luego

— sárri arté (sarri arte) adb. hasta pronto

sárrondo (sagarrondo) iz. manzano

*sartú, sàr, sartzèn (sartu) ad. 1 entrar, meter(se) 2 llegar 3 incluir

— sartú-atère (sartu-atera) iz. visita breve

sasí (sasi) iz. zarza

- sasík artú (sasiak hartu) ad. cubrirse de zarzas

saskí (saski) iz. cesta

sasói (sasoi) iz. 1 época 2 juventud y fuerzas

- sasóiko eón (sasoiko egon) ad. estar fuerte

satór (sator) iz. topo

séa (sega) iz. guadaña

seáska (sehaska) iz. cuna

*séi (sei) zenb. seis

*séittu, sèi, sèitzen (segitu) ad. seguir 
séittun (segituan) adb. en seguida

* sekátu, sekà, sekàtzen (sekatu) ad. secar(se). ikus leórtu

sékula (sekula) adb. nunca (en frases negativas)

séme (seme) iz. hijo

sendábelar (sendabelar) iz. planta medicinal

*sendátu, sendà, sendàtzen (sendatu) ad. curar(se)

sendó (sendo) adj. fuerte

seníde $z h r$ (senide) iz. hermanos

seńále (seinale) iz. 1 señal 2 marca 3 indicio

séo (bilgor) iz. sebo

sèrio (serio) adj. serio, -a

sermói (sermoi) iz. sermón

sésio (sesio) iz. disputa, discusión

séuro, séuru (seguru) adj. seguro, -a

séuro, séuru (seguru) adb. seguramente

séuski, séuraski (segur aski) adb. seguramente

seùskiná (seguraskiena) adb. seguramente

sikàte (sikate) iz. sequía

silaba (silaba) iz. sílaba

silla (aulki) iz. silla

sillói (besaulki) iz. sillón

sòbra (sobera) adj. demasiado, -a

sòbra (sobera) adb. demasiado

*sói, sóll zhr (soil) iz. / adj. calvo, -a

soildù, sòil, soiltzèn / sòiltzen (soildu) ad.

1 volverse calvo, -a 2 talar

sóka (soka) iz. cuerda

soldádu (soldadu) iz. soldado

— soldádu yón (soldadu joan) ad. irse soldado soldá(d)uska (soldaduska) iz. servicio militar

sóńeko (soineko) iz. vestido

sóńu (soinu) iz. sonido

— sóńua yo (soinua jo) ad. tocar música

*sór (gor) adj. sordo, -a

sorréri (gorreri) iz. sordera

sorgín (sorgin) iz. bruja

sorgínkeri (sorginkeria) iz. brujería

sórta (sorta) iz. ramo

*sórtu, sòr, sòrtzen / sortzèn (gortu) ad. ensordecer

soró (soro) iz. campo

*sós (sos) iz. 1 dinero 2 moneda antigua $z h r$

sòto (soto) iz. cuadra

soziálismo (sozialismo) iz. socialismo

*sú (su) iz. fuego

suàngillú (sugandila) iz. lagartija

sué (suge) iz. serpiente

suègorrí (sugegorri) iz. víbora

suérte (suerte) iz. suerte

*sufríttu, sufrì, sufrìtzen (sufritu) ad. sufrir

súi (suhi) iz. yerno

sukàlde (sukalde) iz. cocina

*sumátu, sumà, sumàtzen (sumatu) ad. sentir, oír o percibir con los sentidos

*súr (sudur) iz. nariz

susára (susara) iz. estado de celo de la vaca

susára (susara) adb. en celo (la vaca)

*susáldu, susàl, susàltzen (susaldu) ad. ponerse en celo la vaca

sùsmo (susmo) iz. sospecha

* sútu, sù, sùtzen (sutu) ad. enfadar(se) (e)ta (eta) junt. y

tabérna (taberna) iz. bar

tabérnari (tabernari) iz. tabernero, -a

táka-tàka (taka-taka) iz. tacataca

talèntu (talentu) iz. talento tàlo (talo) iz. torta de maíz delgada y de forma circular

tanbór (danbor) iz. tambor

tankéra (tankera) iz. 1 parecido 2 aspecto

tantár (gogo) iz. cabezonería 
tantárra sartú ad. empeñarse

tànto (tanto) iz. tanto

*tapátu, tapà, tapàtzen (tapatu) ad. tapar

tartár (tartarika) iz. charlatanería

tartárren áittu (tartarrean aritu) ad. charlar

tàrte (tarte) iz. intervalo, medio

tàrteka (tarteka) adb. de vez en cuando

telèfono (telefono) iz. teléfono

télla, téia (teila) iz. teja

tellátu, teiátu (teilatu) iz. tejado

temóso (temoso) adj. obstinado, -a

tenóre (tenore) iz. tiempo

tenórez (tenorez) adb. a tiempo

tènte, ténte (tente) adj. / adb. tieso, -a

titáre (titare) iz. dedal

tití (titi) iz. teta

tìtu, tì, tìtzen (tiratu) ad. tirar

tipùla (tipula) iz. cebolla

titáre (titare) iz. dedal

tití (titi) iz. teta

tìtu, tì, tìtzen (tiratu) ad. tirar, estirar

tòka (toka) iz. toca [juego]

*tokátu, tokà, tokàtzen (tokatu) ad. 1 tocar (premio) 2 encontrar

tokí (toki) iz. lugar

tomàte (tomate) iz. tomato

tontór (tontor) iz. cima, pico

torí (tori) interj. toma

tórre (dorre) iz. torre

trába (oztopo) iz. estorbo

*trabátu, trabà, trabàtzen (oztopatu) ad. estorbar

tràgo (trago) iz. trago

tragóxka (tragoxka) iz. trago

trakéts (trakets) adj. torpe

tramànkulu (tramankulu) iz. armatoste

trápu (trapu) iz. trapo

tràste (traste) iz. / adj. trasto

trátu (tratu) iz. trato

tráza (traza) iz. parecido

trébe (trebe) adj. diestro, -a

*trén (tren) iz. tren

trenbíde (trenbide) iz. vía del tren

trésna $g z t$ (tresna) iz. herramienta, utensilio

tríku (triku) iz. erizo trípa (tripa) iz. tripa

tripàki (tripaki) iz. callos

tripá-orrok (tripa-orroak) iz. «ruidos de tripa»

tripàz gottí (tripaz goiti) adb. panza arriba tripótx (tripotx) iz. tripas del cordero

tríste (triste) adj. triste

trónku $z h r$ (tronko) iz. tronco. ikus enbor

tróntza (trontza) iz. tronzador [sierra]

trukàtu, trukà, trukàtzen (trukatu) ad. canjear

trùke (truke) iz. trueque

trumói (trumoi) iz. trueno

trumòika (trumoika) adb. tronando

ttántta (tanta) iz. chorro de licor que se echa al café

*ttattár (txar) adj. pequeño, -a, sin fuerzas. ikus txàr, txakár

ttíki (txiki) adj. pequeño, -a

- ttíkitan (txikitan) adb. en la infancia

— ttìkixkó (txikitxo) adj. demasiado pequeño, -a

*ttikíttu, ttikì, ttikìtzen / ttíkittu (txikitu) ad. empequeñecer(se)

ttípi-ttàpa (ttipi-ttapa) adb. a pasitos

ttírriki-ttárraka, ttirríki-ttarráka (ttirrikittarraka) adb. despacio

ttúku-ttùku iz. andar disimuladamente

tùtu (hodi) iz. tubo

txabói (xaboi) iz. jabón

txabòla (txabola) iz. chabola

txakár (txakar) adj. pequeño, -a, sin fuerzas

txalátan (zelatan) adb. espiando

txàlo (txalo) iz. aplauso

txàloka (txaloka) adb. aplaudiendo

txànda (txanda) iz. turno

txàndaka (txandaka) adb. a turnos

*txandátu, txandà, txandàtzen (txandatu) ad. turnar(se)

txanpínoi (txanpiñoi) iz. champiñón

*txár (txar) adj. 1 malo, -a 2 pequeño, -a, sin fuerzas

txárro (txarro) iz. jarra

txantxàngorri (txantxangorri) iz. petirrojo

txé (xehe) adj. triturado, -a 
txepétx (txepetx) iz. chochín

*txertátu, txertà, txertàtzen (txertatu) ad. 1 injertar 2 vacunar

txérto (txerto) iz. 1 injerto 2 vacuna

*txétu, txè, txètzen (xehatu) ad. triturar

txikíttu, txikì, txikìtzen (txikitu) ad. destrozar

txikízio (txikizio) iz. destrozo

tximísta (tximista) iz. relámpago

txìmitx $z h r$ (zimitz) iz. chinche

txímu (tximino) iz. mono

txìnga (txinga) iz. pesa de competición con asas que se lleva en cada mano y que se utiliza en las pruebas de fuerza

txìngo (txingo) adb. a la pata coja

txìngoká (txingoka) adb. a la pata coja

txingúrri (txindurri) iz. hormiga

txintxérri, zintzérri (zintzarri) iz. cencerro

txíntxo (zintzo) adj. formal

txiór, xiór (txigor) adj. tostado, -a

*txiórtu, txiòr, txiòrtzen / *xiórtu (txigortu) iz. tostar

txipíroi (txipiroi) iz. chipirón

txirrínta (gutizia) iz. antojo

txistór (txistor) iz. chistorra

txìstu (txistu) iz. flauta vasca, chistu

txìstuka (txistuka) adb. silbando

txistúlari (txistulari) iz. flautista, chistulari txitxí (haragia) iz. carne

txítxo (txita) iz. polluelo

txokàtu, txokà, txokàtzen (talka egin) ad. chocar

txokó, zokó (txoko) iz. rincón

txokòlte, txokólte (txokolate) iz. chocolate

txòpiñ (txopin) iz. hipo

txorákeri (txorakeria) iz. tontería

*txorátu, txorà, txoràtzen (txoratu) ad. enloquecer

txorí (txori) iz. pájaro

Txòri iz. pertsona izengoitia

txoró (txoro) iz. tonto, -a

*txorótu, txorò, txoròtzen (tontotu) ad. volver(se) tonto, -a

txòrro (txorro) iz. chorro

txotxólo (txotxolo) adj. zopenco

*txotxóldu, txotxòl, txotxòltzen (txotxoldu) ad. atontar(se)

txòzna gzt (txosna) iz. caseta de fiestas donde se sirven bebidas y comidas

txundár, txondár (txondar) iz. carbonera

— txundár-plaza, txondár-plaza (txondor-zulo) iz. lugar donde se hace la carbonera

txurí. ikus zurí

*tzár, zár (tzar) adj. malo, -a uál $z h r$ (uhal) iz. correa

*uáldu, uàl, uàltzen (ugaldu) ad.

*uán, uáñ. ikus oán

uára (ohara) iz. en celo [la perra]

uári (ugari) adj. abundante

uárittu, uári, uáritzen (ugaritu) ad. aumen-

tar

udá (uda) iz. verano

—udágiro

udàberrí (udaberri) iz. primavera udáre (udare) iz. pera

udàzken (udazken) iz. otoño

udó $z h r$ (hudo) iz. hurón

ué, oé (ohe) iz. cama

uèldek (uholdeak) iz. inundación

uéldu (ubeldu) iz. moradura

uí (ogi) iz. pan

—uí-kozkòr (ogi-koskor) iz. cuscurro

uká(b)ill. ikus oká(b)ill

*ukátu, ukà, ukàtzen (ukatu) ad. negar 
ukéndu (ukendu) iz. ingüento

*ukíttu, ukì, ukìtzen (ukitu) ad. tocar ukóndo, ukàlondó (ukondo) iz. codo

*umátu, umà, umàtzen (umatu) ad. parir úmetu, úme, úmetzen (umetu) ad. volver(se) niño, -a

úme (ume) iz. niño, -a

ùmegí (umeegi) adb. demasiado niño, -a

umíll (umil) iz. humilde

umóre (umore) iz. humor

úntz (huntz) iz. hiedra

*úr, úra (ur) iz. agua

*úr, úrra (hur) iz. avellana

urdài (urdail) iz. 1 jamón 2 estómago gzt

urdàiazpíko (urdaiazpiko) iz. jamón

urdàma (urdama) iz. cerda (con crías)

urdé (urde) adj. cerdo, -a

urdékeri, urdèkerí (urdekeria) iz. putada

urdín (urdin) adj. azul

*urdíndu, urdìn, urdìntzen (urdindu) 1 urdin kolorea hartu 2 lizundu

urkí (urki) iz. abedul

urpó (orpo) iz. talón

urrátu (urratu) adj. herida

*urrátu, urrà, urràtzen (urratu) ad. 1 rasgar

2 rasguñar 3 romper

urré (urre) iz. oro

ùrren, ùrrengo (hurren, hurrengo) adj. siguiente

urrí (urri) iz. octubre

urrí (urri) adb. poco, -a urrikittú, urrìki, urrìkitzén (urrikitu) ad. arrepentirse

urrítz (urritz) iz. avellano

urrúxa (urrixa) iz. / adj. hembra [sobre todo referido a animales domésticos]

urrúti (urruti) adb. lejos

urté (urte) iz. año
Urtèberri (Urteberri) iz. día de Año
Nuevo
urtébetetze (urtebetetze) iz. cumpleaños
*urtú, urtù, urtùtzen (urtu) ad. 1 derre-
tir(se) 2 diluir(se)

usái (usain) iz. olor

usàika (usainka) adb. oliendo

*usáittu, usài, usàitzen (usaitu) ad. oler

usó (uso) iz. paloma

ùste (uste) iz. fanfarronería

*ùste izan (uste izan) ad. creer

ùstea izan (ustea izan) ad. ser un creído, una creída

ustél (ustel) adj. podrido, -a

*ustéldu, ustèl, ustèltzen (usteldu) ad. pudrirse

úts (huts) iz. falta

úts (huts) adj. vacío, -a

*utzí, utzì, utzìtzen / uztèn (utzi) ad. dejar

utzíkeri (utzikeria) iz. dejadez

uztáill (uztail) iz. julio

uztárri (uztarri) iz. yugo

uztápe tràpu $z h r$ (izterpe trapuak) iz. compresa antigua

$\mathrm{X}$

xabál. ikus zabál

xakúr. ikus zakúr

xamàr (samar) adb. bastante

xamúr (samur) adj. tierno, -a

*xár. ikus zár

xártu. ikus zártu

xaú (sagu) iz. ratón

xaùxar, xàuxar (saguzar) iz. murciélago

*xaxátu, xaxà, xaxàtzen (xaxatu) ad. provo-

car (para la lucha) xelèbre (xelebre) iz. peculiar

xelébrekeri (xelebrekeria) iz. ocurrencia

xénda (xenda) iz. senda

xepél. ikus zepél

xérra (xerra) iz. 1 filete 2 loncha

${ }^{*}$ xerrátu, xerrà, xerràtzen (xerratu) ad. hacer rebanadas

xerrénda $z h r$ (zerrenda) iz. cosa, sitio o persona delgada, estrecha

xerrí. ikus zerrí 
xéxto (sesto) iz. cesto

xiàr-xiàr (zehar) adb. caminar por una ladera xílik(an). ikus ixílik(an)

ximél. ikus zimél

ximéldu. ikus ziméldu

ximíko. ikus zimíko

ximúr. ikus zimúr

xinìxmen (sinesmen) iz. creencia

xinìxtu, xinìx, xinìxten (sinistu) ad. creer

xiór. ikus txigór

xiórtu. ikus txigórtu xirímiri (zirimiri) iz. sirimiri

xíxa (ziza) iz. seta

xolómu (solomo) iz. lomo

xorrótx. ikus zorrótz

xóx. ikus sós

xoxó. ikus zozó

*xúr. ikus zúr

xurkéri. ikus zurkéri

xurrút. ikus zurrút

xuxén. ikus zuzén

xuxénbiden. ikus zuzénbiden

Y

yábe (jabe) iz. dueño

yái (jai) iz. fiesta

yáinko, jainko (jainko) iz. dios

yáio, yài, yàitzen (jaio) ad. nacer

yàki (jaki) iz. alimento

yákin, yáki(n), yákitten (jakin) ad. saber

yakínduri (jakinduria) iz. sabiduría

yakíntsu (jakintsu) adj. sabio, -a

yále (jale) iz. / adj. comilón, -ona

* yán, yà, yàten (jan) ad. comer

yanári (janari) iz. comida

yántzi (jantzi) iz. ropa

yántzi, yántzi, yántzitzen (jantzi) ad. vestir(se)

yàrrizi, yàrrizi, yàrrizitzen / yárrizi ( $\mathrm{ja}-$ rrarazi) ad. hacer poner

*yárri, yàr, yàrtzen (jarri) ad. poner, colocar

yása (jasa) iz. chaparrón

- eurí-yasa (euri-jasa) iz. chaparrón [OHARRA: Hitz elkartuetan agertzen da, batez ere, yasa. Eta hauetan, goranzko azentua galtzen $\mathrm{du}]$

yáso, yáso, yásotze (jaso) ad. recibir

yàun ta yábe, jàun ta jábe (jaun eta jabe) iz. dueño y señor

yaurégi $g z t$, jauregi $g z t$ (jauregi) iz. palacio yéki, yéki, yékitzen (jaiki) ad. levantarse yelóskor gzt (jeloskor) adj. celoso, -a yendàje (jendaila) iz. gentuza yendàrme. ikus jendàrme

yénde (jende) iz. gente

*yétsi, yès, yèsten (jaitsi) ad. bajar

yetsìera (jaitsiera) iz. bajada

*yétzi, yétzi, yèzten (jetzi) ad. ordeñar

*yó, yò, yòtzen (jo) ad. 1 pegar 2 tocar (un instrumento)

yoàre (joare) iz. cencerro

yoáregille (joare egile) iz. el, la que hace cencerros

yoéra (joera) iz. tendencia

*yokátu, yokà, yokàtzen (jokatu) ad. 1 jugar

(dinero, a deportes...) 2 actuar

yóko, yóku (joku) iz. juego

*yòn, yòn, yòten (joan) ad. irse

*yòn-tórri, yón-tòrri (joan-etorri) iz.
vuelta
$\begin{aligned} & \text { yón-trabòlta } g z t \text { (joan-etorri) iz. ida y } \\ & \text { vuelta }\end{aligned}$

yornál (soldata) iz. salario

yórra (jorra) iz. escarda

*yorrátu, yorrà, yorràtzen (jorratu) ad. escardar

yórren áittu (jorrean aritu) ad. escardar

*yósi, yòs, yòsten (josi) ad. coser

yostáiu, yostállu (jostailu) iz. juguete

yostàka (jostetan) adb. jugando

yostàka ibílli (jostetan ibili) ad. jugar

yostòrtza (jostorratza) iz. aguja (de coser).

ikus orràtz 
zabál (zabal) adj. ancho, -a

Zabàla iz. abizena

*zabáldu, zabàl, zabàltzen (zabaldu) ad. 1 ensanchar(se) 2 abrir(se)

zabàleró (zabalera) iz. anchura

zàbar $z h r$, zabár $z h r$ (utzia, alperra) iz.

1 abandonado, -a 2 perezosa, -o

zabárkeri (zabarkeria) iz. negligencia

*zabártu, zabàr, zabàrtzen (zabartu) ad. abandonarse

zái (zahagi) iz. odre

*zaildú, zàil, zailtzèn (zaildu) ad. 1 dificultar 2 curtir(se)

*záindu, zàin, zàintzen (zaindu) ad. cuidar

zakár (zakar) iz. basura

zakár (zakar) adj. bruto, -a

zakíll (zakil) iz. pene

záku (zaku) iz. saco

zakùto (zakuto) iz. alforja

zakúr, xakúr (txakur) iz. perro

zakúrkeri (txakurkeria) iz. jugarreta

zaláparta (zalaparta) iz. jaleo

zaldí (zaldi) iz. caballo

zaldiki (zaldiki) iz. carne de caballo

zaldiko (zaldiko) iz. potro

zále (zale) iz. / adj. aficionado, -a

*záll, zái (zail) adj. difícil

záma (zama) iz. 1 peso 2 borrachera

zanáori (azenario) iz. zanahoria

zàngulú $z h r$. ikus kolìnpio

*zanpátu, zanpà, zanpàtzen (zanpatu) ad. aplastar

*záñ (zain) iz. vena

zapàburú (zapaburu) iz. renacuajo

zapárra (zaparrada) iz. chaparrón

zapáta (zapata) iz. zapato

zapèl (txapel) iz. sombrero

zapéteko (zaplateko) iz. golpe

zápo (zapo) iz. sapo

*zár, zárra (zahar, tzar) iz. 1 viejo, -a

2 grande

zárpa (atzapar) iz. zarpa

zarpázu (zarpazu) adj. harapiento, -a zarrátatu, zarráta, zarrátatzen (zarratatu)

ad. desgarrar

zarréri (zaharreri) iz. vejez

zartán (zartan) iz. especie de sartén grande para asar castañas

zartàri (zartagin) iz. sartén

zartàtu, zartà, zartàtzen (zartatu) ad. agrietarse

*zártu, zàr, zàrtzen (zahartu) ad. envejecer

zartzáro (zahartzaro) iz. vejez

zatár (zatar) adj. feo, -a

zàto (zahato) iz. bota (de vino)

záun. ikus ezáun

záunka. ikus sáinka

záunka in. ikus sáinka in

zazpí (zazpi) zenb. siete

zéa (zera) iz. partícula que se usa cuando no se recuerda una palabra

zelái, xelái (zelai) iz. pradera

zéntzu (zentzu) iz. sentido

zepél, xepél (ergel) adj. atontado, -a, soso, -a zepél (zepel) iz. borrachera

*zepéldu, zepèl, zepèltzen (zepeldu) ad. 1 atontar(se) 2 emborrachar(se)

zerbèza (zerbeza) iz. cerveza

zeré (zeure) izord. tu

\begin{tabular}{l}
\hline zèro (zero) iz. cero \\
zéru (zeru) iz. cielo \\
zérra (zerra) iz. sierra \\
*zerrátu, zerrà, zerràtzen (zerratu) ad. \\
$\quad$ aserrar \\
zerrátu (zerratu) adj. cerrado, -a \\
zerràuts, serràuts (zerrauts) iz. serrín \\
zerrí (zerri) iz. cerdo, -a \\
zerríkiton, -a (zerrikiton) adj. cerdito, -a \\
zerríkume (zerrikume) iz. cría de cerdo \\
*zerríttu, zerrì, zerrìtzen (zerritu) ad. 1 en- \\
$\quad$ suciarse 2 volverse travieso \\
zértik(an) (zergatik) por qué \\
zéru (zeru) iz. cielo \\
zezén (zezen) iz. toro \\
ziàldo (ziraldo) iz. tambaleo \\
ziàldoká (ziraldoka) adb. tambaleándose
\end{tabular}


ziàr (zehar) adb. a través de. ikus xiàr-xiàr ziàrka (zeharka) adb. 1 transversalmente 2 indirectamente

ziàro (zeharo) adb. totalmente

zikín (zikin) adj. sucio, -a

*zikíndu, zikìn, zikìtzen (zikindu) ad. ensuciar(se)

zikínkeri (zikinderia) iz. suciedad zikíro (zikiro) iz. carnero castrado zikítu (zikiratu) ad. castrar zilbúr, xilbúr (zilbor) iz. ombligo zillár (zilar) iz. plata zimél, ximél (zimel) adj. marchito, -a *ziméldu, zimèl, zimèltzen / ${ }^{*}$ ximéldu (zimeldu) ad. marchitar(se)

zimèntuk (zimenduak) iz. cimientos zimíko, ximíko (zimiko) iz. pellizco zimúr, ximúr (zimur) iz. arruga zimúr, ximúr (zimur) adj. arrugado, -a *zimúrtu, zimùr, zimùrtzen / *ximúrtu (zimurtu) ad. arrugar(se)

zintzérri (zintzarri) iz. cencerro zìntzilik (zintzilik) adb. colgado, -a zíntzo (zintzo) adj. honesto, -a zìpatu, zìpa, zìpatzen (zipatu) ad. tropezar zipítz (zipitz) iz. ni pizca ziplo (ziplo) adb. de repente ziràba (ziraba) iz. lución zirbíll (txirlora) iz. viruta zirí (ziri) iz. palo pequeño zirìkatú, zirìka, zirìkatzen / xirìkatú (zirikatu) ad. 1 azuzar 2 hurgar

*ziríndu, zirìn, zirìntzen (zirindu) ad. 1 tener diarrea 2 manchar(se) con excrementos de ave

ziríń (zirin) iz. 1 diarrea 2 excremento de ave

zirìpurdi (zilipurdi) iz. voltereta

zírta (zirta) iz. salpicadura

zirtàtu (zirtatu) adj. salpicado, -a

zirtàtu, zirtà, zirtàtzen (zirtatu) ad. salpicar zizàre (zizare) iz. lombriz

ziztór. ikus txistór

zìztu (ziztu) iz. gran velocidad ziztu. ikus txistu

zokó. ikus txokó

—zokólaño (laino) iz. niebla

zòla (zola) iz. suela

zólda (zolda) iz. mugre

zópa (zopa) iz. sopa

zór (zor) iz. deuda

zorárri (zoragarri) iz., adj. maravilloso, -a

zorrí (zorri) iz. piojo

zorrízu (zorrizu) adj. piojoso, -a

zorró (zorro) iz. bolso, -a

zòrro (zorro) iz. chorro

zorrónka (zurrunga) iz. ronquido

zorrótz (zorrotz) adj. 1 afilado, -a 2 exigente

*zorróztu, zorròz, zorròzten (zorroztu) ad.

afilar

zortón, zurtón (zurtoin) iz. tallo

zozó, xoxó (zozo) iz. mirlo

zozókeri (zozokeria) iz. idiotez

zubí (zubi) iz. puente

Zubìta (Zubieta) iz. Zubieta

*zulátu, zulà, zulàtzen (zulatu) ad. agujerear zuló (zulo) iz. agujero

zúmu (zuku) iz. zumo

*zúr, xúr (xuhur) adj. tacaño, -a

*zúr zhr (zur) iz. madera

zurgín (zurgin) iz. carpintero, -a

zurí, xurí, txurí (zuri) adj. blanco, -a

zuríngo (zuringo) iz. clara de huevo

*zuríttu, zurì, zurìtzen (zuritu) ad. 1 blanquear 2 pelar

zurrùnbilló (zurrunbilo) iz. remolino

zurrùpi (zurrut) iz. sorbo

zurrút, xurrút (zurrut) iz. bebida

zurrútero, -a (zurrutero) adj. gran bebedor, $-\mathrm{a}$

zútik (zutik) adb. de pie

zuzén, xuxén (zuzen) adj. 1 recto, -a 2 correcto, -a

*zuzéndu, zuzèn, zuzèntzen / xuxéndu, xuxèn, xuxèntzen (zuzendu) ad. corre$\operatorname{gir}(\mathrm{se})$

zuzénbiden, xuxénbiden (zuzenbidean) adb. de por sí 


\section{LABURTUZ, GAZTE ETA ZAHARREN ARTEKO ALDEAK LEXIKOKO AZENTUERARI DAGOKIONEZ}

Zaharrenak diren aldakiek ezaugarri hauek dituzte (gutxienez, bat):

1. Gaur egun hain erabiliak ez diren praktikekin lotura dute: agá (haga), baé, bài (bahe), esnázu, ió (eho), larátz, oritz, pasmóbelar, udó...

2. Euskal Herriko mendebaldeko euskararekin lehian daude: arótz (herrero) vs. errementari, atzendu vs. ahaztu, bénpe(n), bénpeñen vs. behintzat, ebàtten vs. ebákitzen, ekusi vs. ikusi, eskuara vs. euskara, iuzki vs. euzki, mintzátu vs. hitzéin...

3. Azentu aldakortasunaren adibideak dira: bazkàri, bázkari / bazkàri, bàzkaldu / bazkàldu, bátezbèsteko / batázbesteko, Berá / Bèra, hizkera / hizkèra, létxua / letxùa, zintzatu / zintzàtu, kàfesne / kafésne, árpi / arpéi, laúndu / láundu, púre / purè, kanbiok / kànbiok...

4. Aldakortasun fonetikoa erakusten dute: pataio vs. bataio, paltso vs. faltso, yantza vs. dantza, epurmasall vs. epurmasai, maia vs. malla (maila), katazka vs. gatazka...

5. Euskara batuaren aurretik erabiltzen ziren hitzak dira, bizimodu berriaren esanahi eramale gehienetan: réunio vs. billéra, ofízina vs. bulégo, eskríbittu vs. idátzi, guardásola vs. atérkia, kaléfazioa vs. berógailua, kuàrtoa vs. géla...

6. Hitz zahar batzuk aldakortasunean daude erdal hitzekin: zàngulú vs. kolùnpio, koipé, gántz vs. grása...

\subsection{Goizuetako hitz bereziak}

Atal honetan, bereiz bildu nahi izan ditugu Goizuetako hitz berezitzat jotzen direnak. Gehienak adinduek bakarrik erabiltzen dituzte. Inguruetan ere esaten dira (edo ziren), baina nahiko eremu mugatuan erabiltzen direla uste dugu.

abáro $z h r$ (itzal) iz. sombra

adòki $z h r$ (adabaki) iz. petacho

apàparrútxa (zapaburu) iz. renacuajo

arràka (arrastaka) adb. a rastras

baldìmetán (baldinbaitere ${ }^{2}$ ) interj. ojalá!

berdántza $z h r$ (herenu gaua) iz. anteanoche

èriosúr, ériosúr (heriosuhar) adb. impetuosamente

gaurgéro $z h r$ (dagoeneko) adb. para ahora

iràzki $z h r$, iragazkí $z h r$, irákizki $z h r$ (iragazki) iz. colador

kándu $z h r$ (gandu) iz. 1 bruma 2 vaho de los cristales 3 catarata (en los ojos)

kaníta $z h r$, kanita $z h r$, kaniketa $z h r$ (ganibet) iz. cuchillo

katàzka $z h r$ (lan) iz. trabajo [vs. gatázka gzt (gatazka) iz. lucha]

kikara $z h r$ (kikara) iz. taza

2 Elhuyar hiztegian gipuzkerakotzat emana. 
kixkálu (ezkailu) iz. piscardo, chipa

koróko (borobil) iz. círculo pequeño

limèta ${ }^{3} z h r$ (botilla) iz. botella

manyáre ${ }^{4} z h r$ (manjatera) iz. pesebre

mórro, mórrotzen, mórrotu ad. zuhaitzei adarrak moztu, hauek indartu eta hazi-

tzean, mozteko, ikatz egiteko 5

pàzi $z h r$ (pazi) iz. olla

popóte (borobil) iz. bulto redondo

txiñàlka $z h r$, txiñèlka $z h r$ (txinalka) adb. en chancletas

txòil (txoil) adb. del todo

txikérdi $z h r$. txíkia litro laurdena zen, beraz, txikerdia litro zortzirena.

pèrrillá $z h r$ (gurpil) iz. rueda

ponpóllo iz. bulto

tantár iz. kaskagogorkeria

xaór (xahor) adj. pequeño, -a y flaco, -a

yáka $z h r$ (jaka) iz. cazadora

yón-trabòlta ${ }^{6} g z$ (joan-etorri) iz. ida y vuelta

zakèla $z h r$ (sakela) iz. bolsillo

zarrátera (zarratera) iz. desgarro (en ropa o telas)

zìpatu, zìpa, zìpatzen (zipatu) ad. tropezar

zipóta $z h r$ (kortxo) iz. corcho

\section{Hilabeteen izenak}

ilbéltza

otsábilla

mártxoa

apílla

maiátza / loráilla

garágarrilla ${ }^{7}$

uztáilla

aúztua

burúbilla $^{8}$ limeta

${ }^{3}$ Lehengo botila batzuen izena zen: http://oferta.deremate.com.ar/id=18378079_antiguas-botellas-

43.000 hiztegian manjatera ageri da: 1 . pesebre 2. cuadra de ovejas y terneros 3. trampas por donde se arroja al pesebre de la cuadra la comida del ganado.

Eta Elhuyar hiztegian manjatera (Ipar): pesebre, dornajo.

Nik Goizuetan, Loiarta baserrian jaso nuen, «aziendek jateko lekua» esanahiarekin.

5 Jesus Etxegiak esandako hitzak. Ez dut bestelako azalpenik bilatu. Pello Salaburuk «Baztango mintzoa» liburuan morrotu ematen du baina adiera honekin: azek eta arbiek beroagatik gaitza hartu (2005: 426).

${ }^{6}$ Ez dago oso zabaldua, kuadrila batek erabili izan du.

7 Hiztegi Batuan gipuzkerako ezaugarritzat emana da (Gip.). Elhuyar hiztegian, Gipuzkoa eta Goi Nafarroakotzat (G., GN.).

${ }^{8}$ Hiztegi batuan Iparraldeko ezaugarritzat emana da (Ipar). Elhuyar hiztegian Goi Nafarroa eta Iparraldekotzat (GN., Ipar.). 
urría

azároa

abéndoa

Hauek guztiak horrela adineko jendeak esaten ditu. Gazte batek euskara batuan bezala esango lituzke: urtárrilla, otsáilla, mártxoa, apirilla, maiátza, ekáiña, uztáilla, abúztua, iráilla, urría, azároa, abéndua.

\section{Grabazioak eta transkripzioak}

\subsection{Erabilitako teknika eta erabaki metodologikoei buruzko azalpenak}

\subsubsection{Laginketa}

Leku zehatz bateko hizkera aztertzean, normalean ez da lagin probabilistikorik erabiltzen. «Lagina populazioaren edo unibertsoaren zati adierazgarria da, eta bere ezaugarriak aztertuz, populazioari dagozkion emaitzak eta ondorioak lortzea ahalbidetzen du. Laginketa, beraz, laginak lortzeko prozedura da» (Juaristi 2003: 65).

Gizarte zientzietan erabili ohi den metodo honen helburua hau da: «Populazioa osatzen duten elementu guztiek laginean aukeratuak izateko probabilitate bera izatea» (Juaristi 2003: 67). Leku jakin bateko hizkera aztertu nahi denean, helburua hortik gertu dago, hizkera horren adierazgarri den lagina, adibidea, lortu nahi delako. Kontua da, dialektologian batez ere, ezaugarri jakin batzuk dituzten hiztunak hobetsi izan direla hizkera garbia eta lexiko aberatsa bilatu nahian, errealitatean hitz egiten diren aldaera guztiak jaso nahi izan ordez.

Gure ikerketan, bi helburu nagusi egon dira:

1. Goizuetako azentuaren ezaugarri nagusiak biltzea.

2. Azentu horrek izan ditzakeen gizarte aldaeren berri jasotzea. Horretarako, aldagai hauek hartu ditugu kontuan: emakume/gizon, gazte/heldu, herriko/baserriko. Beraz, Goizuetan hitz egiten denaren argazki bat egitea izan dugu helburu.

20 hiztun elkarrizketatu ditugu, honela banatuta (biztanleen arteko proportzioa kontuan hartu da lagina aukeratzerakoan):

- 10 emakume eta 10 gizon (biztanleen arteko proportzioa kontuan hartuz, bien arteko aldea dagoen ikusteko).

- Bakoitzetik lau 18-30 urte bitartekoak eta sei 60tik goitikoak (ahalik eta gazteenak eta ahalik eta helduenak, adinaren araberako aldea dagoen ikusteko) $)^{9}$.

— Baserritar eta herritarrak (bien arteko aldea dagoen ikusteko).

9 Horrela egiteko arrazoiak, ikertzailearentzat gazteen hizkera eta azentuera ezagunago izatea eta orain gazte direnak gero ere grabatzeko aukera egongo dela dira. 
Hizkera oso aldakorra den neurgaia da. Hizkera bat aztertzean, «ikertzailearen paradoxa»rekin topatzen gara beti; ikertu nahi duguna ikertu nahi izate hutsagatik, beragan eragina sortu eta aldatu egiten dugu. Beste hitz batzuetan, erreakzio arazoak egon daitezke:

La reactividad alude a la sospecha de que la persona que realiza el estudio o los métodos del propio estudio puedan influir en el modo de comportarse o de pensar de los sujetos observados, o modificarlos, en ausencia del investigador. Dicho de otra manera, existe el riesgo de que el propio acto de observación haga cambiar el comportamiento de los observados y de que, en consecuencia, los resultados de la observación sean engañosos (Manheim, J.B. eta Rich, R.C. 1988. Analisis político empírico. Métodos de investigación en Ciencia Política, Alianza Editorial, Madril, 23. or. in Juaristi 2003: 46. or.).

Hizkera biltzean, aldaketa hori sortzen duten aldagai nagusiak honakoak dira, gure ustez: mikro bat jartzea, elkarrizketatzaile arrotz batek galderak egitea, galdera itxiak eta kontestuz kanpokoak egitea. Horregatik, hizkera bat egoera naturalean egiten denean bezala biltzea zaila da eta laginketa probabilistikoak zaildu egin dezake grabaketa egokiak ziurtatzea.

Egoera hau izanik, laginketa aleatorioa egitea baztertu eta 20 hiztunak aukeratzerakoan, ezaugarri hauek zituztenak aukeratzea erabaki dugu:

- Mikro baten aurrean hitz egiteko arazorik ez izatea edo ohituak egotea (beste grabazio batzuk egin dizkietelako).

- Ixilak ez izatea.

— Elkarrizketatzailea ezagutzea edo gure erreferentzia izatea (familia ezagutzea...).

Zalantzarik gabe, elkarrizketatzailea bera herrikoa izatea lagungarria da hizkeraren naturaltasuna bermatzeko eta, aldaketaren bat dagoen kasuetan, identifikatzeko.

\subsubsection{Galdetegia}

Modu intuitiboan egin da. Helburua ez zen eduki jakin bat jasotzea, edukiontzia baizik. Zer esaten zen baino, nola. Horregatik, galderak errazak eta hiztuna eroso sentitzeko modukoak egitea izan da galdetegia osatzean izan dugun helburua. Hala ere, galderetan hiztunek aldaketari buruz dituzten usteez galdetzea pentsatu dugu, ikertzaileari berari hainbat fenomenoren inguruko pistak emanen zizkielakoan. Konparazio baterako, hizkerari buruzko aldeez eta bizimodu aldaketaren eraginaz galdetu diegu eta baita erantzun interesgarri franko lortu ere.

\subsubsection{Transkripzioak}

15 minutuko grabazioak izan dira. Hauek idazteko, transkripzio fonemikoa erabili da (/edan/) eta ez fonetikoa ([eðan]).

Alfabeto Fonetiko Internazionala erreferentziatzat hartuz, honako balio hauek erabili dira (IPA-k erabiltzen dituen ikurretatik diferenteak direnak bakarrik zerrendatuko ditugu): 


$$
\begin{aligned}
& -\mathrm{z}=/ \mathrm{s} / \\
& -\mathrm{s}=/ \mathrm{s} / \\
& -\mathrm{tz}=/ \mathrm{ts} / \\
& -\mathrm{ts}=/ \mathrm{ts} / \\
& -\mathrm{r}=/ \mathrm{r} / \\
& -\mathrm{rr}=/ \mathrm{r} / \\
& -\mathrm{x}=/ \mathrm{J} / \\
& -\mathrm{tx}=/ \mathrm{t} / \\
& -\mathrm{t}=/ \mathrm{c} / \\
& -\mathrm{j}=/ \mathrm{x} / \\
& -\mathrm{y}=/ \mathrm{j} / \\
& -\tilde{\mathrm{n}}=/ \mathrm{n} / \\
& -\mathrm{j}=/ \mathrm{x} / \\
& -\mathrm{ll}=/ \mathrm{K} /
\end{aligned}
$$

Transkripzio fonologikoetan erabili ohi ez diren ezaugarri batzuk erabili ditugu eta jarraian azalduko ditugu:

一,

Elkarren jarraian bi kakotx, esaldian goranzko doinu bat egin dela adierazteko erabili dugu. Goranzko doinu hau esaldia bukatzen denetan ere gertatzen da. Horregatik, batzuetan horrelako ikur multzoarekin topatuko gara, esaldia bukatzeko puntua jartzen dugulako, goranzko doinuarekin bukatu den esaldiaren ondoren: ,,.

Normalean komarik egongo ez litzatekeen kasuetan ere, bi koma aurkituko ditugu, goranzko doinu hori markatu nahian. Adibidez: Ta, gañera, beste polemika bat, yende askok saten duna da, Peña hori, dela Umore-Onako yendentzako bakarrikan.

$-\mathbf{h}$

Transkripzio fonologikoa denez eta Goizuetan hots hau ahoskatzen ez denez, normalena transkripzioan ez agertzea litzateke, hiztegian egin dugun bezala. Hiztegikoak, ordea, hitz solteak ziren eta, gainera, ondoan euskara batuko forma eman dugu, edozein zalantza argitzeko. Transkripzioaren kasuan, erabili egin dugu; hitz eta kontestu batzuetan egon daitezkeen anbiguedade eta iluntasunak argitzeko «h»a sartzea erabaki dugu.

Esan den bezala, grabazioetan erabili diren hitzak hiztegia osatzeko baliatu ditugu. Hiztegia osatzeko eta zalantza batzuk argitzeko baliatu ditugu elkarrizketa horiek. bana.

Hona segidan mutiko gazte baten eta emakume adindu baten elkarrizketaren zati

\section{0 urteko mutila}

Aurréneko gàldera, fièstari buruz. Zuk fièstak nóiztikan ezáutzen ttizo?

Pues, éztikit. Zazpí bat urtékin o ya hasí nitzan plázara arrímatzen,, ta ezti[ki]t, oáiń arte,, juérga ta juérga,,! 
Ta,, zuk nabáitzen al tzo aldéikan léngo fièstatatikan honára?

Nik uste,, oain géro ta yénde gútxio. Nóla kontròlak eta krìxtok,, eta nabáitzen da píxkoat yénde gútxio tòrtzen dela,, miño gànekon, lén bezàlatsú, bai.

Péñan bazkàrin atère izàndu ál tza?

Ez, sékula ez, éztit grázik ìtten.

\section{Ez? Zèba?}

Ézti[k]it, idúitzen tzít zakárkeri bát, èia sàn. Mozòrrotan atèko nítzake, biño Pènan éztit grázik itten. Éztikit zértikan miño. Alpérrikan míña hartzeko re pelìgroa bezèla, o... Eztikit.

Ordun, normala neska gútxio atètzera? O zértik uste zo eztiála atètzen?

Horráatik iól, e? Zakárkeri horréngatik. Ba! Oaiñ heldù dia, jenérazioa, gazté hoik. Bua! Oain dènak atéko día, séuru, aurtén. Hála idúitzen tzit.

\section{Zémat urtétsukok?}

Hamasei,, hamázazpi ittekó. Hórtik, hólatsukok izáin dia, bái. Hamásei-hamázazpi. Hemézortzikok e izángo dia,, pentsàtzen dut.

$[\ldots]$

Zuk bá al dikizo Zábi-dantzak, dántza horrek, ze kontàtzen dun, ze sinbólizatzen dun?

Izàten tzéla uste dut,, ikázkiń bat-o mendín bizi zena,, ta urtén bèhin herríra bajàtzen tzen,, ta mozkòrtzen tzenen,, neska guzik zikintzen,, o lastèrka harrápatu ta zikìntzen saiátzen tzéla, ez? Ta géro, makillakin yòka ìtten tzutén herrítika[n] beáli o. Éztikit,,! Hála úste béhintzat. Éno séuru biño.

\section{0 urteko emakumea}

Beste aldàketa men dó hizkèran. Euskèra, lénokoa ta uáingoa difénte àl da?

Ez, ez, Goizùtan,, ez. Goizùtan itten da,, léngo hizkùntza, zárra. Oañ, ník eztikit lótsangatik o zer dén,, neskàk yòten diá,, neskáme bétti. Yòten tzían, e? Oan ya horì re áttutzen ài dá,.. Eta, pasàtzen tzúten hillábete bat,, o bí han,, tórri honára,, eta heméngo hizkùntza éz ittetikan,, ìtten tzutén bèste hizkùntza horí: No sos? Nongo sa?

Nola?

E? Bèste hizkùntza. Guk ìtten dú zèta. Ta haiek berríz, ba, ese,,. Ya, heméngo èzten bezàla,, hizkùntza ìn. Hori, sartzèn zitén itsúsi zèla heméngoa,,. Guk hemèngok, bizì gànak,, ta ìtten dú dena iguál, denak.

$[\ldots]$ 
Náhi gabe re kanbitu itten tzo, e? Náhi gabe pix́kot, segun zéñekin.

Bai? Éztikít. Hítz bat o bèste battùzte, sàten ttuztènak, pai. $\mathrm{O}$, estudiatu dtèlakótz eskuàraz,, o battùzté. Miño, ez, ez. Hemèngok ya,, nik gure ùmekin-ta, illòbakin-ta heméngo hizkùntza itten dut,, ta gànekon e bai,,. Guk gén tartèn e bai,,.

Ta gaztètatikan étzo nabáitzen...

Ez, ez, ez, ez, ez. Oaiñ, batùa hori ikási dutènak o áittu dianak [...] hítz batzuk,, guk biño hókio sáin ttuzte, miño guk,, léngo hitzak,, hizkùntza,, gèhio dáuku. Miño,, dónu bérakin, béra, igual-igual. Badia, por ejemplo,, kórtxua. Ta lehengok etztén kórtxua sàten; zipóta.

$[\ldots]$

Nóla da?

Zakèla. Zakèla sartú,.. Zakèla. Hólokori bai. Horik attòn zarrak eta amon zárrokok. Horik, dena, hizkùntza déna... Guk ìtten ttu,, bàtzuk,, erdàraz bóta, sán. Hála áittu ttu,, yenden tàrten, miño eskuàra garbío da léngo zár horìna,,.

$[\ldots]$

Eta zuk, adíbidez, heméndikan kànpokori entéintzen al dizte, euskàraz ai diánen?

Bizkàitar horiri,, gútxi, biño gàñekon,, bai. Tolósan bezàlatsú ítten da Donóstin e, [mi] ño jatórro, hókio mén do,, Tolósa, Tolósa sàten’te, hizkùntza. Dena jun, jan.

\section{Ta Napárron ta Ipárralden ta hòitan,,?}

$\mathrm{Ni}$ gútxi ibíl naiz hòitan, miño yénde tòrtzen dénen nabáitzen da hizkuntzan. Lesákako yénde tòrtzen dela,, den'nabái zo,,! Hizkuntzan, hora nabái da déna! Alléka hórtakoa, Yántzi ta hòitakoa,, difénte da. Haik beste dónu bat duté.

\section{Oiártzungoa,?}

Oiártzungoa Goizùtan ióltsua. Bai. Gu, heméngo postúrakoa da,, Oiártzungoa, hizkuntza.

\section{Goizuetako azentu arauak}

\subsection{Orain arte esan dena}

Euskal azentuera hainbat ikerlariren aztergaia izan da; Azkue, Mitxelena, Jacobsen, Txillardegi, Hualde eta Gaminde izan dira, batez ere, euskal azentuaz aritu direnak. Dena den, hainbat gai aztertzeko daude eta aztertutako askotan ez dago adostasunik. Euskarak badu azenturik? Ze azentu? Eskualde bateko hiztunak beste batean kantari hitz egiten dutela esaten du. Baina orokorrean, «bai euskalari eta baita jende arruntaren artean ere, euskaraz azenturik ez dagoen ustea aski zabalduta dago oraindik ere» (Hualde 1997: 3). Hori dela eta azal dezakegu euskal azentuerei buruz orain arte egin den lan kopuru mugatua. Are mugatuagoa da Goizuetako azentueraz egin- 
dakoa. Atal honetan, Goizuetako azentueraz dauden lanak aztertuko dira, bakoitzaren puntu garrantzitsuenak nabarmenduz.

Zuzenean Goizuetako azentueraz hitz egin duten lanak gutxi dira: Gaminderena (1998), Zubirirena (2000), Hualde, Torreira eta Lujanbiorena (2008) eta Hualde eta Lujanbiorenak (2008, 2009 eta 2010). Badira Goizueta ingurua barne hartzen duten azterketa orokorragoak ere, baina hauetan esandakoak Zubiriren lanean laburbiltzen dira. Gamindek esandakoa ere bertan biltzen da. Hualde, Lujanbio eta Torreiraren artikuluan Goizuetako azentu arauez esaten dena Hualde eta Lujanbioren 2008ko lanean biltzen dira. 2010ekoan ez da deus berririk gehitzen. Horregatik, Goizuetako azentuerari buruz espreski esan eta aztertu direnak hiru artikulu hauetan biltzen direla esan dezakegu:

Zubiri, J.J. 2000. «Arano eta Goizuetako hizkera». In Zuazo, K. (arg.) Dialektologia gaiak. Gasteiz: Arabako Foru Aldundia (92-96. or.).

Hualde, J.I. eta Lujanbio, O. 2008. «Goizuetako azentuera». In: X. Artiagoitia eta J. A. Lakarra (arg.) Gramatika Jaietan: Patxi Goenagaren Omenez. EHUko Argitalpen Zerbitzua (341-358. or.).

Hualde, J.I. eta Lujanbio, O. 2009. "Goizuetako azentuaz zerbait gehiago: oharmena». In Gomez, R.; Etxepare, R.; Lakarra, J.A. Beñat Oihartzabali gorazarre Festchrift for Bernard Oyharçabal. ASJU 43 (1-2): 485-502.

\subsubsection{Zubiriren (2000) deskribapena}

Zubiriren artikuluan, Goizuetako azentuaren inguruan esandakoak biltzen dira, besteak beste. Hemen bildutakoaren arabera, Goizuetako azentu arauei buruz hitz egin duen bakarra Gaminde izan da eta hauek dira aipatutako ezaugarriak: azentu bereizgarria duela, azentua txertatzeko eremua hitz erroa dela eta azentua kokatzeko norabidea ezkerretik eskuinerakoa eta 2. silaban azentuatu ohi dela $([+2])$.

Behin ezaugarri hauek aipatuta, Zubirik Goizuetako azentueraren araua [+2] dela baieztatzen du (até), mailegu berrienetan ere hala dela esanez (sozialismo). Arau orokorretik ateratzen den beste azentu patroirik badago, ordea: lehen silaban azentuatzen diren hitzena. Hauek, Zubiriren esanetan, hitz markatuak dira. Hitz markatuen artean sartzen ditu azentua aurreko silabara igaro zaien hitzak (sinkoparen ondorioz, kontsonante baten galeraren ondorioz edo bi bokal berdin sinpletzearen ondorioz): (ah)árdi, z(ah)ár, s(ag)ár, s(ud)úr... Gehienek bi silaba dituzten arren, hiru eta laukoak ere badirela dio. Silaba kopuruka sailkatuta, Goizuetan topatu dituen hitz markatuen zerrenda egiten du ondoren.

Azentua deskribatzerakoan, bi eragin diferente hauek dituela esaten du:

1. Azentuaren kokaguneak hitzak bereizten ditu:

Azentuaren kokaguneak hitz pareak semantikoki bereizteko balio du. Adibidez, ári ('ahari') eta ari ('hari').

Aditzetan, indar berezia ematen du: normalean emán; baina éman, éman! Izen-adjektibo eta hitz elkartuak bereizten ditu: púska leór, puskáleor. 
2. Azentuaren kokaguneak ez ditu hitzak bereizten:

Hitz batzuek silaba batean nahiz bestean daramate azentua, hitz batetik bestera alderik ez badago ere. Azentu aldakortasunaren adierazgarri dira: bázkaldu/bazkáldu, létxulletxú, árpilarpéi, kánbiok/kanbiok, káfesnelkafésne.

Lan honen ekarpenen artean, honakoak azpimarratzen ditugu:

- Goizuetako azentu sistemaren proposamena egin izana: azentu orokorra [+2] da eta $[+1]$ azentua duten hitzek hitz markatuen multzoa osatzen dute.

- Hitz markatuen multzoa zerrendatzen hasi izana.

- Azentuaren balio bereizleaz ohartzea.

- Gure terminologian beheranzko doinua duten silabak ere silaba azentuduntzat hartu izana: txokólte, abitu, báso, Éurrik, góna, kábi, káiku, málko, málla, sóto, tárte, txistu, záto, ziztu ${ }^{10} \ldots$

- Singularraren eta pluralaren arteko diferentzia bokal luzeen jokaera berezi batekin lotzen du: Zubiriren arabera, izen guztiek azken silaban azentu bigarrenkaria hartzen dute. Azentu bigarrenkari hau desberdina da izen motaren arabera: batetik, bukaera kontsonantedunak eta bukaera bokaldunak (azentua azken silaban ez duten bukaera bokaldunak) multzokatzen ditu (gizón, itsáso) eta, bestetik, bokalez bukatu eta azentu nagusia bokal horretan daramatenak (asté). Izen mota horietan, bokal luzeak agertzen direla esaten du; 1 . multzoko izenetan, pluraleko forma luzatzen da (gizó:nak) eta 2. multzokoetan, singularreko forma (asté:k) (Zubiri 2000: 97).

Artikulu honetan, ordea, goranzko eta beheranzko doinuak ez ditu bereizten. Hau da, Zubirik kábi eta díru azentu berberarekin adierazi ditu. Gure ustez, doinu diferentea dute eta doinu diferentzia hori azentu bidez adieraz daiteke. Hemen aurkezten dugun lanean, beheranzko eta goranzko doinuak bereizteko ikur diferenteak erabili ditugu, Hualde eta Lujanbioren artikuluan (aurrerantzean H\&L 2008) egiten den proposamena aintzat hartuz. 4.1.2. puntuan hitz egingo dugu proposamen honetaz.

Bukatzeko, aipamen forma (citation form) erabiltzean, hitzak bigarren azentu bat hartzen du azken silaban, Zubirik adierazi bezala (soziálismoá). Azentu hori esaldimailakoa dela pentsatzeko arrazoiak badaude. Konparazio baterako, ondoren izan aditza esanez gero, bigarren azentu hori aditzak bereganatzen du (ikus Hualde, Lujabio eta Torreira 2008: 19 eta H\&L 2008: 344).

\subsubsection{Hualde eta Lujanbioren (2008) deskribapena}

Lan honetan, proposamen berri batzuk egiten dira Goizuetako azentuera deskribatzeko. Lehen atalean azaltzen denaren arabera, "Goizuetako azentuak bi alderdi bereizgarri ditu: kokagunea (lehen [+1] ala bigarren [+2] silaban), eta azentu mota (goranzkoa $[\mathrm{g}]$ ala beheranzkoa $[\mathrm{b}])$.

10 Zubiriren idazkera mantendu dut. Nik, beheranzko azentua adierazteko, azentu grabea (`) erabiliko nuke. 
Hau dugu lehen berrikuntza: azentu mota ezberdinak daude: goranzkoa eta beheranzkoa. «Lan honetan goranzko azentua azentu akutuarekin markatzen dugu ['] eta beheranzkoa azentu grabearen ['] bidez'.

Honen arabera, artikuluak azaltzen dituen bereizketa hauek daude (H\&L 2008: 341):

Esan bezala, bi elementuak, kokagunea eta azentu mota, bereizgarriak dira. Beraz, adibidez, ári 'ahari' eta arí 'hari' edo áte 'ahate' eta até 'ate' bereizten dituena azentuaren kokagunea da. Bestaldetik, arrántza 'astoaren arrantza' eta arràntza 'arrantzaleen arrantza', edo ámari 'amari' eta àmari 'amei' hitz pareek azentua silaba berberan daukate, baina azentu mota desberdinak. Azkenik, basó 'oihan' eta bàso 'edalontzi' edo iltzéa 'mailuaz erabiltzen dena' eta iltzea 'hiltzea' bai azentu motaz eta baita azentuaren kokaguneaz ere bereizten dira. Bi parametro bitar hauek lau konbinaketa ematen dizkigute:

(1) Goizuetako azentuaren tasun bereizgarriak

a. Goranzko azentua bigarren silaban $[+2, \mathrm{~g}]$ :

basó ('oihan') alába, ittúrri

b. Goranzko azentua lehendabiziko silaban $[+1, \mathrm{~g}]$ :

úme, áma, sékula

c. Beheranzko azentua bigarren silaban $[+2, \mathrm{~b}]$ :

eskòla, basèrri, alàbak (pl.)

d. Beheranzko azentua lehendabiziko silaban $[+1, \mathrm{~b}]$ :

bàso ('edalontzi'), àrima, kàfe, fábrika, àmak (pl.), lèngusu

Bi ezaugarri hauek ematen dizkiguten lau konbinaketak agian garbiago ikusten dira ondoko taulan:

\begin{tabular}{|c|l|l|}
\hline & $\begin{array}{c}\text { Goranzko azentua } \\
{[\mathbf{g}]}\end{array}$ & $\begin{array}{c}\text { Beheranzko azentua } \\
{[\mathbf{b}]}\end{array}$ \\
\hline$[+2]$ & besó, alába & eskòla, basèrri \\
\hline$[+1]$ & úme, áma & kàfe, àrima \\
\hline
\end{tabular}

Konbinaketa hauek lau multzotan banatzen dituzte azentu-sistema honetako hitzak. Beraz, azentuaren deskribapen honek Goizuetako hitzak lau azentu eredutan banatzea ahalbidetzen du.

Klase I: sg [+2, g], pl [+2, b]: gizón, mendi

Klase Ia: $[+2, \mathrm{~g}]$ singularrean eta pluralean: emákume

Klase II: sg [+1, g], pl [+1, b]: úme

Klase III: [+2, b] singularrean eta pluralean: belàrri

Klase IV: $[+1, \mathrm{~b}]$ singularrean eta pluralean: bàso 'edalontzi'

Azentu ereduen banaketa ere ikertu da artikulu honetan. Horretarako, oinarriaren silaba kopurua eta hitzaren jatorria hartu dira kontutan. Horren arabera, honako ondorioak atera dira izenen eta adjektiboen kasuan: 
- Patroi orokorra edo markatugabea Klase I/Ia da Goizuetan, gaur den egunean; euskal jatorriko hitz gehienak talde honetan sartzen dira eta mailegu luzeak ere eredu honetara egokitzen dira.

- Azentuak euskal jatorriko hitzak eta maileguak bereizteko balio du, nahiz eta irizpide zurrunik ezin formulatu. Joerak dira ageri direnak eta, orokorrean, beheranzko azentua duten hitzak mailegu berriak dira.

- Beste hiru azentu klaseak bereziak eta murritzak dira.

Ondorengo taulan laburbiltzen da klase bakoitzaren banaketa (H\&L 2008: 350):

\section{Azentu klaseen banaketa lexikala}

Klase I, $[+2, \mathrm{~g}]: \quad$ Orokorra edo markatugabea

Klase II, $[+1, \mathrm{~g}]: \quad$ a) Silababakarrak singularrean (adib. lúrra)

b) Mailegu zahar bisilabadunak (adib. páke)

c) Euskal jatorriko bisilabadun batzuk (adib. séme)

Klase III, $[+2, b]: \quad$ a) Batez ere mailegu hirusilabadunak (adib. tipùla) eta erdaraz azentua azken silaban duten bisilabadun batzuk (adib. Fermin)

b) Euskal jatorriko hirusilabadun batzuk (adib. belàrri)

c) Hitz eratorri batzuk (adib. izùtia)

Klase IV, $[+1, b]: \quad$ a) Mailegu bisilabadun berriak (adib. silla)

b) Mailegu hirusilabadunak, berri zein zaharrak (adib. ànima)

Horretaz gain, azentuaren funtzio morfologikoa azaltzen da artikulu honetan, singularretik pluralera azentu mota aldaketa baitago Klase I eta Klase IIn.

\section{Azentu aldaketa pluralean:}

$[\mathrm{g}] \rightarrow[\mathrm{b}]$ pluralean (baldintza: oinarriak hiru silaba edo guttiago badauzka)

Aldaketa hau beste egoera batzuetan ere aplikatzen da: adjektiboen superlatiboan, gehiegizko graduan eta eratorpen atzizki emankor batzuen kasuan (adib. - $t i$ atzizkia: beldür $\rightarrow$ beldùrti).

Hemendik, beste ondorio batzuk laburbildu ditugu:

- Silaba kopuruak azentu mota baldintzatzen du: Klase Iako hitzak dira gehienak.

- Hitz markatuak azentu-kokagunea 1. silaban duten hitzak eta beheranzko azentua dutenak dira (Zubiriren proposamenari beheranzko azentua duten hitzak gehitu dizkio). Azentu markatu hauen arrazoietan ere sakontzen da (H\&L 2008: 351). 
Hori guztia kontuan hartuta, artikuluko ondorioetako bat da Bizkaiko kostaldeko eta Goizuetako azentu sistemen artean korrespondentzia dagoela (H\&L 2008: 352):

\begin{tabular}{|lll|}
\hline $\begin{array}{l}\text { Goizueta } \\
\text { goranzko azentua } \\
\text { beheranzko azentua }\end{array}$ & $\rightarrow$ & $\begin{array}{l}\text { Bizkaiko kostaldea } \\
\text { azentugabea } \\
\text { azentuduna }\end{array}$ \\
\hline
\end{tabular}

Honi gehitzen badiogu singularraren eta pluralaren arteko azentu bereizkuntzan ere korrespondentzia hau topatzen dugula, argi dago bi sistemen artean lotura diakroniko bat dagoela, garai batean Gipuzkoatik iragaten zen zubia desagertu bada ere, gehienbat.

Hauek dira lan honetan azpimarratu nahi izan ditugun puntuak. Azentuera honen sisteman argitasun gehiago egin da, baina hemen ere ez da azentu sistema konplexu honen ikerketa agortzen, artikuluaren bukaeran esaten den bezala (H\&L 2008: 356):

Artikulu honetan erakutsi ditugun banaketa lexikalak eta Bizkaiko hizkerekiko korrespondentziek galdera asko pizten dituzte. Beste askoren artean, hurrengoak: zergatik dugu goranzko azentua mailegu bisilabadun zaharretan baina beheranzkoa berrietan (adib. míru eta mòro)? Zergatik beheranzkoa mailegu hirusilabadun zahar zein berrietan (adib. tipùla, banàna)? Nola azaltzen da hizkeren arteko korrespondentzia nagusia, Goiz. [b] = Bizk. [+azentuduna]?, etab.

\subsubsection{Hualde eta Lujanbioren (2009) deskribapena}

Artikulu honek Goizuetako hiztunek beren azentuari buruz zein oharmen maila duten aztertzen du. Goizuetako 40 hiztuni (gazteak/adinekoak eta emakumeak/gizonak modu orekatuan errepresentatuz) entzuten zutena guk prestatutako marrazkien bidez adierazteko eskatu zitzaien. Adibideetan, singularra/plurala doinuen arteko diferentzia (gizónak/gizònak) eta lexikoan agertzen direnak (arrántzalarràntza) biltzen ziren. Doinua egoki identifikatu zuten gehienek, gazteen kasuan bereziki.

Ondorio gisa, doinu-azentua mantentzen dela diogu lanean eta ez dirudiela galtzeko arriskuan dagoenik. Euskal Herria oro har kontuan harturik, euskaran desfonologizatze prozesu bortitz bat gertatzen ari da, eta egoera horretan, azpimarragarria da Goizuetan aurkitzen duguna. Hori bai, badirudi gazteek doinu lauagoa erabiltzen dutela, adinekoek bezainbesteko gorabehera gabea.

Artikuluaren bukaeran etorkizunerako egiteko bezala aipatzen da Goizuetako doinu-azentuzko bereizkuntza erabileran aztertzea, hizkera librean. Eta harrezkero egindako azterketa batean ikusi genuen zehaztapen bat egin beharra: «beheranzko» deitzen dugun azentu mota ahoskatzerakoan, esan behar da beti ez dela beherakada bat gertatzen. Doinuari dagokionez, doinu laua entzuten da batzuetan, baita adinekoen kasuan ere, eta hala erakusten dute espektrogramek. Terminologiarekin zehatzagoak izateko, beraz, Goizuetako azentueran "goranzko» doinua eta «beheranzkoa edo laua» ditugula esango genuke. 


\subsection{Ekarpen berriak}

Atal honetan, Goizuetako azentueraren inguruan egindakoa ikusita, hutsune batzuk betetzen saiatuko gara. 1. zatian gure ekarpen berriak azalduko ditugu eta 2.ean oraindik ere egiteko daudenak aipatuko.

\subsubsection{Silababakarren azentua}

Hiztegian * ikurraz adierazi ditugu hitz silababakarrak, azentu aldakorra dutela adierazteko. Dena den, azentua jarri diegu, beste hitzei azentua jartzeko erabili dugun irizpide berbera erabilita: ondoren - $a$ edo izan aditza jarrita hartzen duen azentua jartzea, neutroena delakoan. Horren ondorioz, beste kasuetan bezala, silababakar gehienei goranzko azentua jarri diegu (* ikurrari buruzko azalpen osoagoa Goizuetako azentu-hiztegia atalean dago, 2.2.2. puntuan).

Goranzko azentua daramaten hitz gehienak izenak eta adjektiboak dira. Oinarri silababakarreko izen eta adjektiboen berezitasunak Hualde eta Lujanbioren artikuluaren zati honetan biltzen dira (2008: 348):

Silababakarrekoak bereziak dira azentuaren aldetik. Hitzak singularreko atzizkia daramanean, goranzko azentua darama oinarrian (lúrra, lúrrari), eta pluralean, beheranzko azentua (lìrrak, lùrrari).

Absolutibo singularrean, izen silabakakarra bat artikulu/zenbatzailearekin, edo $a u$, ori, ora erakusleekin doanean, determinatzaileak ez dauka azenturik. Hau da, bat, $a u$, ori, ora flexio atzizki bezala portatzen dira (9a). Esan behar da, bat artikulua flexio atzizki bezala portatzea ez dela batere harrigarria, gauza bera aurkitzen baitugu zubereraz ere, adibidez: gizun baina gizúna eta gizún-bat. Erakusleak direla-eta, Zubirik (2000: 86) Aranoko hizkerarako erakusten duen bezala, erakusleak atzizkiak dira nor kasuan daudenean segmentu aldaketen ikuspegitik, eta hau azentueran ere ikusten da.

Aldiz, ondoan beste adjektibo edo modifikatzaile bat dugunean eta ondoko hitz honek gorako azentu daramanean, oinarri silababakarrak azentugabeak dira. Hau da, izen silababakarrak eta hurrengo hitzak azentu-eremu bakarra osatzen dute hemen ere, baina izenak azentua galtzen du (9b).

Azkenik, hurrengo adjektibo edo modifikatzaileak beheranzko azentua duenean, izen silabarrak goranzko azentua darama (9c).

(9) Silababakarrak
a. lúr-bat, lúrr-au, lúrr-ori, lúrr-ora
b. lurr-óntan, lur-txárra, lur-báten, lurr-óntako, lur-báteko, lur-gorría, ur- garbía
c. lúrr òitan 'lur hauetan', lúrr ònatan 'lur onetan'

Artikulu honen arabera, izen eta adjektiboek goranzko azentua daramate (9a) kasuan. Badira salbuespenak, ordea, (1)en ikusiko dugun bezala. Ondoren, beheranzko azentua duten adberbioen zerrenda eta goranzko azentua duten gainerakoen zerrenda egin dugu.

(1) Beheranzko azentua, adberbioak ez direnak:

$$
\begin{aligned}
& \text { *òik (hauek) } \\
& { }^{*} \text { òik (hauek) } \\
& { }^{*} \text { mài (mahai) }
\end{aligned}
$$


*nài (nahi)

nài izán (nahi izan)

*yòn, yòn, yòten (joan)

(2) Beheranzko azentua, adberbioak:

*àitz (hagitz)

*bài (bai)

*bèin, bèiñ (behin)

- beiñ o béiñ (behin edo behin)

- beiñ o bèste (behin edo beste)

*dèus (deus)

*èz (ez)

(3) Goranzko azentua, adberbioak:

*bárt (bart)

— bart arrátsen (bart arratsean)

* góiz (goiz)

* máiz (maiz)

*nóiz (noiz)

*nón (non)

*oán, uán, oáñ, uán (orain)

*ór (hor)

— orrára (horra)

(4) Goranzko azentua, zenbatzaileak:

*bát (bat)

*bí (bi)

— bítik báten, bíti páten (bien arteko aukeran)

*láu (lau)

*bóst (bost)

*séi (sei)

(5) Goranzko azentua, aditzak:

*ín, ìn), ìtten / ína (egin)

*yó, yò, yòtzen (jo)

Silababakarren artean beheranzko azentua daramatenak bi multzotan banatu ditugu: (1)en adberbioak ez direnak eta (2)n adberbioak. (1) multzoan, beheranzko azentua duen òik erakusle eta izenordainak zergatik duen azentu hori erraz azal daiteke: plurala da. Mài eta nài hitzen azentuaren azalpena, jatorrian bisilabadun izatea eta silababakar izatera pasatzean beheranzko azentua hartu izana izan daiteke. Zái (zahagi) sarrera azalpen honen kontraadibide da, hemen goranzkoa mantendu baitu. Yòn aditzari buruz ez dakigu ze azalpen eman (yòn $d a$ ); ezaugarri hauek dituen kasu bakarra dugu (aditz silababakarra, beheranzko azentua duena). Beharbada, antzeko adibide gehiago lortuta, azalpenen bat eman ahalko zaio.

(2)n, beheranzko azentua paratu diegun adberbioak bildu ditugu eta (3)n, goranzko azentua duten adberbioak. Multzo bakoitzak azentu diferentea izatearen 
azalpena honakoa da, gure ustez: (2) multzoko adberbioek ondoren izan aditza edo ez dute onartzen edo arraro egiten da (-a ezin zaie jarri, ezta (3)koei ere). Àitz adberbioak ez du ondoren izan aditza onartzen eta besteetan arraro egiten da. Beraz, adberbio hauek hiztegian zerrendatzean, bakarrik esanda duten azentuerarekin idatzi ditugu, beheranzkoarekin. (3) multzokoek, berriz, izan aditza atzetik onartzen dute eta, horrekin ahoskatzearen ondorioz, goranzko azentua hartzen dute. (2)koak bezala, bakarrik esanez gero, ordea, beheranzko azentuarekin ahoskatzen ditugu. Aldakortasun hau adierazteko markatu ditugu * ikurrarekin. Erantzuteke gelditzen zaiguna hau da: bakarrik esatean zergatik dute beheranzko azentua? Sintagma osoa hartzen dutelako?

(4) multzoan zenbatzaileak bildu ditugu. Hauek (3) multzoko adberbioak bezalakoak dira; ondoren izan aditza onartzen dute.

Aditzen azentuari buruz hurrengo atalean hitz eginen dugu zehatzago. Gainera, (5)en ikusten denez, adibide gutxi ditugu silababakarretan.

Hiztegia osatzen hasi ginenean baino argiago ikusten dugu orain silababakarren azentuera. Guztiek ez dute beti portaera bera eta azentu aldakorra dutela ohartu ginen. Hasieran zalantzak genituenez, ${ }^{*}$ ikurra jartzea erabaki genuen, gero, multzo zabalagoa izatean, orain egin duguna egin ahal izateko; ondorioak atera. Honakoak dira ondorio nagusiak:

- Gehienetan, azentu finkoa dutenik ezin dugu esan.

- H\&L 2008ren proposamena goranzko azentua daramaten hitzentzat baliagarria da:

(9) Silababakarrak

a. lúr-bat, lúrr-au, lúrr-ori, lúrr-ora

b. lurr-óntan, lur-txárra, lur-báten, lurr-óntako, lur-báteko, lur-gorría, ur-garbía

c. lúrr òitan 'lur hauetan', lúrr ònatan 'lur onetan'

- Baina beheranzko azentuarekin jarri ditugun izen hauek beheranzko azentua hartzen dute (9a)n: mài (mahai), nài (nahi); mài-bat, mài-au; nài-bat, nài -au. Ori eta ora-rekin gauzak aldatzen dira: mài-orí / mái-orí, mài-orá / mái -orá, nái-orí, nái-orá. Oso zaila egiten zaigu azken hauen azentuera finkatzea. Hau gehiago argitzen saiatu gara izen eta adjektiboen hitz multzoa aztertzean, 5.2. puntuan.

- Hiztegian azentua jartzeko erabili dugun irizpidearen arabera (ondoren - $a$ edo izan aditza jarrita hartzen duten azentua), silababakar gehienek goranzko azentua dute eta beheranzko azentua duten hitzen artean, adberbioak dira nagusi.

\subsubsection{Aditz jokatugabeen azentua}

Hiztegian, aditz sarrerak honela eman ditugu: aditz-partizipioa, aditz-oina eta aditz-izena.

Aditz-forma hauek ez dute aditz guztietan azentu eredu berbera. Batzuek aditzpartizipioa goranzko azentuarekin eta aditz-oina eta aditz-izena beheranzkoarekin 
ematen dute (1), beste batzuek hiruretan gorazkoa (2) eta beste batzuek hiruretan beheranzkoa (3). (1) multzoa * ikurrarekin adierazi dugu, hiru formek ez dutelako azentu berbera mantentzen. ${ }^{11}$

Hiru aditz-forma hauek hartzen duten azentuaren arabera, honako sailkapena dugu (hiztegiko $a$ hizkiko aditzekin osatu dugu taula hau):

(1) Azentu aldakorra duten aditzak

*áindu, àin, àintzen / áinddu (agindu)

*áittu, ài, àitzen (aditu)

*amíldu, amil, amiltzen (amildu)

*antzútu, antzù, antzùtzen (antzutu)

*arkáldu, arkal, arkàltzen (arkaratu)

*arrótu, arrò, arròtzen (harrotu)

*artú, àr, artzèn (hartu)

*asértu, asèr, asèrtzen (haserretu)

*así, às / así, astèn (hasi)

*asmátu, asmà, asmàtzen (asmatu)

*atzéndu, atzèn, atzèntzen $z h r$ (atzendu)

*autsí, àus, austèn / autsìtzen (hautsi)

*azí, àz, azìtzen (hazi)

*azmártu, azmàr, azmàrtzen / auzmártu (hausnartu)

(2) Goranzko azentua duten aditzak

abíxtu, abíx, abíxten (abisatu)

aiétu, aié, aiétzen / allétu (ailegatu)

aiéntu, aién, aiéntzen (aienatu)

akátu, aká, akátzen (akabatu)

aldátu, aldá, aldátzen (aldatu)

apróxtu, apróx, apróxten (aprobetxatu)

apúntu, apún, apúntzen (apuntatu)

arrápatu, arrápa, arrápatzen (harrapatu)

artésittu, artési, artésitzen (artesitu)

áttu, áttu, áttutzen (ahitu)

(3) Beheranzko azentua duten aditzak

airàtu, airà, airàtzen (airatu)

aizàtu, aizà, aizàtzen (haizatu)

altxàtu, altxà, altxàtzen (altxatu)

aòntu, aòn, aòntzen (agoantatu)

atère, atè, atètzen (atera)

àtzetu, àtze, àtzetzen (atzeratu)

àurretú, àurre, àurretzén (aurreratu)

11 Aditz-partizipioa azentu ezberdinekin esaten denetan ere, azentu aldakortasuna dagoela adierazi dugu * ikurraren bidez: *gàlezi, gàlezi, gàlezten / gálazi. 
Beti betetzen den orokortasuna denik ezin esan, baina azentu eredu bakoitzerako joera bat nabaritu dugu:

- (1) multzoa bi ezaugarri hauek betetzen dituzten aditzek osatzen dute:

a. Oinarrian duten hitzek goranzko azentua izatea

b. Azentu hori oinarriaren azken silaban egotea, hau da, aditzaren atzizkia itsasten den silaban

- (2) multzoa bi ezaugarri hauek betetzen dituzten aditzek osatzen dute:

a. Oinarrian duten hitzek goranzko azentua izatea

b. Azentu hori oinarriaren azken silaban ez egotea

Badirudi azentuak oroimena duela. Izan ere, arau hau jatorrian hitz luzeagoak ziren kasuetan betetzen da: aiétu (eta ez aiètu), jatorrian aiégatu zelako, segur aski. (2)ko hitz asko horrelako adibideez osatua dago: aiénatu > aiéntu, apróbetxatu > apróxtu, apúntatu > apúntu... Salbuespen bat badago, ordea: aldátu, aldá, aldátzen.

- (3) multzoa beheranzko azentua duten aditzek osatzen dute.

Hiru multzo hauek identifikatu eta gaia sakonago aztertzean, ohar hauek egin ditzakegu:

- (1) eta (3) multzoko aditz-izenak beheranzko azentuarekin paratu ditugu (àintzen, airàtzen) baina, galdegai-gunean egon edo ez, azentuera aldatzen zaiela ohartu gara:

a. Galdegaia denean, beheranzko azentuarekin agertzen da: àintzen dút / beti àintzen ái za; airàtzen da / abiona airàtzen ái da.

b. Esaldi markatugabea denean, goranzko azentua izaten du: nik áintzen dut; txoría àixa airátzen da.

- (3) multzoko partizipioarekin ere gauza bera gertatzen da (airàtu):

a. Galdegaia denean, beheranzko azentuarekin agertzen da: txoría airàtu (in) da.

b. Esaldi markatugabea bada, goranzko azentuarekin: txoría airátu da.

— Aditz-oinarekin gertatzen dena argitu gabe gelditzen zaigu: iruditzen zaigu normalean, hiztegian markatu bezala daramatela azentua baina testuinguruaren arabera aldatzen direla badakigu.

- (2) multzoko aditzek ez dute beheranzko azentua hartzen.

Arau konplikatu hauek denak sinpletzen dituen arau orokorrago bat dagoela iruditzen zaigu, baina ez dugu aurkitu.

\subsubsection{Adberbioen azentua}

Orohar, adberbioak izenak eta adjektiboak bezala azentuatzen dira. Hau da, adberbioetan ere, ohiko eredua azentua bigarren silaban eta goranzkoa edukitzea da: arrástan, aspáldi, bakárra, berándu, bestéla, betí, bidénabar, etzimu, gargéro... 
Lehen silaban azentuatutakoak ere badira: bárna / bárrena, bátten, bértan, búlken / búlkan, gábe, géio, géro, gértu, gútxi. Batzuk lehen silaba galdu dutenak dira eta, jatorriz, seguraski azentua bigarren silaban zutenak: áuro / áudo / abuido, béira, bétti, gótti, érki.

Beheranzko azentua dutenak ere badira. Hauen kasuan ere, azentua jartzeko beste hitzekin erabilitako irizpide berbera erabili da: $i z a n$ jartzea ( $-a$ ezin zaie jarri adberbioei). Silababakarretan gertatzen den bezala, hitz batzuek beheranzko azentua dute bakarrik esatean eta goranzkoa - $a$ edo izan aditza jartzean. Aldakortasun hau adierazteko * ikurra jarri zaie sarreretan. Adibidez:

— *atzó

Atzó zen bazkaria. Noiz? Atzò.

Beste batzuek beheranzko azentua dute beti. Horietako batzuk ondoren izan aditza jarri ezin zaien adberbioak dira (arrùnt, iñòiz, iñòn...). Horrelakoetan, askok beheranzko azentua dute. ${ }^{12}$

(1) Azentu aldakorra duten adberbioak (hiztegian * ikurrarekin markatutakoak): biár, béin, beréx, burúz, emén...

(2) Beheranzko azentua duten adberbioak: arrùnt, bezèla, bittàrten, debàlde, dexènte, erdizka, erènu, gànekon, ixtànte(n), iñoiz, iñòn, iñòr ${ }^{13} \ldots$

Orain arte aipatutako adberbioen artean, eratorpen bidez osatutakoak badira. Adberbioetan ere, eratorpen atzizkiek izen eta adjektiboetan sortzen duten efektu bera sortzen dute: azentua oinarriak daraman silaban mantentzeko joera dago eta batzuek oinarriaren azentu mota (goranzkoa edo beheranzkoa) mantentzen dute. Beste batzuek beheranzko azentua eransten dute. Jarraian, eratorpen atzizki batzuek adberbioen azentueran duten eragina azalduko dugu:

-era: beheranzko azentua jartzen du.

- aráu > aràbera

-ka: HIPOTESIA: oinarriaren azken silaba bada azentua daramana, beheranzko azentua jartzen dio $-k a$ atzizkiak. Bestela, oinarriak bere azentua mantentzen du.

- gáin, erdí, irául(i), ixíl > gàinka, erdizka, iràulka, ixilka

- arrástan, boláda, dardári, gótti, záunka > arrástaka, boládaka, dardárika, góttikoka, záunkaka

-ki: oinarriak duen azentua mantentzen du. ${ }^{14}$

- abil, gáitz, goxó, ón > abilki, gáizki, goxóki, óngi

- Beheranzko azentua duen oinarriari itsasten zaion adibiderik ez dugu topatu.

${ }^{12}$ Hemengo adibideetan ez ditugu silababakarrak sartuko, horietaz gorago hitz egin baitugu 4.2.1. puntuan.

13 Arrùnt, iñòiz, iñòn, iñòr ere * ikurra daramate hiztegian, aldakortasuna dutelako kasu hauetan: arrùnt aldaerarekin batera arrünten erabiltzen da eta iñòiz, iñòn, iñòr galderetan erabiltzen dira maiz eta goranzko azentua har dezakete.

${ }_{14}$ Izenak sortzen dituen $-k i$ atzizkiak, aldiz, beheranzko azentua jartzen die hitzei: odól $+-k i>$ odòlki, zerrí + -ki > zerriki... 
-(ra)ko: oinarriak duen azentua mantentzen du.

- betí, biár, etzi, ostéun > betíko, biárko, etziko, ostéuneko

- debàlde, erènu, ixtànte > debàldeko, erènuko, ixtànteko

-gi: beheranzko azentua jartzen du.

- aundi, bétti, gazté, gótti, ezkér > aundìgi, bèttigi, gaztègi, gòttigi, ezkèrregi

-(i)tti: goranzko azentua mantentzen du (ezin ziur jakin, dena den, atzizkia ihartua baitago).

- bé, gói > bétti, gótti

-ro: HIPOTESIA: oinarriaren azken silaba bada azentua daramana, beheranzko azentua jartzen dio -ro atzizkiak. Bestela, oinarriak bere azentua mantentzen du.

- aldí, asté, eún, illáete, udá, urté > aldìro, astèro, eùnero, udàro, urtèro

- Amábirjiñak, illábete > Amábirjíñero, illábetero

Oinarriak azentua azken silaban eduki ez arren, beheranzko azentua badu, -ro itsatsita ere hala mantentzen du:

- Ėurrik, udàzken > Eurriro, udàzkenéro

Udàberrí hitzarekin gertatzen dena berezia da, ikusten denez, bi azentu daramatzalako (hitz elkartuek bezala): udàberrí > udàberríro. Baina udazkenarekin gertatzen denaren pareko da, udàzken-ek azentu bakarra izan arren, birekin gelditzen baita azkenean: udàzkenéro.

-tik: oinarriak duen azentua mantentzen du.

- atzó, betí, biár > atzótik, betítik, biártik

- afalondo, erènu > afalondótik, erènutik

-xio (-xeago): oinarriak duen azentua mantentzen du, baina beheranzko azentua duen oinarriarekin -xio berak hartzen du goranzko azentua: $-x i o^{15}$

- berándu, bétti, gótti, ondó > beránduxio, béttixio, góttixio, ondóxio

- màisu, ijìto > màisuxio, ijìtoxío

-xko: beheranzko azentua jartzen du.

- berándu, bétti, gótti > berànduxkó, bèttixko, gòttixko

Hitz elkarketa bidez osatutako adberbioek, beste hitz elkartuetan gertatzen denaren kontra, beheranzko azentua dute maiz (ikus hitz elkarketei buruz esandakoa, 6. atalean):

- afalondó, afalaurré, bittàrten, festàurre, gosàlaurré, gainbèra

- bixi-bixi (bixi), bizi-bizi (bizi), etsi-etsin

- berè gisá, buruz bettí, dèusé(z)

- 1. osagaiak ez darama beti azentua: beiñ o bèiñ, beiñ o bèste, emen bértan

15 Honek gure hipotesietako bat oroitarazten du: beheranzko azentua daraman silabatik bi eskuineragoko silabak goranzko azentua «eskatzen» du. 


\subsubsection{Juntagailuen azentua}

Juntagailu gutxi bildu ditugu orokortasunak atera ahal izateko. Nabaritu duguna batzuek azenturik gabeak izatea da. Hauek dira hiztegian zerrendatu ditugunak, azentuaren arabera sailkatuak:

- Azentudunak goranzko azentuarekin: aléia, bénpe(n), bénpeñen

— Azentudunak beheranzko azentuarekin: àle, bàizikan, gàñera, nàiz

-Azentu gabeak: biño / miño, (e)ta, (ed)o

\subsubsection{Pertsona eta herri izenen azentua}

Azterketa sakona egin ez badugu ere, hemen ere, beste hitzetan aurkitu ditugun eredu desberdinak daude. Hara hemen adibide batzuk, herri izenak oinarri hartuta eta Hualderen sailkapen eredua erabilita:

- Klase $I[+2, \mathrm{~g}]$ (azentua bigarren silaban eta goranzkoa dutenak): Arántza, Berá (zhr), Donósti, Errénteri, Ittuiin (Ituren), Saldis

-Klase II [+1, g]: Gáintza, Léitza, Yántzi (Igantzi)

-Klase III [+2, b]: Aràno, Beràstegi, Bè̀te (Beruete), Ernàni, Goizùta, Zubita

-Klase IV $[+1, \mathrm{~b}]$ : Bèra (gzt)

Pertsona izenen kasuan ere, lau klaseetako izenak aurki ditzakegu. Hala ere, beheranzko azentua dutenak nagusi dira:

-Klase I [+2, g]: Axier, Fermin, Fidél, Miél, Olátz, Oxéntonio, Tomás, Joxé

-Klase II [+1, g]: Juán, Jón

—Klase III [+2, b]: Aitziber, Amàia, Andòni, Enèko, Enèritz, Fernàndo, Iñìgo, Itsàso, Maiàlen, Màri, Naiàra, Oibàna, Saiòa, Yosèba

—Klase IV [+1, b]: Gòrka, Yòne, Yòsu, Làxaro, Mikel, Nòra, Pàblo, Ròsa, Urtzi

Hualde eta Lujanbioren artikuluan (2008: 345) Klase I-eko Fermin, Fidèl eta Olàtz beheranzko azentuarekin daude. Hemen goranzkoa jarri diet, hiztegian erabili dugun irizpidea aplikatuta, ondoren da jarrita, alegia, goranzko azentua hartzen dutelako.

Atal honekin bukatzeko, azentuagatik bereizten diren izen arrunt eta propioen inguruan mintzatu nahi dugu. Hona hemen aurkitutako pareak edo hirukoak, hiztegian bildu bezala:

béra (hura, bera) izord. 1 el, élla, éllo 2 izord. el, lo mismo, la misma

berá (bera) adj. blando

Berá $z h r$, Bèra gzt (Bera) iz. Vera de Bidasoa

erróta (errota) iz. molino

Erròta iz. pertsona izengoitia

màiu $g z t$, màllu $z h r$ (mailu) iz. martillo

Máio iz. etxe izena

Màio iz. pertsona izengoitia

roéri (drogeria) iz. droguería

Roèri iz. pertsona izengoitia 
txorí (txori) iz. pájaro

Txòri iz. pertsona izengoitia

zabál (zabal) adj. ancho, -a

Zabàla iz. abizena

Hitz batzuek berez dute beheranzko azentua (tàlo) eta, izen propioa denean ere, hala mantentzen dute (Tàlo). Salbuespen bezala, adibide hau aipatu behar: tximista $=$ Tximista .

Salbuespenak salbuespen, arau orokor bat badagoela dirudi: izen arruntak goranzko azentua du, pertsona izenak beheranzkoa. «Plural accent rule» delakoaren antzekoa formulatu dezakegu hemen ere: ${ }^{16}$

Goranzko azentua $\rightarrow$ beheranzko azentua pertsona izenetan

J.J. Xubirirekin izandako solasaldi batean, arau hau baieztatzeko beste adibide bat eman zidan: baserri izenak eta baserri horretako pertsona izenak azentuaz bereizten dira. Hemen ere, pertsona izena da beheranzko azentua daramana: Alkáso / Alkàso, Untxári / Untxàri, Sarrán / Sarràn, Domiña / Domiña...

\subsubsection{Azentuak mugagabe eta pluralean}

Orain arteko lanetan ez da adierazi Goizuetan mugagabea nola esaten den. Aztertu dugunaren arabera, mugagabea singularrarekin doa; hau da, biek goranzko azentua dute. Pluralarengandik azentuarekin bereizten dira, esan dugunez, pluralak beheranzkoa baitu (lau silabatik beherako oinarridun hitzetan). Hona hemen adibide batzuk:

- Mugagabea:

- Edózin itxétan

- Hiru gizónakin kúsi dut (ezagutzen ez ditudan hiru gizonekin. Gazteleraz, la he visto con tres hombres)

- Hiru gizónan ahòtsak áittu ttut (ahots ezezagunak dira. Gazteleraz, he oido la voz de tres hombres)

- Plurala:

- Hiru gizòn kúsi ttut

- Hiru gizònakin kúsi dut (hiru gizon horiekin. Gazteleraz, la he visto con los tres hombres)

- Hiru gizònan ahòtsak áittu ttut (gizon horien ahotsak dira. Gazteleraz, he oido la voz de los tres hombres)

${ }^{16}$ Jatorrizko araua (HL\&T 2008: 5): Accent $1 \rightarrow$ Accent 2 in plural (condition: if stem has three or fewer syllables) 


\subsubsection{Beheranzko azentua duten hitzen azentuera galderetan}

Galderetan doinuak ñabardura asko gehitzen ditu. Hemen galdera neutroetan erabiltzen den azentuak beheranzko azentua duten hitzengan sortzen duten eragina azaltzera mugatuko gara.

Galdegaia galderaren 1. elementu gisa agertzen denetan, galderak berez du doinu bat eta goitik beherakoa da.

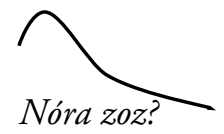

Beheranzko azentua duten hitzekin mota honetako galderak egiten ditugunean, silaba azentudunek goranzko azentua hartzen dute, galderetako 1. elementu gisa agertzen badira.

- Klase III [+2, b]: eskòla, basèrri, alàbak (pl.)

—Klase IV [+1, b]: bàso ('edalontzi'), àrima, kàfe, fábrika, àmak (pl.), lèngusu

- Klase IIIko hitzekin galderak: Eskólara al dio? Basérrira al dio? Basérrikoa al da?

— Klase I ko hitzekin galderak: Básoa nahi al tzo? Arimik ba al do horrek? Káfeik na al tzo? Léngusua al da?

Klase II/ko adibideak beheranzko azentuarekin esatea ere posible da: Eskòlara al dio? Azentua 2. silaban izatean, galderaren azentu arau hori hain hertsiki bete behar ez izatearen ondorio izan daiteke gertaera hori.

Adibideetan ez ditugu sartu pluralezko formak. Izan ere, ez zaigu erraz egiten pluralarekin zer gertatzen den jakitea. Hala ere, gure ustez gertatzen dena azalduko dugu: galderetan singularra eta plurala bereizteko moduan ahoska daitezke edo berdin ahoska daitezke. "Bereizteko moduan» esatean, esan nahi duguna da pluralaren beheranzko doinua igotzen dela, baina ez singularra igotzen den adina. Oso diferentzia ttikia bada ere, singularrak goragoko doinua hartzen du. Hala ere, goranzko azentuarekin adieraziko genuke plurala ere, ez beheranzkoarekin: Ámak al dia horiek? Ámak kusi al do? Alábak torri al zkio? Alábak san al dio?

\subsubsection{HéL 2008ko adibideak osatuz}

Artikulu honetan, oinarri hirusilabadunetako euskal jatorriko hitzen artean, Klase I ho adibide gutxi eman genituen (H\&L 2008: 346):

(5) Euskal jatorrizko hirusilabadunak

Klase I: alába, anái(a), amóna, arréba, izéba, itsáso, itsúsi, ipúrdi, izérdi, arnása, astíar ('astigar'), ittúrri, arrántza (astoarena), beláso (< belar + soro), asérre, abé(ra)ts (< Lat. habere + -ats), neskáme, ostégun, ostíel ('ostiral'), txingúrri, giltxúrdin

Klase II: hálako, nóloko

Klase III: arràno, arràntza (arrantzaleena), arràutza ('arraultze'), intxàur, basèrri, bazkàri, belàrri, burrùntzi, motiko, ollàsko, illàrgi

Klase IV: lèngusu 
Klase IVko zerrenda osatzeko, adibide batzuk ekarri ditugu, aditzak gehienak: bàzkari zhr (bazkàri gzt), bàzkaldu zhr (bazkàldu gzt), àurretu, àtzetu, zipatu / zìputu.

Klase IIrako hauek topatu ditugu: góttiko, béttiko, úmetu.

3. silaban azentuatzen den klaserik ez genuen eman, adibiderik topatu ez genuelako. Orain ere berdin segitzen dugu, eredu hori posible dela iradokitzen diguten hitz hauek bildu arren: astelén, ùrrengó, battùzté, lur onékin (azken adibide honen antzekoak asko daude, beste silababakarrekin osatutakoak batetik, eta bestetik, soziatiboaren ordez beste deklinabide atzizkiak erabiliz).

Oinarri lausilabadunetan, euskal jatorriko nahiz maileguetako Klase II eta $I V$ adibiderik gabe gelditu zitzaizkigun (H\&L 2008: 347):

(7) Euskal jatorriko lausilabadunak

Klase Ia: barátzuri ('baratxuri'), basérritar ${ }^{17}$, bertsólari, emákume, nekázari, txistúlari,

Klase II: --

Klase III: Elìzondo

Klase IV: --

(8) Mailegu lausilabadunak (eta luzeagoak)

Klase Ia:

Zaharrak: alkándora, errégina, anímali

Berriak: entsálada, Cocá-Cola, soziálismo, kapítalista, kalímotxo, demónio, inóxente, abrélatas

Klase II: --

Klase III: apòstolu

Klase IV: --

Klase II osatzeko, honako hitz zerrenda ekarri dugu, gehienak hitz elkartu edo eratorri izan arren, hitz eredu hau badagoela adierazteko: yéndetasuna zhr, tzútendemon $\mathrm{zhr}$ (<duzuten denboran), zérrengatik, yásotzeko, kónturatu.

Klase IV osatzeko ez dugu lau silabatako hitzik aurkitu, baina lau silaba eta aurrena beheranzko azentuarekin esatea posible dela ikusteko, hara adibide batzuk: $m \dot{o}-$ tongatik, kòtxetako, lèngusukin... Alegia, 1. silaba beheranzkoa duen hitzari deklinabide atzizkiak gehituta horrelako azentu eredua entzun dezakegu, baina ez dira lau silabatako hitzak bere horretan.

\subsection{Egiteke dagoena}

Goizuetako azentu arauei buruzko atal honetan arau batzuen berri eman dugu. Sistemaren konplexutasuna arauetara ekarriz sinpletu nahi izan dugu, baina aldiro galdetu diogu gure buruari arauek sistemaren izaera ongi ordezkatzen ote zuten. Segur aski, gauza askok ihes egin digute. Konturatu garenen artean, egiteke daudenak hemen azaltzen ditugu.

17 Baita basèrritar ere. 
Aldakortasunean dauden hitzen zerrenda osatu eta aldakortasunaren zergatia ikertzea (zein da berriagoa? Zeinetan gertatzen da aldaketa?). Aldakortasuna, bi modutan ulertuta:

- Ondoren - a edo izan aditza jarrita goranzko azentua hartzen duten hitzak.

- Testuinguru berean, hiztunaren arabera modu batera edo bestera esan daitezkeen hitzak (Berá / Bèra, bàzkari / bazkàri, bàzkaldu / bazkàldu, létxua / letxùa, zintzatu / zintzàtu, púre / purè...).

Azentu patroiak. Azentu eredu batzuk zerrendatu ditugu (H\&L 2008), baina hauek dira denak? Besterik egon daiteke, 3. silaban azentuatutakoak adibidez, asteléna hitzak erakusten digun bezala (astélena ere esaten da). 3. silaban azentua duen beste hitzik ez dugu topatu, ordea (ikus 4.2.8.). Oraingoz, ezin jakin horrelako azentu patroirik baden.

Egindako grabazioetan lantzeko material ugari dago. Elkarrizketa guztietan azentuak markatu beharko lirateke eta sakonago aztertu.

Ekarpen berrien atalean, hainbat hizkuntza elementuren azentu arauez informazioa bildu eta aztertu dugu: silababakar, aditz jokatu, adberbio, juntagailu, pertsona eta herri izenen azentuera... Informazioa zabaltzearekin batera, arau batzuk argitu ditugu eta baita, galdera berriak ireki ere.

Bukatzeko, argitu gabe gelditzen da zergatik «Plural accent rule» ez den aplikatzen erroa hiru silaba baino gehiagokoa duten hitzetan (HL\&T 2008: 5. orriko 6. oharrean gauza bera esaten $\mathrm{da}$ ):

The domain of stress assignment is the stem. This can be concluded from the fact that all words with monosyllabic stems have initial prominence. An interesting question, which we leave for future research, is why the Plural Accent Rule does not apply to words whose stem has more than three syllables. We note that in some Gipuzkoan Basque dialects a singular/plural accentual contrast obtains in an even more restricted manner: only in words with mono- or bisyllabic stems. (Etzana nirea da)

\section{Goizuetako azentuaren ezaugarri fisikoak}

\subsection{Orain arte esan dena}

Zuzenean Goizuetako azentueraz hitz egin duten lanak gutxi direla esan dugu. Goizuetako azentuaren ezaugarri fisikoei buruzkoak ez dira gehiegi eta hona bildu ditugu, puntu garrantzitsuenak laburtuz:

Zubiri, J.J. 2000. «Arano eta Goizuetako hizkera» in Zuazo, K. (arg.) Dialektologia gaiak. Gasteiz: Arabako Foru Aldundia.

Hualde, J.J. 2007. «Historical convergence and divergence in Basque accentuation». In: Tomas Riad eta Carlos Gussenhoven (arg.). Tones and tunes: Typological studies in word and sentence prosody. Berlin: Mouton de Gruyter.

Hualde, J.I., Lujanbio O. eta Torreira, F. 2008. "Lexical tone and stress in Goizueta Basque». Journal of the International Phonetic Association 38 (1): 1-24. 


\subsubsection{Zubiriren (2000) deskribapena}

Zubiriren artikuluan, Goizuetako azentuaren inguruan esandakoak biltzen direla esan dugu. 4.1.1. atalean, Goizuetako azentu arauei buruz beste adituek esandakoak eta Zubirik bildutakoak azaldu ditugu, eta hemen Goizuetako azentuaren ezaugarri fisikoekin gauza bera eginen dugu. Beste adituek esandakoarekin hasiz, honakoa da hortik atera dugun ezaugarria:

Bokal azentudunak intentsitate gehiago eta iraupen luzeagoa du. Fenomeno honen ondorio bezala azaltzen ditu Mitxelenak inguru honetan ohikoak diren hots galerak eta sinkopak (batetik, Irun, Hondarrabia eta Bortzerrietaz ari da Mitxelena, eta Basaburua Ttikiaz eta Ultzamaz, bestetik, 1977: 389-391). ${ }^{18}$ Antzeko baieztapenak egiten $\operatorname{ditu} A$ note on Old labourdin accentuation artikuluan ere, 4. azentu tipoaz ari denean (1972: 115).

Goizuetako azentuaren ezaugarri fisikoei buruz Zubirik berak esandakoak hauek dira:

Musikalitatea. "Gaminderen hipotesiaren alde egoteko beste zio garrantzitsua herri bateko eta besteko hizkerek duten tonu, doinu, melodia edo musikalitatea dateke: goizuetarrok hitz egitekoan kantatu egiten omen dugu (bai gipuzkoarrentzat eta baita aranoarrentzat ere), baina goizuetarrontzat kantatzen dutenak Malerreka eta Bortzerrietakoak dira» (Zubiri 2000: 93-94, Goizueta eta Aranoko hizkeren azentuera diferentea dela adierazteko azalpena).

Azentu bigarrenkaria. Bi azentu mota dituela Goizuetako hizkerak dio Zubirik; «izen guztiek azkeneko silaban azentu bigarrenkaria hartzen dutela, batez ere mugatzaileren bat edo deklinabide atzizkiren bat eransten zaienean (cf. gizónakin, bildótsarì, belárritik...)» (Zubiri 2000: 97).

Bokal luzeak. Zubiriren arabera, azentu bigarrenkari hau, desberdina da izen motaren arabera: batetik, bukaera kontsonantedunak eta bukaera bokaldunak (baina azentua azken silaban ez dutenak bakarrik) multzokatzen ditu (gizón, itsáso) eta, bestetik, bokalez bukatu eta azentu nagusia bokal horretan daramatenak (asté). Izen mota hauetan, bokal luzeak agertzen direla esaten du. 1. multzoko izenetan, pluraleko forma luzatzen da (gizó:nak) eta 2. multzokoetan, singularreko forma (asté:k) (Zubiri 2000: 97).

Mugagabea eta mugatua bereizteko ere (2. multzoko izenetan), bokal luzeak baliagarri direla dio Zubirik.

18 Ildo beretik doa H\&L (2008: 342)ko aipua ere: Mitxelena (1972) ohartu zen bezala, Nafarroako eskualde honetan, Bizkai-Gipuzkoetako hizkeretan ez bezala, silaba azentudun eta azentugabeen arteko diferentzia fonetikoak handiak dira. Silaba azentuduna besteak baino askoz luzeagoa eta intentsoagoa da. Silaba azentugabea askotan oso laburrak da. Diakronian, horren eragina silaba azentugabeen galeran ikusten da: txokòlte (< txokolate), pàtu $(<$ paratu), zértik $(<$ zergatik), etab. 


\subsubsection{Hualderen (2007) deskribapena}

Hualderen artikulu honen arabera, Goizuetako azentuerak bi ezaugarri ditu:

Singularraren eta pluralaren arteko doinu diferentzia. Hitza singularrean edo pluralean esan, doinu diferentea du: singularrean, azentuatutako silabaren ondoren tonu beherakada heldu da. Pluralean berriz, beherakada ez da hain nabaria, hitzaren azken silaban tonu gorakada dagoelako. Hau azaltzeko honakoa dio (Hualde 2007: 14):

A possible analysis of these facts would be to postulate that the accent of the stem is circumflex $\left(\mathrm{H}^{*} \mathrm{~L}\right)$ in the singular and acute $\left(\mathrm{H}^{*}\right)$ in the plural, which has another accent on the suffix.

Hitza esaldi bukaeran egotean, singularrak eta pluralak duten doinu diferentzia. Hitza esaldiaren bukaeran baldin badago, azken silabak bigarren tontor bat du, lehena baino ttikiagoa. Pluralean, berriz, tontor nagusia azken silabakoa dela dio. Hitzaren eta atzizkiaren azentua silaba berean baldin badago, aldiz (mendi-ak $>$ mendik), silaba honek singularrean, gailurraren ondoren, beherakada erakusten du eta pluralak ez. Ondorio nagusia hau da: singularrean tontor bat eta azentu bat dago $\left(\mathrm{H}^{*} \mathrm{~L}\right)$ eta pluralean bi tontor eta bi azentu $\left(\mathrm{H}^{*} \mathrm{H}^{*}\right)$ (Hualde 2007: 15).

Artikulu honen ondoren egindako azterketek fenomeno hau hobeki ulertu eta modu sakonagoan ikusten lagundu digute, jarraian azaltzen den artikuluan bertan agertzen den bezala.

\subsubsection{Hualde, Lujanbio eta Torreira (2008)}

Artikulu hau da Goizuetako azentuaren ezaugarri fisikoak gehien landu dituena. Hizkera honen azentuaren intentsitatea, doinua eta iraupena aztertzen dira bertan.

Egile hauen arabera, Goizuetako azentuak bi bereizgarri ditu, gainerako azentueretatik ezberdin egiten duena. Batetik, bi azentu mota ditu: Azentu 1 (akutua edo goranzkoa) eta Azentu 2 (grabea edo beheranzkoa). Azentu 1 markatugabea da eta 'ikurrarekin adierazten da eta Azentu 2 markatua da eta ' azentuarekin adierazten da. Eta bestetik, intentsitateak eta iraupenak sortzen duten bereizkuntza ere badago: 1. edo 2. silaba izan daitezke indar gehien duten silabak eta beraz, bi hauetako batean azentua daitezke hizkera honetako hitzak.

Azentu mota bat edo bestea agertzea, hitzaren arabera eta morfologiaren arabera izaten da. Beraz, azentuak bereizkuntza lexikoa eta morfologikoa egiten du. Hau da, bereizkuntza lexikoari dagokionez, hitz batzuek berez dute goranzko (alába) edo beheranzko (belàrria) azentua. Bereizkuntza morfologikoari dagokionez, adibide hau emango dugu: hiru silaba edo gutxiagoko erroa duten hitz batzuetan, singularrak eta mugagabeak goranzko azentua izan arren, pluralak beheranzkoa hartzen du (alàbak).

Hitzak 1. edo 2. silaban azentuatu ahal izateaz gain, bi silaba hauetan bi azentu motak ager daitezke: átta, màillu, alába, belàrri.

Intentsitatea eta azentu mota ikertzeko egindako grabaketa batzuk aztertu eta hauetatik ateratako ondorioak azaltzen dira artikulu honetan. Grabaketak Goizuetako hiru hiztun gazteri egindakoak dira eta hirurek ahoskatutako esaldien arteko intentsitate, iraupen eta doinu diferentzia eta antzekotasunak neurtu ziren. Ondorio nagusietako bat, beheranzko azentua duten hitzek bukaeran duten gorakada (hitza 
esaldi bukaeran dagoenean, aipamen forma ${ }^{19}$ barne) esaldi mailako prosodiak eragindakoa dela da, eta ez hitzak berez duena. Suedieran bezala, gorakada hau galdegaiarekin lotua dago (HL\&T 2008:15). Beste ondorio bat, azentu mota baten eta bestearen arteko aldea, azentua daraman silabaren doinu diferenteek sortua dela da (HL\&T 2008: 20).

Beraz, Hualderen 2007ko artikulutik honetara Goizuetako azentuera ulertzeko modua aldatu egin dela esan dezakegu. Aldaketa nagusia honetan datza: orain goranzko eta beheranzko azentuak daudela esanez esplikatzen dira singular eta pluralaren arteko aldeak.

\subsection{Egiteke dagoena}

Lan honetan ez dugu Goizuetako azentuaren ezaugarri fisikoez azterketarik egin. Beraz, egiteke daudenak zerrendatzera mugatu gara atal honetan.

Singularraren eta pluralaren arteko bereizketa Klase III eta IV-ko hitzetan: bi artikulutan aipatu izan da gaia:

— Hualde eta Lujanbio (2008: 343). Mugagabean eta singularrean hitzak beheranzko azentua badu (Klase III eta $I V$ ), singularra eta plurala azentuaz desberdintzen dira? Hipotesi bat da hiztun batzuek pluralean doinu baxuagoa ematen diotela silaba azentudunari. Hiztun batzuek diogu, beste batzuek ez dutelako diferentzia hori egiten (lan hau idazten ari dena, adibidez). Azken hauen arabera, honako adibide hauek ditugu:

belàrria $(\mathrm{sg}) /$ belàrrik $(\mathrm{pl})$

belàrriri $(\mathrm{sg}) /$ belàrriri $(\mathrm{pl})$

bàsokin $(\mathrm{sg}) /$ bàsokin $(\mathrm{pl})$

— Hualde, Lujanbio eta Torreira (2008: 5): Hemen ere ohar bera egiten da:

Some speakers may be able to express the singular/plural contrast in words of classes $\mathrm{C}$ and $\mathrm{D}^{20}$ by a greater lowering of the pitch in the plural, even though in both numbers there is a falling tonal contour over the stressed syllable. Establishing this requires further investigation.

Hau gazteek galdu duten bereizkuntza bat den argitzeke gelditzen da.

Esaldi mailako azentu prosodikoa: Goizuetako hizkeraren esaldi mailako prosodia edo intonazioa aztertu gabe dago. Hurrengo atalean hitz multzo batzuek hartzen duten azentuerari buruzko zertzelada batzuk eman dira, baina askotan zail egiten da bereiztea azentu bat esaldi mailako prosodiaren eraginezkoa den edo hitzarena den, berez. Konparaziora, ondorengo adibidean, letra lodiz markatutako hitzen azentua intonazioarena dela uste dugu. Esaldi bukaerako gorakada intonazioarena dela adierazteko, bi kakotx erabili ditugu, bata bestearen jarraian (,,). 80 urteko Goizuetako emakume baten adibidea da hau.

19 Originalean citation form-etik itzulia.

20 H\&Lko terminologian Klase III eta $I V$. 
Oan ya horì áttutzen ài dá,,. Bèste hizkùntza. Guk ìtten dú zèta. Ta haiek berríz, ba, esé,,.

\section{Azentua hitz taldeetan}

Orain arte, hitzak isolaturik esatean duten azentuerari buruz hitz egin dugu, nagusiki. Atal honetan, hitz taldeetan izenek dituzten aldaketei buruz hitz egingo dugu. Izen eta adjektiboen eta izen eta erakusleen arteko multzoen gainean arituko gara aurrena, aditz nagusi eta laguntzailearen artekoaz ondoren eta hitz elkartuez azkenik.

\subsection{Izen + adjektibo}

Hitz talde honetan, izenaren ezaugarrien arabera jokaera ezberdinak daude. Batetik, izenaren silaba kopuruak eragina du eta, bestetik, izenaren azentu klaseak. Adjektiboaren azentuak hitz motzetan du eragina. Azentuera ezberdineko adjektiboak paratu ditugu kasu guztietan, konbinazio desberdinak erakusteko. Aurrez barkamenak talde semantiko "xelebreengatik». Oinarri bisilabadunekin hasiko gara (adibideak H\&L 2008tik hartu dira):

\subsubsection{Oinarri bisilabadunak}

\begin{tabular}{|c|c|}
\hline Klase I $[+2, \mathrm{~g}]$ : gizón & $\begin{array}{l}\text { Izenak goranzko azentua galtzen du ondorengo adjektiboak goranzko } \\
\text { azentua badu eta goranzkoa mantentzen du ondorengo adjektiboak } \\
\text { beheranzkoa badu: gizon ttíkia, gizon aundía, gizón pikaróa, gizón } \\
\text { euskálduná. }\end{array}$ \\
\hline Klase II $[+1, \mathrm{~g}]: a ́ m a$ & $\begin{array}{l}\text { Azentua bere horretan mantentzen du; } 1 \text {. silaban eta goranzkoa: áma } \\
\text { ttíkia, áma aundía, áma pikaróa, áma euskàlduná. }\end{array}$ \\
\hline \multicolumn{2}{|l|}{ Klase III $[+2, b]:--$} \\
\hline Klase IV $[+1, \mathrm{~b}]:$ màlko & $\begin{array}{l}\text { Azentua bere horretan mantentzen du; } 1 \text {. silaban eta beheranzkoa: } \\
\text { màlko ttíkia, màlko aundía, màlko pikaróa, màlko euskàlduná. }\end{array}$ \\
\hline
\end{tabular}

\subsubsection{Oinarri hirusilabadunak}

\begin{tabular}{|l|l|}
\hline Klase I $[+2, \mathrm{~g}]$ : alába & $\begin{array}{l}\text { Azentua bere horretan mantentzen du; 2. silaban eta goranzkoa: alába } \\
\text { ttíkia, alába aundía, alába pikaróa, alába euskàlduná. }\end{array}$ \\
\hline Klase II $[+1, \mathrm{~g}]$ : álako & $\begin{array}{l}\text { Azentua bere horretan mantentzen du; 1. silaban eta goranzkoa: álako } \\
\text { ttíkia, álako aundía, álako pikaróa, álako euskàlduná. }\end{array}$ \\
\hline Klase III $[+2, \mathrm{~b}]$ : arràno & $\begin{array}{l}\text { Azentua bere horretan mantentzen du; } 2 . \text { silaban eta beheranzkoa: } \\
\text { arràno ttíkia, arràno aundía, arràno pikaróa, arràno euskàlduná. }\end{array}$ \\
\hline Klase IV $[+1, \mathrm{~b}]$ : lèngusu & $\begin{array}{l}\text { Azentua bere horretan mantentzen du; } 1 \text {. silaban eta beheranzkoa: lèn- } \\
\text { gusu ttíkia, lèngusu aundía, lèngusu pikaróa, lèngusu euskàlduná. }\end{array}$ \\
\hline
\end{tabular}




\subsubsection{Oinarri lausilabadunak}

\begin{tabular}{|l|l|}
\hline Klase Ia $[+2, \mathrm{~g}]:$ barátzuri & $\begin{array}{l}\text { Azentua bere horretan mantentzen du; 2. silaban eta goranzkoa: bará- } \\
\text { tzuri ttikia, barátzuri aundia, barátzuri pikaróa, barátzuri euskàlduná. }\end{array}$ \\
\hline Klase II $[+1, \mathrm{~g}]:--$ & \\
\hline Klase III $[+2, \mathrm{~b}]:$ Elizondo & $\begin{array}{l}\text { Azentua bere horretan mantentzen du; 2. silaban eta beheranzkoa: Eli- } \\
\text { zondo ttikia, Elizondo aundía, Elizondo pikaróa, Elizondo euskàlduná. }\end{array}$ \\
\hline Klase IV $[+1, \mathrm{~b}]:--$ & \\
\hline
\end{tabular}

Hemen zerrendatutakoa ikusita, ondorio hauek atera ditugu:

- Adjektiboaren azentuzko ezaugarriek ez dute eraginik bi silabatik gorako izenetan, orohar. Salbuespen batekin: oinarri hirusilabadunetako Klase IIIn izenak goranzko azentua ere har dezake adjektiboak beheranzko azentua badu: arráno pikaroa, arráno euskàlduná.

- Oinarri bisilabadunetan, Klase Ieko izenetan bakarrik eragiten dute adjektiboaren azentu ezaugarriek, modu honetan: izenari goranzko azentua kentzen zaio adjektiboak goranzko azentua badu eta goranzkoa mantentzen du, adjektiboak beheranzkoa badu: gizon ttíkia, gizon aundía, gizón pikaróa, gizón euskàlduná (H\&L 2008: 348, silababakarretan 9b-ko adibideei buruz esaten denaren antzekoa gertatzen da). Gizon pikaróa, gizon euskàlduná bezalako adibideak ere badaude.

— Oinarri bisilabadunetako Klase IVn ere aldakortasuna nabaritu dugu: malko pikaróa, malko euskàlduna adibideez gain, málko pikaróa eta málko euskàlduná bezalako azentua dutenak entzun daitezke (berriz barkamena adibideengatik...) edo baita, beheranzko azentua mantendu duten adibideak ere: mälko pikaróa eta màlko euskàlduná.

\subsubsection{Silababakarrak}

Bi silaba edo gutxiago dituzten izenetan gauza konplikatu egiten da. Dagoeneko esana dugu silababakarren azentua aldakorra dela ondoren jartzen zaionaren arabera. Hemen hori berretsi egiten dugu. Azentu aldakorra izan arren, hiztegian hitzak zerrendatzeko erabilitako irizpidearen arabera (ondoren - $a$ edo izan aditza jartzea), silababakar batzuek goranzko azentua dute eta beheranzkoa beste batzuek.

— Beheranzko azentua dutenak: mài ('mahai'), nài ('nahi').

— Goranzko azentua dutenak: bóz ('ahots'), lúr ('lur'), mé ('mehe'), pútz ('putz').

Hauen kasuan ere, ondoren goranzko azentua edo beheranzko adjektiboa duena jartzea ez da berdin. Horrelako adibideak dira posible, konbinazio bakoitzean:

\begin{tabular}{|l|l|}
\hline 'azentua duen silababakarra + adj. & 'azentua duen silababakarra + adj. \\
\hline $\begin{array}{l}\text { mài aundía, mài ttíkia } \\
\text { mai aundía, mai ttíkia }\end{array}$ & $\begin{array}{l}\text { pùtz aundía, pùtz ttíkia } \\
\text { putz aundía, putz ttíkia }\end{array}$ \\
\hline $\begin{array}{l}\text { mái pìkaróa, mái euskàlduná } \\
\text { mai pìkaróa, mai euskàlduná }\end{array}$ & $\begin{array}{l}\text { pútz pìkaróa, pútz euskàlduná } \\
\text { putz pìkaróa, putz euskàlduná }\end{array}$ \\
\hline
\end{tabular}


Bat edo beste zeren arabera erabiltzen den ezin esan. Baina argi dagoena hau da:

- Silababakarrak goranzko azentua edo beheranzkoa izan, ondoren adjektiboa jarrita jokaera berbera du.

— Konbinazio batzuk posible dira eta beste batzuk ez. Adibidez, hau ezinezkoa da: silababakarra + ' azentua duen adj. > ' azentua duen silababakarra (mái aundia, pútz ttikia).

- Silababakarra + 'azentua duen adj. > ' azentua duen silababakarra konbinazioa ez dela posible ere esan daiteke, baina horretarako, beheranzko azentua eta azenturik ez edukitzea zer diren ongi bereizi behar dira, bien arteko muga belarri hutsez ezartzea zaila baita (Praat programaren bidez baten eta bestearen arteko alderaketak eginez, adibidez).

Hemen zerrendatutakoa kontuan hartuta, ondorio gisa hau esan dezakegu:

- Goranzko azentua duten adjektiboekin (aundi, ttiki) silababakar guztiek beheranzko azentua hartzen dute edo azenturik gabe gelditzen dira.

- Beheranzko azentua duten adjektiboekin (pikaró, euskàldun), silababakar guztiek goranzko azentua hartzen dute edo azenturik gabe gelditzen dira.

- Jatorrian goranzko edo beheranzko azentua izan, jokaera berbera dute.

Atal honetan xehe deskribatutakoa orokortzen saiatuta, badirudi ezin dutela bi goranzko azentuk elkarren jarraian egon, tartean bi silabako tartea ez badago, bederen. Beraz, adjektiboak goranzko azentua badu, aurreko bi silabetan beheranzko azentua egongo da. Adjektiboaren, 2. elementuaren azentuak agintzen du. Horrela azaltzen ahal ditugu oinarri silababakar eta bisilabadunetan gertatzen diren aldaketak:

pútz + ttiki > putz ttiki edo pùtz ttíki

gizón + ttiki > gizon ttiki edo gizòn ttiki

Ez ahaztu izen + adjektibo elkarketaz ari garela orokortasun hau egitean. Arau hau testuinguru guztietan ez da betetzen, 80 urteko emakume batek esaldi honetan erakusten duenez: Tolósan bezàlatsú itten da Donóstin $e$.

\subsection{Izen + erakusle}

Hitz talde honetan ere, izenaren ezaugarrien arabera jokaera ezberdinak daude. Izen + adjektibo taldean gertatzen den bezala, batetik, izenaren silaba kopuruak eragina du eta, bestetik, izenaren azentu klaseak. Erakusleen ezaugarriek hitz motzetan dute eragina. Oraingoan, ditugun erakusleetara mugatuko dira konbinazio posibleak eta silababakarren analisia batera egin dugu. Hurrengo taulan oinarriaren silaba kopuruaren arabera banatu ditugu hitzak.

\begin{tabular}{|l|l|l|l|}
\hline \multicolumn{1}{|c|}{ Silaba 1 } & \multicolumn{1}{|c|}{ 2 silaba } & \multicolumn{1}{c|}{ 3 silaba } & \multicolumn{1}{c|}{ 4 silaba } \\
\hline mài & gizón & alába & barátzuri \\
bóz & áma & álako & - \\
& $\begin{array}{l}\text { arràno } \\
\text { màlko }\end{array}$ & lèngusu & - \\
& &
\end{tabular}


Erakusleak hauek dira:

\begin{tabular}{|l|l|}
\hline Singularra & \multicolumn{1}{|c|}{ Plurala } \\
\hline $\mathrm{au}$ & òik \\
\hline orí & orìk \\
\hline orá & àik \\
\hline
\end{tabular}

Bat eta bàtzuk zenbatzaileak ere aztertu ditugu.

Erakusleak izenarengan duen eragina ikusteko, izen + erakusle elkarketara mugatzeak fenomeno osoa ez duela biltzen konturatu gara (ori eta orá erakusleen kasuan dago aldea). Horregatik izen + erakusle + izan aditza ere elkarketa ere aztertu dugu. Honako bilakaerak agertu zaizkigu (hemen ere oso adibide artifizialak sortu dira, laborategikoak):

\begin{tabular}{|c|c|c|}
\hline & IZ + ERAK & IZ + ERAK + IZAN \\
\hline bat & $\begin{array}{l}= \\
\text { Izen guztiek beren azentua mantentzen dute } \\
\text { mài bat }(d a), \text { bóz bat }(d a)\end{array}$ & \\
\hline $\mathrm{au}$ & $\begin{array}{l}= \\
\text { Izen guztiek beren azentua mantentzen dute } \\
\text { mài au }(d a), \text { bóz } a u(d a)\end{array}$ & \\
\hline orí & $\begin{array}{l}= \\
\text { Izen guztiek beren azentua mantentzen dute } \\
\text { mài orí, bóz ori }\end{array}$ & $\begin{array}{l}\text { mài orí } \mathrm{da}= \\
\text { bóz }+ \text { orí }>\text { bòz orí da } \neq \\
\text { gizón }+ \text { orí }+ \text { izan }>\text { gizòn orí da } \\
\text { Gainerakoek }=\end{array}$ \\
\hline orá & $\begin{array}{l}= \\
\text { Izen guztiek beren azentua mantentzen dute }\end{array}$ & $\begin{array}{l}\text { mài orá } \mathrm{da}= \\
\text { bóz }+ \text { orá }>\text { bòz orá da } \neq \\
\text { gizón }+ \text { orá }+ \text { izan }>\text { gizòn orá da } \\
\text { Gainerakoek }=\end{array}$ \\
\hline bàtzuk & \multicolumn{2}{|c|}{$\begin{array}{l}\neq \\
\text { beheranzko azentua duten silababakarrek > goranzkoa } \\
+ \text { beheranzko azentua duten bisilabadunek > goranzkoa batzuetan } \\
\text { mài + bàtzuk > mái bàtzuk (día) } \\
\text { màlko + bàtzuk > málko bàtzuk (día) (màlko bàtzuk ere posible da) }\end{array}$} \\
\hline òik & \multicolumn{2}{|c|}{$\begin{array}{l}\neq \\
\text { beheranzko azentua duten silababakarrek > goranzkoa } \\
+ \text { beheranzko azentua duten bisilabadunek > goranzkoa batzuetan } \\
\text { mài + òik > mái òik (diá) } \\
\text { màlko + òik > málko òik (diá) (màlko oik ere posible da) }\end{array}$} \\
\hline orìk & \multicolumn{2}{|c|}{$\begin{array}{l}\neq \\
\text { beheranzko azentua duten silababakarrek > goranzkoa batzuetan } \\
+ \text { beheranzko azentua duten bisilabadunek > goranzkoa batzuetan } \\
\text { mài + orìk > mái orik (diá) } \\
\text { màlko + orì > málko orik (diá) (màlko orik ere posible da) }\end{array}$} \\
\hline
\end{tabular}




\begin{tabular}{|l|l|l|}
\hline & \multicolumn{1}{|c|}{ IZ + ERAK } & \multicolumn{1}{|c|}{ IZ + ERAK + IZAN } \\
\hline àik & $\begin{array}{l}\text { f } \\
\text { beheranzko azentua duten silababakarrek > goranzkoa } \\
+ \text { beheranzko azentua duten bisilabadunek > goranzkoa batzuetan } \\
\text { mài + àik > mái àik (diá) } \\
\text { màlko + àik > málko àik (diá) (màlko àik ere posible da) }\end{array}$ \\
\hline
\end{tabular}

Taulari buruzko oharrak:

- Aldaketak letra lodia eta $\neq$ ikurra erabiliz adierazi ditugu.

- Sortzen diren adibideak ez luzatzeagatik, azentu gabeko adibideak ez ditugu eman. Baina kontuan hartu beheranzko azentua duten adibideen ondoan azentu gabekoak ere posible direla.

Honako ondorioak atera ditugu:

— iz. + adj.entzat atera dugun arau orokorra hemen ere aplikagarria da. Hau da, bi goranzko azentuk ezin dute elkarrengandik bi silabako tartea baino gertuago egon (ikus orí eta orá erakusleak taulan).

- Gauza bera gertatzen da bi beheranzko azentu elkarren ondoan daudenean: Bi beheranzko azentuk ezin dute elkarrengandik bi silabatako tartea baino gertuago egon (ikus bàtzuk, òik, orík eta àik).

— Hemen ere, adibide guzti hauetan, 2. elementuak agintzen du.

\subsection{Aditz + laguntzaile}

Dagoeneko hitz egin dugu aditzen azentuerari buruz 4.2.2. puntuan. Aditz laguntzailearekin zerikusia duen ondorio hau ekarri dugu handik hona:

Hiru multzo hauek identifikatu eta gaia sakonago aztertzean, ohar hauek egin ditzakegu:

- (1) eta (3) multzoko aditz-izenak beheranzko azentuarekin paratu ditugu (àintzen, airàtzen) baina, galdegai-gunean egon edo ez, azentuera aldatzen duela ohartu gara:

a. Beheranzko azentuarekin, galdegai denean agertzen da: àintzen dút / beti àintzen ái za; airàtzen da / abiona airàtzen ái da.

b. Goranzko azentuarekin, esaldi markatugabe batean: hemen nik äintzen dut; txoría àixa airátzen da.

-(3) multzoko partizipioarekin ere gauza bera gertatzen da (airàtu):

a. Beheranzko azentuarekin, galdegai denean agertzen da: txoría airàtu (in) da.

b. Goranzko azentuarekin, esaldi markatugabe batean: txoría airátu da.

- Aditz-oinarekin gertatzen dena argitu gabe gelditzen zaigu: hiztegian markatu bezala iruditzen zaizkigu arruntenak, baina testuinguruaren arabera aldatzen direla badakigu.

- (2) multzoko aditzek ez dute beheranzko azentua hartzen. 
Hona aipatzen den multzoetako adibide bana:

(1) Azentu aldakorra duten aditzak: *áindu, àin, àintzen / áinddu (agindu)

(2) Goranzko azentua duten aditzak: abixtu, abix, abixten (abisatu)

(3) Beheranzko azentua duten aditzak: airàtu, airà, airàtzen (airatu)

Kontua da, aditz laguntzaileaz baino, aditz nagusia galdegai izan edo ez izatearen arabera aditz nagusiak duen azentueraz ari garela. Pare minimo hauek ditugu esandakoaren erakusle:

(1) eta (3) multzoko aditzen jokaera: aditza ez bada galdegaia, goranzko azentua $\mathrm{du}$, galdegaia bada, beheranzkoa

Yéndek aintzen al do? Ez, diruk áintzen do.

Diruk ezto déustako balio! Ez, dirruk àintzen do.

Eulía airátu al da? Ez, txoría airátu da.

Txoría hemen al da? Ez, txoría airàtu da.

(2) multzoko aditzen jokaera: aditzak beti goranzko azentua du

Launak abixtu al dizute? Ez, bizilaunak abixtu diate.

Yon al tza plazara? Ez, bizilaunak abixtu diate (ez yoteko).

Gure hipotesia, hain zuzen ere, hori da: galdegai izan edo ez aldatzen dela azentuera eta ez ondoren heldu den aditz laguntzailearen arabera. Gainera, aditz laguntzaile hori esaldi bukaerako intonazioaren indarpean egoten da eta, askotan, ez da erraz bereiztea aditz laguntzailearen beraren azentua den edo esaldi mailako prosodiarena. Batzuetan, azentu gabea dirudi eta doinu eta indar diferenteak esaldi mailako prosodiak ematen dizkiola uste dugu. Gainerakoan, 4.2.2. puntuan adierazi bezala ahoskatzen dira aditzak, orokorrean.

Lan honen helburua Goizuetako azentuera aztertzeko hiztegia osatu eta hitz solteen azentua aztertzea izan da. Hortik izen + adjektibo eta izen + erakusle hitz multzoak aztertzera animatu gara. Aditz + laguntzaile hitz taldeetan faktore gehiago nahasten dira (aditz eta aditz laguntzailearen ezaugarriez gain, esaldi mailako prosodiarena) eta hor gertatzen dena jakiteko, azterketa sakonago bat behar da.

\subsection{Hitz elkartuak}

Hitz elkartuen azentuerari buruzko hipotesiak egiteko, Zubirik plazaratutako aldaketetatik abiatuko gara. Zubirik, hitzak bereiz esan edo hitz elkartu gisa esan, diferente azentuatzen direla dio (Zubiri 2000: 96):

lán berría $\neq$ lanbérria

púska leór $\neq$ puskáleor

góiz aldéra $\neq$ goizálderà

órtz aundía $\neq$ ortzáundià

Zubirik erabiltzen duen azentua adierazteko modua gurera egokituz, honela gelditzen zaizkigu adibideok: 
lan berría, làn berría $\neq$ lanbérria

púska leór $\neq$ puskáleor

góiz aldèra $\neq$ goizáldera

ortz aundía, òrtz aundía $\neq$ ortzàundia

Honen aurrean, galdera hau sortzen zaigu: zein da aldaketa hauen arrazoia? Zein arauk azaltzen ditu? Erantzuna bilatzeko, adibide gehiago bilatu ditugu eta ondorio hauek atera:

Hitz elkartuetan joera bigarren silaban goranzko azentua egotea da. Hitz elkartuaren 1. osagaiak beste azentu bat izan arren, elkarketan patroi honetara egokitzen dela dirudi. Hona hemen adibide batzuk, 1. osagaiaren azentu ezaugarrien arabera:

- 1. osagaia $[+2, \mathrm{~g}]$ denean:

- afári + beréndu > afári-berèndu, basó + urdé > basúrde, begi + luzé > beíluze, mutúr + zuri > mutúrzuri, udá + giro > udágiro

- Salbuespen: basó + áuntz > basàuntz, urdé + áma > urdàma

— Salbuespenaren azalpenerako hipotesia: ó + ó > ò. Beraz: o-ó + ó-o > o-ò-o

- Salbuespen: udá + berrí > udàberrí, garái + aldé > garàikaldé

— Salbuespenerako azalpenik ez

- 1. osagaia $[+1, \mathrm{~g}]$ denean:

- áo + zabál > aó-zabal, dántza + sàio > dantzá-saio, díru + gosé > dirú-gose, kísu + labé > kisúlabe, fiésta + ondòre > festóndore, méta + ziri > metáziri, órtz + makéts $>$ ortzámakets

- Salbuespen: órtz + aundi > ortzàundi, fiésta + àurre > festàurre

- Salbuespenaren azalpenerako hipotesia: aundí eta àurre bereziak dira. àurre azentu markatudun hitzen artean dago eta aundi hitzarekin osatutako beste konposatuak ere irregularrak dira azentuari dagokionez: burú + aundí > burùndi, biótz + aundi > biótzaundi, gáltz + aundi > galtzàundi, ipúrdi + aundi > ipúrdiaundi

- 1. osagaia $[+2, \mathrm{~b}]$ denean:

- arràutza + azál > arráutza-azal, pillòta + pláza > pillóta-plàza

- Salbuespen: sardina + zár > sardintzar, afári + àurre > afalaurré, bazkàri + àurre > bazkàlaurré

— sardintzar salbuespenerako azalpenik ez. àurre-rekin osatutako hitz elkartuez goiko adibidean hitz egin dugu.

- 1. osagaia $[+1, \mathrm{~b}]$ denean:

- kàfe + esné > kàfesné (zhr), kafésne (gzt), kòtxe + kapóta > kotxé-kapòta 


\subsubsection{Hitz elkartuen azentuerarako joera orokorrak}

Hitz elkartuetan joera orokorra [+2] silaban goranzko azentua edukitzea dela esan dugu. Salbuespen batzuk agertu zaizkigu eta, denentzako azalpena aurkitu ez badugu ere, joera nagusia hori dela pentsatzen jarraitzen dugu. Joera hau arau bihurtzeko, honela formula daiteke:

— Hitz elkartuen azentueraren araua: hitz elkartuen azentu nagusia 2. silaban dago. Azentu hau goranzkoa izan ohi da, baina beheranzkoa ere izan daiteke.

Salbuespen gutxi topatu ditugu: gótti-bètti, kàfesné (zhr). Dántza-sàioa entzutea ere ez da arraroa. Adberbioen atalean (4.2.3.) zerrendatutako hitz-elkartuek ere kontraadibide bakarra dute: dèusé(z).

Horretaz gain, beste joera hau dago: hitz elkartuaren 2. osagaiak ere 2. silaban azentua hartzeko joera du hitz elkartu luzeetan (kotxé-kapòta, afári-berèndu) eta 2. silaban beheranzko azentua dutenetan (udàberrí, garàikaldè). 1. azentua goranzkoa edo beheranzkoa izan, alderantzizkoa da 2.a:

- 1. azentua goranzkoa denean, 2.a beheranzkoa da

\begin{tabular}{|l|l|l|l|l|}
\hline$k o$ & txé & $k a$ & $p \grave{o}$ & ta \\
\hline & & & & \\
\hline
\end{tabular}

1. azentua

2. azentua

-1. azentua beheranzkoa denean, 2.a goranzkoa da

\begin{tabular}{|l|l|l|l|l|}
\hline$u$ & $d \grave{a}$ & $b e$ & $r r i$ & $a$ \\
\hline & & & & \\
\hline
\end{tabular}

1. azentua

2. azentua

\subsubsection{Joeren arrazoiak: azentu arauak}

Hitz elkartuen azentu ezarketarako, gainerako hitzetarako deduzitu ditugun azentu arau hauek aplikagarriak direla ikusi dugu:

- Hitzaren 1. azentua ez da 2. silaba baino eskuinerago agertu ohi: ${ }^{21}$ biótz + aundì > biótzaundi, udà + berrí > udàberri

-3 silaba edo gehiagoko hitzak ez dira 1. silaban azentuatu ohi ${ }^{22}$ (H\&L 2008: 342): méta + zirí > metáziri, gàltz + aundí > galtzàundi

${ }^{21}$ Astelén da salbuespen bakarra, oraingoz, eta astélena ere esaten da.

${ }^{22}$ Hauek dira topatu ditugun salbuespenak: yéndetasuna $\mathrm{zhr}$, tzútendemon $\mathrm{zhr}$, zérrengatik, yásotzeko, kónturatu. Denak hitz eratorriak dira. 
Argitzeke gelditzen da zergatik batzuetan 2. silabako azentu hori goranzkoa den eta besteetan beheranzkoa.

\section{Adinaren araberako aldakortasuna}

Atal honetan azentu aldakortasuna bi ikuspegi hauetatik aztertu nahi izan dugu: batetik, egoerak berak gazte nahiz adindunengan eragiten duen hizkuntza aldakortasuna eta, bestetik, Goizuetako hizkeraren aldakortasuna zenbatekoa den esaten saiatuko gara.

\subsection{Gazte eta adinduen hizkera jasoa}

Mikrofonoaren aurrean egoteak sortzen duen ezinegona hitz egiteko orduan nabaritzen da gazte nahiz adindunengan. Eragina berbera da, baina ondorioak ezberdinak batzuengan eta besteengan, bakoitzarentzat modu jasoan hitz egitea ez delako gauza bera. Gazteek hitzak osoagoak, «batuagoak» esaten dituzte, orokorrean, batzuek erdialdeko euskarara jotzeko joera ere erakusten badute ere. Helduen kasuan ez dut nabaritu hitzak osoagotzeko joera hori. Izatekotan, erdialdeko euskarara jotzen dute, hain zuzen ere, beren "estandarra» hori baitzen.

Goizuetako hizkerak, gainerakoek bezala, beste hizkeren eragina du. Garai batean, gaur egun erdialdeko euskara deitzen duguna zen eragin horren motor. Horregatik, lehengo hiztunen joera euskara horretarantz lerratzea izanen zen hizkera jasoa erabili nahi zutenetan. Gaur den egunean, oraindik ere badago joera hori, baina euskara batua lekua hartzen ari da. Egungo hiztun gazteek herritik kanpokoekin edo beren hizkera zaindu behar duten egoeretan hitz egitean, euskara baturanzko joera gehiago dute.

Hala ere, ezin esan denek berdin egiten dutela. Izan ere, bai adinduen artean, bai gazteen artean, denetik dagoela ikusi dugu: poliki eta hitzak osoago ahoskatuz eta azkar eta hitzak moztuz hitz egiten dutenak, bai batean, bai bestean. Nagusiki, beste faktore hauek eragiten dute: izaera lasai edo urduria izatea eta familia edo inguru hurbileko hizkera ohiturak.

Azentuera da modu jasoan hitz egin nahian beste hizkerako ezaugarriak hartzen ditugunean galtzen dugun aurrena. Zaila egiten da hitzak osoago, batuago esaten saiatu eta Goizuetako hizkeraren azentu sistema mantentzea. Zaila da, era berean, azentua nola aldatzen den aztertzea, ezaugarri irristakorra da oso.

\subsection{Goizuetan azentuera zenbat aldatu da?}

Hizkera asko eta azkar alda daitekeen ikergaia da. Hiztunen gaur den eguneko egoeran, fenomeno arrunta da aldaketarena. Goizuetatik (linguistikoki eta geografikoki) gertu dagoen Oiartzunen azentu aldaketa egon da adinduetatik gazteengana, esaterako. Adinduen hizkerak Goizuetako doinuarekin antza handia du eta gazteenak ez, orokorrean. Goizuetan ordea, aldaketa askoz ttikiagoa izan da. Horretarako arrazoi nagusiak hauek dira, nire ustez:

- Goizuetan euskarak garrantzia du, estatusa duen hizkuntza da. Orain gehiago lehen baino. 
— Goizuetan bertako hizkerak garrantzia du. Inguruan hizkera diferenteak egon arren, norberarena mantentzen saiatzea hobeki ikusia dago bestera aldatzea baino (biak egiten diren arren).

— Kanpoko euskaldunek, orokorrean, asko preziatzen duten hizkera da.

Hemen aipatutakoak herriko 80 urtetik gorako bi emakumeren ahotan ere entzun ditugu:

Beste aldaketa men do hizkeran. Euskera, lehengoa ta uaingoa difente al da?

Ez, ez, Goizutan ez. Goizutan itten da lehengo hizkuntza, zaharra. Oań, nik eztikit lotsangatik o zer den,, neskak yoten dia neskame betti. Yoten tzian, e? Oan ya hori attutzen ai da,,. Eta, pasatzen tzuten hillabete bat,, o bi han,, torri honara,, eta hemengo hizkuntza ez ittetikan,, itten tzuten beste hizkuntza hori: No sos? Nongo sa? nola itten da?

Nola?

E? Beste hizkuntza. Guk itten du zeta. Ta haiek berriz, ba, ese. Ya, hemengo ezten bezala,, hizkuntza in. Hori, sartzen ziten itsusi zela hemengoa,,. Guk hemengok, bizi ganak,, ta itten du dena igual, denak.

Ordun zer tzen, gipuzkera o hola?

Bai, Donostin ta Tolosan ta hoitan da beste hizkuntza,., Aranon e hala itten da,, Leitzen e bai,,. Herri guzitan difente da-ta! [...] Hemen lehengo hizkuntza itten da. Zuk [e]z'al tzo hal'itten?

Ta haiek guri, kanpokok guri enteintzen al diute?

Batzuk bai, bestek ez. Batzuk bai. Enteinttu denak. Miño guk zakartxio hitzeiñen du. Hal'iduitzen tzit niri ta saten' $[d u]$ te ezetz.

Gotzon Garatek ze saten tzun?

Oi. Hemengo hizkuntza zela,, goxoa.

Zakarra ez.

Ez, ez, ez, ez. Oso goxoa. Ta zaharranatakoa, e? Zaharranatakoa, hizkuntza. Hori askok sateun'te.

Oain, Goizutako hizkuntza asko estimatzen da, toki askotan. Goizutako hizkuntza politta dela esaten dute, askok.

Hizkuntzaren estatus arrazoiez gain, arrazoi demografikoak daude:

— Ez da egon Euskal Herriko herri handiagoetan egon den aldaketa demografikoa (Oiartzunen bai, adibidez). 
- Goizuetan egon den demografia aldaketa biztanleen jaitsiera izan da. Honek lehengoari (egoera hobeari) eutsi nahi izatea azal dezake. Lehengo horri eusteko modu bat da lehengo ohiturei eta betiko hitz egiteko moduari eustea.

Bill Haddicanen lanak ere antzeko faktoreei egiten die erreferentzia Oiartzungo hiztunek euskara batuaren aurrean, bere hizkerari eusteko dituzten arrazoiak azaltzean (2007: 686):

I would like to suggest that the rise in dialect loyalty in Oiartzun - the sense among many Oiartzuners that the local dialect needs to be «defended" from Batuais partly reaction to changes in town life discussed above, and in particular to a perceived weakening of community identity and participation in colective life. That is, Oiartzuners' nostalgia for traditional practices and more dense local social networks is plausibly manifested in what they say about language in Oiartzun (and, as I will argue below, in linguistic practice).

Hizkera aldatu egin da, baina ez modu traumatiko batean: gazte eta adinduen artean ez dago ulertzeko zailtasunik eta dagoen aldaketa, ez da oso handitzat hartu ohi. Iritzi ezberdinak daude, dena den. Batzuk diferentzia handia dela esaten dute, baina aldea azaltzeko esanez gero, garai baten erabiltzen ziren hitzak galdu egin direla esaten dute: orduko lanak, tresnak, animalien adin eta egoera diferenteak etab. izendatzeko erabiltzen zirenak.

Gure iritziz, gainerako hizkeretan gertatzen ari diren aldaketak kontuan hartuta, Goizuetan hizkuntza bariazioa ttikia izan da. Orokorrean, ez da eten nabaririk izan hiztunentzat eta ez da modu traumatikoan bizi. Dena den, belarria erne jarriz gero, alde hauek nabaritu ahal dira:

\section{Lexikoari dagokionez:}

Aldaketa lexikoan egon da, nagusiki: helduek baserri munduarekin edo lehengo ofizioekin lotutako lexiko zabalagoa erabiltzen zuten. Gazteek, berriz, erdarakada gehiago erabiltzen dituztela esaten da. Arlo batzuetan hala da, baina euskara batuko hitzak helduek baino gehiago erabiltzen dituzte: telebista, irratia, egunkaria...

\section{Doinuari dagokionez:}

1. Helduek azentuzko gorabehera handiagoak egiten zituzten. Joera nagusia hori da: gaur den eguneko gazteek ez dute hain «kantari» hitz egiten. Dena den, gazteen artean ere badaude gorabehera berdinekin hitz egiten dutenak.

2. Aditzen azentueran aldaketa bat nabaritu dugu: helduek aditz laguntzaileari azentua mantentzeko joera erakusten dute eta gazteek 2. silaban azentuatu ohi dute:

- Helduek: dútenak, tzútena, deitzen tziten, éztiàlako

- Gazteek: dutènak, tzuténa, deitzen tzitén, eztiálako

- Joera hori bada ere, gazte batzuek bi aldaerak erabiltzen dituzte: ditela / ditéla. Hona 26 urteko mutiko bati grabatutakoa: 
Baserritarran ta herritarran euskera difentea al da, zure ustez?

Nik uste, pixko gehio... azento gehio zetzen dutela, esajeratzen dútela. Tonua fuerteo maten dítela. Segun ez? Nik uste ez dela baserrikoa ta zea, herrikoa baitare. Gero famili batzutatik bestera re difentzia badola sain nuke nik. Famili batzutan nabaitzen da azento gehio maten ditéla ta beste batzuk garbio hitzein o... zeago, lasaio bezala o... Beste batzuk aurogo hitzeitten dute. Hori nik eztikit zeren arabera izain den, mińo... Herri ttikia da miño, badia zea difentek. Hizkera difenteko o hitzeitteko forma difentek.

Gainerako gazteei ez zaie konturatu gabe pasatzen eta arraro (edo gaizki) ari direla esaten diete.

— Adinduek ere bi aldaerak eman izan dituzte: ez génun, ez genún. 80 urtetik gorako beste emakume honen ahotan:

\section{Adibidez difentzia zertan?}

Difentzia,, denen. Gauzakiń, yatekon,, yantzitzekon. Yantzitzekon e, ez génun izaten arropik e ta! Bata bestenakin-ta ibiltzen giñan! Ez kénun izaten. Ta erosteko re ez kenún! Diruik etzen!

3. Aldakortasuna erakusten duten hitz gehiago daude: Berá / Bèra, hizkera / hizkèra, bàzkari / bazkàri, bàzkaldu / bazkàldu, létxua / letxùa, zintzatu / zintzàtu, kàfesne / kafésne, árpi / arpéi, laúndu / láundu, púre / purè, kanbiok / kànbiok...

Lehen aldaera batez ere helduek esaten dute eta bigarrena gazteek. Azken bi pareetan adinarekin ez dugu loturarik topatu.

Ondorio nagusia, dena den, goian esandakoa da: aldaketak aldaketa, azentu patroi berbera erabiltzen dute Goizuetako heldu eta zaharrek.

\section{Aurkikuntza eta ondorio nagusiak}

Lanean zehar azaldu diren aurkikuntza eta ondorio nagusiak bukaeran bildu nahi izan ditugu. Hona hemen:

Bi goranzko azentuk ezin dute elkarren jarraian egon. Horrelako kasuetan, lehen azentua galtzen da. Adib.: gizón + ttikia > gizon ttikia, itxé + ttíkia > itxe ttíkia.

Bi beheranzko azentuk ezin dute elkarren jarraian egon. Bi silabatako tartea behar dute elkarren artean. Kasu hauetan, lehen azentua goranzko bihurtzen da. Adib.: mài + bàtzuk > mái batzuk, mài + horik > mái horìk.

Aditzen jeneralizazioa. Azentu aldaketa duten aditzek azentua azken silaban dute (salbuespen asko "memoria historikoaren bidez» azaltzen dira). Adib.: *áittu, ài, àitzen (aditu). Memoria historikoarena honegatik diogu: abixtu, abix, abixten (abisatu) 
adibidean, abix, abixten espero genezakeen, baina ez da horrela gertatzen, oinarrian dagoen hitzak jatorrizko azentuera gorde duelako (abixatu > abixtu).

Galdegaiaren araua. Aditza ez bada galdegaia, goranzko azentua du; galdegaia bada, beheranzkoa ((1) eta (3) multzoko aditzen kasuan)

Yéndek aintzen al do? Ez, diruk áintzen do.

Diruk ezto déustako balio! Ez, diruk àintzen do.

Eulia airátu al da? Ez, txoría airátu da.

Txoria hemen al da? Ez, txoría airàtu da.

Hitz elkartuen araua. Hitz elkartuen azentu nagusia 2. silaban dago. Azentu hau goranzkoa izan ohi da, baina beheranzkoa ere izan daiteke.

- 1. azentua goranzkoa denean, 2.a beheranzkoa da:

\begin{tabular}{|l|l|l|l|l|}
\hline$k o$ & txé - & $k a$ & $p \grave{o}$ & ta \\
\hline & & & & \\
\hline
\end{tabular}

1. azentua

2. azentua

- 1. azentua beheranzkoa denean, 2.a goranzkoa da:

\begin{tabular}{|l|l|l|l|l|}
\hline$u$ & $d \grave{a}$ & $b e$ & $r r i$ & $a$ \\
\hline & & & & \\
\hline
\end{tabular}

1. azentua

2. azentua

\section{Bibliografia}

Azkue, R. M., 1932, «Del acento tónico vasco en algunos de sus dialectos», Euskera 4: 3-50. Elexpuru, J. M., 2004, Bergara aldeko hiztegia. Bergara: Bergarako Udala.

Etxebarria, J. M., 1988, Zeberio haraneko euskararen azterketa etno-linguistikoa. Bilbo: Deustuko Unibertsitatea.

Gaminde, I., 1998, Euskaldunen azentuak. Bilbo: Labayru Ikastegia.

Haddican, B., 2007, «Suburbanization and language change in Basque», Language in Society 36: 677-706.

Hualde, J. I., 1997, Euskararen azentuerak. Bilbo: Euskal Herriko Unibertsitatea.

—, 2007, «Historical convergence and divergence in Basque accentuation». In T. Riad eta

C. Gussenhoven (arg.), Tones and tunes: Typological studies in word and sentence prosody. Berlin: Mouton de Gruyter.

- eta Lujanbio, O., 2008, «Goizuetako azentuera». In X. Artiagoitia eta J. A. Lakarra (arg.), Gramatika Jaietan: Patxi Goenagaren Omenez. Gasteiz: UPV/EHUko Argitalpen Zerbitzua (341-358). 
— eta —, 2009, "Goizuetako azentuaz zerbait gehiago: oharmena». In Gomez, R.; Etxepare, R.; Lakarra, J. A. Beñat Oihartzabali gorazarre - Festchrift for Bernard Oyharçabal. ASJU 43 (1-2): 485-502.

—, - eta Torreira, F., 2008, "Lexical tone and stress in Goizueta Basque», Journal of the International Phonetic Association 38 (1): 1-24.

—, - eta Zubiri, J. J., 2010, "Goizueta Basque», Journal of the International Phonetic Association 40: 113-128.

Irurtzun, A., 2006, «Stress on Accent; Errenteria Basque Revisited». Artxiker.

Jacobsen, W., 1972, «Nominative-ergative synchretism in Basque», ASJU 6: 67-109.

Juaristi, P., 2003, Gizarte ikerketarako teknikak: teoria eta adibideak. Leioa: Euskal Herriko Unibertsitatea.

Mitxelena, K., 1972, «A note on old labourdin accentuation», ASJU 6: 110-120.

—, 1976, "Acentuación alto-navarra», FLV 8: 147-162.

—, 1977, Fonética Histórica Vasca. 2. arg. Donostia: Gipuzkoako Foru Aldundia.

Olano, M., 2005, Aio, Leitze! Leitzako euskararen hiztegia. Etnografia, corpusa, dialektologia. Leitzako Udala: Nafarroako Iparraldeko Euskara Mankomunitatea.

Salaburu, P., 2005, Baztango mintzoa: gramatika eta hiztegia. Iruñea: Nafarroako Gobernua, Hezkuntza Departamentua.

Sarasola, I., 2007, Euskal hiztegia. Donostia: Elkar.

Zuazo, K., 2013, Mailopeko euskara. Bilbo: UPV/EHUren Argitalpen Zerbitzua.

Zubiri, J. J., 2000, «Arano eta Goizuetako hizkera» in Zuazo, Koldo (arg.), Dialektologia gaiak. Gasteiz: Arabako Foru Aldundia.

- eta Perurena, P., 1998, Goizueta eta Aranoko hizkerak. Iruñea: Nafarroako Gobernua, eta Goizuetako eta Aranoko Udalak.

Oihana Lujanbio

«Luis Villasante» Ikergunea - Euskaltzaindia,

Tolare baserria, Almortza bidea, 6

20018 DONOSTIA

Tel.: 943428050

olujanbio@euskaltzaindia.eus 